\title{
A Political Strategy for the Liberation of Women: Socialist Feminist Political Practice
}

\author{
by
}

Jenna R. Amirault

A thesis submitted to the Faculty of Graduate and Postdoctoral Affairs in partial fulfillment of the requirements for the degree of

Doctor of Philosophy

in

Sociology with a Specialization in Political Economy

Carleton University

Ottawa, Ontario

(C) 2019

Jenna R. Amirault 


\section{Abstract}

This dissertation examines socialist feminism as it developed as a political force in English-speaking parts of Canada, especially Toronto, from the 1960s - 1980s. This project contributes to documenting, summarizing, and analyzing socialist feminist activity, with particular attention devoted to organizational forms and methods. The legacy of socialist feminism is remembered as a disinclination towards parties, leadership, and organization. In reviewing the history of socialist feminism, I show that this is not an accurate portrayal of the movement. Instead, there were heated debates about the best strategies for achieving the goals of the movement.

Drawing on archival research, interviews and secondary sources, I look at what practices emerged from the development of socialist feminism that can inform contemporary projects for women's liberation. Socialist feminists rooted their analysis of women's oppression in relation to capitalist production and economic structures. Their political work on reproductive rights, childcare, housework, equal pay, anti-free trade, labour, and anti-war were all rooted in an understanding of how capital structured the lives of people. Throughout this dissertation, I'll show how this analysis helped strengthen the political work of the women's movement and political organizations on the Left. I also examine socialist feminism's relationship to communist and socialist organizing by women and around the woman question historically, alongside the developments in class struggle in Canada and the ideological and political divisions in the socialist Left.

Reflecting on socialist feminism from our vantage-point today, I argue that a reconsideration of the role of the socialist political party is needed. A modern socialist 
left must be conscious of what tools cannot be discarded, or are indeed most critical, if it hopes to organize people in the thousands and millions required to bring about transformative, revolutionary change. 


\section{Acknowledgements}

There are many people involved in the writing of a dissertation, whether through feedback, guidance, encouragement, administration, and/or emotional support.

My sincerest thanks to my advisor, Dr. Justin Paulson, who has been my advocate throughout this journey. I'm lucky to be one of several students who has benefitted from your wisdom, kindness, and support. None of this would have been possible without you and I am endlessly grateful. I cannot imagine a better mentor.

I would like to express my deepest appreciation to my committee members Dr. Susan Braedley and Dr. Rebecca Schein. Because of your time, encouragement, and thoughtful feedback this dissertation is much stronger. Thank you.

I am also grateful to Dr. Aaron Doyle and Dr. Jackie Kennelly who stepped in as committee members during my comprehensive exams and provided feedback for this project. Also, special thanks to Dr. Jim Sacouman for being a dear friend and believing I could do this in the first place.

Thank you to the administrative staff in the Department of Sociology and Institute of Political Economy: Paula Whissell, Kimberly Séguin, Stephanie LeBlanc, Darlene Moss, Donna Coghill, and Patricia Lacroix.

Deepest gratitude to my dear friends and colleagues: Michael Bueckert, Eloy RivasSanchez, Mikayla Sherry, Sarah Rodimon, Max Chewinski, Melissa Conte, and Jessica Azevedo. To my cheerleaders and friends: Shane Sadorski, Danielle Pierce, Scott Lewin, and Kevin O'Meara. Thank you to my fiancé, Sam Heaton, without you this project would have likely fallen to the wayside. Thanks for believing in me, for your help, and your brilliance. To my mom whose love, strength, and sacrifices continue to inspire.

Finally, thank you to all those who agreed to be interviewed for this project. Your time and kindness are greatly appreciated. I hope that this dissertation sheds light on some of your past organizational efforts and that a new generation of activists can learn from your struggles. 


\section{Table of Contents}

ABSTRACT II

ACKNOWLEDGEMENTS IV

TABLE OF CONTENTS V V

LIST OF ABBREVIATIONS VI

TIMELINE OF ORGANIZATIONS VII

CHAPTER 1: INTRODUCTION 1

1.1 INTRODUCTION AND CHAPTER OUTLINE

1.2 WhAT IS SOCIALIST FEMINISM? 6

1.3 SUMMARY OF KEY FINDINGS

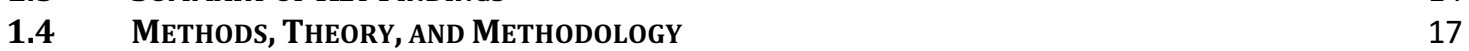

1.5 FLASHPOINT INTERVENTIONS AND KEY DEBATES 24

CHAPTER 2: EARLY COMMUNIST AND SOCIALIST WOMEN'S RESISTANCE $\quad 47$

2.1 CANAdA's INDUSTRIAl AdVANCEMENT AND EARly Socialist ORGANIZING 49

2.2 The RuSSIAN REVOLUTION AND LENINISM IN CANADA 64

2.3 DEPRESSION-ERA ORGANIZING AND THE FOUNDING OF THE CCF

2.4 World War II ANd its Aftermath: Changing VieWs of Stalin 89

CHAPTER 3: POLITICAL DIVISIONS IN THE 1960S LEFT AND WOMEN'S MOVEMENT 96

3.1 DIVISIONS BETWEEN THE NEW LEFT AND OLD LEFT 96

3.2 LIBERAL, RADICAL, AND SOCIALIST FEMINISMS 102

\begin{tabular}{ll}
3.3 & SOCIALIST FEMINISTS AND ACADEMIA \\
\hline
\end{tabular}

CHAPTER 4: THE POLITICAL ACTIVISM OF SOCIALIST FEMINISTS 122

4.1 ABortion ANd ReProductive HeALTH 122

4.2 INTERNATIONAL WOMEN'S DAY AND THE IWD COMMITTEE 131

$\begin{array}{llr}4.3 & \text { ANTI-IMPERIALISM AND ANTI-WAR } & 140\end{array}$

4.4 RElation to Anti-RACist AND ANTI-Colonialist ORgANIZING 150

$\begin{array}{llr}4.5 & \text { LABOUR ISSUES } & 163\end{array}$

$\begin{array}{llr}4.6 & \text { FREE AND UNIVERSAL DAYCARE } & 174\end{array}$

$\begin{array}{llr}4.7 & \text { Positions ON WAgES For Housework CAMPAign } & 181\end{array}$

CHAPTER 5: CONCLUSION 190

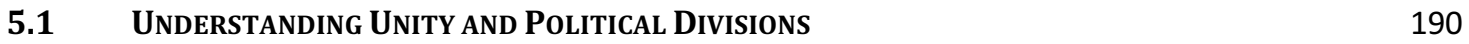

$\begin{array}{llr}\text { 5.2 STRUCTURELESSNESS, CONSENSUS, AND LEADERSHIP } & 191\end{array}$

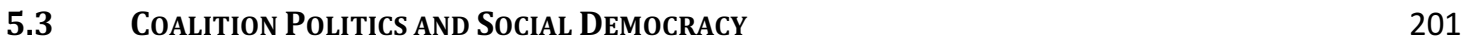

$\begin{array}{ll}5.4 & 208\end{array}$

$\begin{array}{llr}5.5 & \text { Reconsidering the Political Party } & 214\end{array}$

$\begin{array}{llr}5.6 & \text { CONCLUSION } & 217\end{array}$

$\begin{array}{lr}\text { APPENDIX } & 220\end{array}$

$\begin{array}{lr}\text { WORKS CITED } & 224\end{array}$ 


\section{List of Abbreviations}

$\begin{array}{ll}\text { AUCP(b) } & \text { All-Union Communist Party (Bolsheviks) } \\ \text { CACSW } & \text { Canadian Advisory Council on the Status of Women } \\ \text { CCF } & \text { Cooperative Commonwealth Federation } \\ \text { CLC } & \text { Canadian Labour Congress } \\ \text { CSL } & \text { Canadian Socialist League } \\ \text { CPC } & \text { Communist Party of Canada } \\ \text { CPUSA } & \text { Communist Party of the Unite States of America } \\ \text { CPGB } & \text { Communist Party of Great Britain } \\ \text { DSA } & \text { Democratic Socialists of America } \\ \text { GMR } & \text { Groupe Marxiste Révolutionaire } \\ \text { LSA } & \text { League for Socialist Action } \\ \text { NAC } & \text { National Action Committee on the Status of Women } \\ \text { NDP } & \text { New Democratic Party } \\ \text { NWRC } & \text { Native Women's Resource Centre } \\ \text { OCAC } & \text { Ontario Coalition for Abortion Clinics } \\ \text { OFL } & \text { Ontario Federation of Labour } \\ \text { ONDP } & \text { Ontario New Democratic Party } \\ \text { OPSEU } & \text { Ontario Public Employees Service Union } \\ \text { OWW } & \text { Organized Working Women } \\ \text { RCMP } & \text { Royal Canadian Mounted Police } \\ \text { RGR } & \text { Rebel Girls' Rag } \\ \text { RMG } & \text { Revolutionary Marxist Group } \\ \text { RWL } & \text { Revolutionary Worker's League } \\ \text { SDP } & \text { Social Democratic Party } \\ \text { SUPA } & \text { Student Union for Peace Action } \\ \text { SPNA } & \text { Socialist Party of North America } \\ \text { SWW } & \text { Saskatchewan Working Women } \\ \text { TSFA } & \text { Toronto Socialist feminist Action } \\ \text { TWB } & \text { Toronto Women's Bookstore } \\ \text { USSR } & \text { Union of Soviet Socialist Republics } \\ \text { IODE } & \text { International Order of the Daughters of Empire } \\ \text { ILO } & \text { International Left Opposition (Trotskyist) Canada } \\ \text { IS } & \text { International Socialists } \\ \text { IWD } & \text { International Women's Day } \\ \text { IWDC } & \text { International Women's Day Committee } \\ \text { VOW } & \text { Voice of Women } \\ \text { VWC } & \text { Vancouver Women's Caucus } \\ \text { WAVAW } & \text { Women Against Violence Against Women } \\ \text { WLL } & \text { Women's Labour League } \\ & \\ & \\ \text { NWA } & \end{array}$




\section{Timeline of Organizations}

\begin{tabular}{|c|c|}
\hline $1898-1905$ & Canadian Socialist League \\
\hline $1905-1925$ & Socialist Party of Canada \\
\hline $1911-1914$ & Socialist Party of North America \\
\hline 1921 - present & Communist Party of Canada \\
\hline 1932 - present & $\begin{array}{l}\text { Co-operative Commonwealth Federation, later } \\
\text { New Democratic Party }\end{array}$ \\
\hline $1961-1977$ & League for Socialist Action \\
\hline $1964-1967$ & Student Union for Peace Action \\
\hline $1968-1971$ & Vancouver Women's Caucus \\
\hline $1971-2007$ & $\begin{array}{l}\text { National Action Committee on the Status of } \\
\text { Women }\end{array}$ \\
\hline $1973-1977$ & Revolutionary Marxist Group \\
\hline $1976-1990 s$ & Organized Working Women \\
\hline $1977-1990$ & Revolutionary Worker's League \\
\hline $1978-1987$ & International Women's Day Committee \\
\hline 1982 - present & Ontario Coalition for Abortion Clinics \\
\hline $1987-1992$ & Toronto Socialist Feminist Action \\
\hline
\end{tabular}




\section{Chapter 1: Introduction}

\subsection{Introduction and Chapter Outline}

With the end of the Cold War, many of the left-wing and progressive movements that once flourished were supposed to be consigned to the past. The "end of history" narrative declared Marxism in particular - in the academy, in governments, and in the streets - to be defeated. Among the casualties of this international development were not just the once-powerful communist parties but much of the spectrum of Marxist and socialist thinking and action around which tremendous activity was concentrated in the previous decades. This loss has been heavily felt in the politics of Canada and much of the world, where bold demands for revolution and transformational reforms were largely supplanted by neo-liberal and business-oriented "solutions." At the same time, new generations of activists, women, and workers are putting socialism back on the political map. In a previous high point of socialist activity from the 1960s-1980s, organizational strategies and viewpoints were as numerous as the era's fractured political groupings. What such movements had to say about questions of organization, leadership, and coalitions, still unanswered by today's activists is not insignificant.

This dissertation is a work of historical sociology that focuses on how socialist feminism developed as a political force in English-speaking Canada, especially Toronto. This project contributes to documenting, summarizing, and analyzing some of this activity, in particular a prominent strand of activism in the 1960s - 1980s, socialist feminism, how it answered some of these questions, and how these answers 
hold water today. It is my contribution to the historical sociology of socialist activism in Canada following in the footsteps of Meg Luxton, Joan Sangster, Judy Rebick, Linda Briskin, Susan Ferguson, and Heather Jon Maroney. Through secondary research, archival work and interviews with prominent movement participants, I try to make sense of experiences in organizing, in the context of the often-forgotten history of socialist women's struggles. In doing so, I consider what practices emerged from the development of socialist feminism in Toronto that can inform contemporary projects for socialism and women's emancipation. In particular, I consider issues and debates around the role of leadership, coalitions, social democracy, and ideological unity. Socialist feminism has been a source of productive debate about these organizational questions. In attempting to challenge both capitalism and patriarchy, socialist feminists also tried to synthesize socialism and feminism in a way that brought important insights from the movements of the day. As I explored these debates, it became clear that socialist feminist history had to be situated within the broader political landscapes they were navigating - namely, in relation to the ideological and organizational histories and proclivities of the Old Left, New Left, and broader women's movement. In that vein, it was important that this dissertation document the political alliances socialist feminists built and maintained, and how this shaped their political practice. Additional, exploring socialist feminism's relationship to communist and socialist organizing by women and around the woman question historically in Canada points to important, if little-known forerunners with their own views on organizational questions. 
In this introductory chapter, I provide a definition of socialist feminism, discuss the existing gap in the literature, summarize my findings, and provide the methods, methodology and theory for this project. The literature review focuses on what organizational practices are ascribed to socialist feminists and how these organizational practices are presented. I also explore how the relationship between socialist feminists and the larger socialist movement is presented.

In Chapter 2, I consider the longer history of women's labour activism and socialist women's struggles in Canada. Women's struggles in Canada are often portrayed as having been born in the tumultuous 1960s, yet there is a political, social, and economic context from which they emerged, and the earlier socialist struggle paved the way on many issues even when the direct link did not remain. In highlighting accounts of women's resistance during both the pre-World War I and the Cold War periods, I provide an historical review of socialist contributions to the women's movement, leading up to the development of socialist feminism as a distinct political project. This history lays the groundwork for understanding socialist feminism as it relates to the larger socialist movement including the continuities and discontinuities with this earlier period in regard to political practice. Early socialist women's struggles anticipate some of the discussions and debates in which socialist feminists engaged beginning in the 1960s, including strategies for women's liberation and how to view women's status in Soviet/socialist countries. Understanding how this context informed (or did not inform) the women's movements from the 1960s onward helps to situate these later movements within Canada's overall political and economic development. 
In Chapter 3, I focus on the various political divisions that socialist feminists navigated in the socialist left, women's movement, and academia. Although socialist feminists owed a debt to earlier socialist women, they often identified with the New Left of the 1960s-1970s. What did "New Left" really mean, and what, if anything, does it signify about the organizational forms of that time? To a surprising degree, socialist feminists inhabited organizing spaces reflective of the Old Left and New Left alike and took part in debates on the merits of these forms. What becomes clear is that the divisions between socialist feminists, leftists, liberal feminists, and radical feminists - and between academics and activists -- reflect this period's divisions in politics more broadly, i.e., between liberalism, social democracy, radical feminism, and Marxism (including academic Marxism, Marxist-Leninism, Trotskyism, and Maoism). Within the women's movement, socialist feminists squared off against liberal and radical feminists whose understandings of women's oppression differed from their own and made working together difficult. Additionally, while many socialist feminists were introduced to socialist and feminist ideas in university, academia, some argued, had limited opportunities for organizing.

In Chapter 4, I provide an historical review of socialist feminist political activity. I focus on seven areas of activism: abortion and reproductive rights, International Women's Day, anti-imperialism and anti-war, anti-racism, labour issues, free and universal daycare, and maternity leave. I also examine socialist feminists' relationship to the Wages for Housework Campaign, a campaign that sought to procure wages for women performing unpaid labour in the home. To enrich these accounts, I draw on archival work and interviews with activists who 
participated in historical socialist feminist and socialist movements. My conversations with socialist feminists shed light on how they organized around these issues, the political alliances they formed, and their ultimate goals.

In Chapter 5, I offer an analysis of socialist feminists' organizational practices and strategies, arguing that the contemporary women's and socialist movements would benefit from a reappraisal of leadership and anti-party positions. Socialist feminists operated in a context in which New Left forms of organizing relied on concepts such as coalition-building, consensus-based decision-making, decentralization, and prefiguration. Building on the discussion from Chapter 3, I show how these politics were shaped by women's organizing experiences in both the Old and New Left. Women desired to move away from structures that they felt silenced their voices, ignored their issues and ideas, and kept them from becoming leaders in several movements and organizations. Hierarchical and leader-based organizing were often conceptualized as "male organizational forms." This idea of male-centric versus feminist organizational structures was originally conceived by radical feminists but was adopted into some socialist feminist analysis. These principles created a division amongst socialist feminists who adhered to decentralization and those who grew critical of it. This split is well-documented in Rebel Girls' Rag, the publication of Toronto Socialist feminist Action (TSFA). I argue that the fate of the socialist feminist movement, and the political developments that accompanied it suggest that these innovative forms of organizing could exacerbate the very problems they set out to solve and may not be well-suited to large-scale movements. Some 
socialist feminists' own critiques and reflections showed insight into these problems, and preceded disintegrations in the movement.

\subsection{What is Socialist Feminism?}

Defining socialist feminism proved to be a difficult starting place for this project. This difficulty was acknowledged from the beginning by socialist feminists themselves. Meg Luxton, for example, suggested that the definition be kept "as open and fluid as possible." ${ }^{1}$ Similarly, Brenner (2014b) defines socialist feminism "very broadly - to include all feminists (whether or not they would identify with the label) who see class as central, but would not reduce relations of power and privilege organized around particular identities (gender, sexuality, race/ethnicity, nationality) to class oppression" (n.p.). This diversity in opinions and perspectives within socialist feminism led me to struggle with what could be said about socialist feminism as a distinct political movement. As such, I have tried to be cautious and nuanced in my characterizations.

There are various interpretations of socialist feminism's lineage. Some see socialist feminism stretching back to the work of $19^{\text {th }}$ and $20^{\text {th }}$ century communists. Ian McKay (2005), for example, sees socialist feminism developing "from the 1880s to the 1970s" (85). Similarly, Debbie Field argues that Alexandra Kollontai and Rosa Luxemburg could be thought of as early socialist feminists and that Field's generation "re-found that history." ${ }^{2}$ Kollontai and Luxemburg never self-identified as socialist feminists, and both criticized feminism as a bourgeois ideology, but their political

\footnotetext{
${ }^{1}$ Meg Luxton, interview with author, July 19, 2018.

${ }^{2}$ Debbie Field, interview with author, November 8, 2018.
} 
work is seen by some to align with socialist feminist goals. This is the case in part because Kollontai and Luxemburg both identified organizing working-class women for socialism as an important part of revolutionary struggle. ${ }^{3}$ However, to label these two socialist feminists may be a case of "historical projection," a transference of later ideas to political actors of an earlier period. Notably, feminism, in the $19^{\text {th }}$ and early $20^{\text {th }}$ centuries, was not the politically and ideologically diverse movement it is today. It was a largely bourgeois-led movement against which communist women struggled. Kollontai, Luxemburg, Clara Zetkin, and other communist women did not embrace that period's feminism nor try to develop a "Marxist feminism," but saw themselves as communists.

Others (Gordon 2013, Dixon 1977) see socialist feminism as a political trend within the New Left movements emerging in the late 1960s and early 1970s. In this conception, socialist feminism is identified in contrast to the socialist activism and politics of the Old Left of the 1920s - 1950s. This periodization has the benefit of locating the emergence of the concept with the emergence of the term, but it is not without its own flaws. The labelling of socialist feminism in Canada as a movement of the New Left excludes the activism of socialists in various Old Left formations like the Communist Party of Canada (CPC), arguably Old-Left Trotskyist organizations, and

\footnotetext{
3 In The Social Basis of the Women's Question, Kollontai (2006 [1909]) argued that working-class women should abandon the bourgeois feminist movement and its "delusions" about a "united movement" and instead organize in the proletariat movement "against the economic enslavement of the working-class" (n.p). In "Women's Suffrage and Class Struggle" Luxemburg (2003 [1912]) argued that proletariat women can only find salvation in socialism and that suffrage would "immensely advance and intensify the proletarian class struggle" hastening "the coming of the hour when the present society falls in ruins under the hammer strokes of the revolutionary proletariat." In each case, these women argue not for the women's movement but for women's participation in the movement for the proletarian class. For them, this meant organizing in the Communist Party to achieve socialist revolution.
} 
then-Maoist groups like the Communist Party of Canada (Marxist-Leninist) (CPCML). ${ }^{4}$ Some socialist feminists interviewed for this project who organized outside of these organizations labelled women in these organizations as socialist feminists because of their active participation as socialists in the women's movement. In this understanding of the term, socialist feminism is not based on membership in a particular group, and, as Luxton suggests, the definition is kept as open and fluid as possible. Among those belonging to Old Left organizations that persisted into the 1970s, Trotskyists were most comfortable identifying as socialist feminists, while others did not adopt the label themselves. Elizabeth Rowley, long-time activist and current leader of the CPC, distanced herself and other party women from the term, saying,

when the term first became popular, my own view was, and I think a lot of communist women thought, we identify with communism...[though] within the women's movement we certainly supported the idea that women's oppression was linked to capitalism and the solution on that large scale is socialism. ${ }^{5}$

While I was unable to interview anybody from the CPC (ML), there is no indication of the organization embracing the term socialist feminism. However, Peggy Morton, who regularly publishes articles in the CPC (ML) newspapers, authored and coauthored texts that are now considered foundational to socialist feminism in Canada. As a result, whether to label members of the CPC, CPC (ML), and similar organizations

\footnotetext{
${ }^{4}$ Among those interviewed, there was disagreement about whether the Trotskyist organizations of the time, which had roots in the movement of Leon Trotsky's followers in the 1930s and 40s, could be called Old or New Left. This is further discussed in Chapter 2.

${ }^{5}$ Elizabeth Rowley, interview with author, January 4, 2019.
} 
as socialist feminists was not a foregone conclusion. In the end, doing so cannot be justified for the reason that "socialist feminism" was never espoused by their organizations nor did it become consciously adopted within their ranks. While some of the work done by women in these organizations aligned with socialist feminist political analysis, retroactively applying a label that such activists would have likely rejected at the time is questionable. Likewise, there were and are significant positions that these activists do not share with those calling themselves socialist feminists.

Given the considerations discussed above, this dissertation understands socialist feminism as a political movement that developed in the late 1960s and early 1970s. Socialist feminism was influenced in its beginnings by vibrant new social movements fighting against racism, patriarchy, imperialism, and war. Socialist feminists had important commonalities with late $19^{\text {th }}$ and early $20^{\text {th }}$ century communist women organizers, namely the belief that women were important players in the development of socialism, and that socialism was integral to the full development of women's rights. But socialist feminism was distinct in many ways including its willingness to take up New Left organizational methods.

In the context of the women's movement, part of what made socialist feminism unique was that it developed alongside radical feminism. Radical feminism, as a new strand of activism in the 1960s and 1970s, argued that the failures of the left were due to the patriarchal nature of its male leaders and its organizational structures (Willis 2014 [1984]: 231). Radical feminists argued that "yet so long as sexist power relations exist there will be a need for an autonomous, specifically feminist women's movement" (Willis 2014 [1984]: 254). Furthermore, radical feminism took as its 
perspective that "all men oppress women, and collectively do so deliberately for their own collective gain" (Whetmore 2014: 2). They argued that women's subordinate position in society was transhistorical - in other words, a given under capitalism, socialism, or any other existing social formation (Douglas 1980; Daly 1978; Dworkin 1974; Firestone 1970; MacKinnon 1989). Socialist feminists criticized radical feminists for turning to "biology to find the roots of women's oppression" (Whetmore 2014: 3). They "took up the necessary polemic against radical feminism, arguing that men were not the enemy and that locating women's oppression simply in biological differences...failed to account for the fact that women's oppression...took place in the context of capitalist social and economic relations" (Louie and Burnham 1985: 15). In the face of growing radical feminist and liberal feminist movements, socialist feminists boldly asserted that a class analysis was essential to understanding women's oppression. However, over time socialist feminists came to adopt some facets of radical feminism, including aspects of its analysis of patriarchy (Vogel 1989) and, later, some of its analysis of hierarchy (Luxton 2001; Egan 1987; McKay 2005; Brenner 2014; Gordon 2013). In response to radical feminists, some socialist feminists developed a "dual systems theory" of oppression arguing for a synthesis between Marxism and radical feminism which posited that patriarchy and capitalism worked in tandem to oppress women (Young 1980). It was radical feminists' interventions and participation in movements like International Women's Day in Toronto and the National Action Committee that led to socialist feminists having to contend with their ideas. 
Socialist feminism's economic analysis of women's oppression was heavily influenced by Marxism. However, it would be a mistake to say that all socialist feminists were Marxists. Many did not support Marxism or its call for revolutionary social change. Socialist feminism can thus be divided into at least two different camps, in this case: revolutionary and social-democratic. Carolyn Egan identified and explained these differences in an interview:

There are a lot of people that would identify as socialists like social-democrats who may or may not see themselves as Marxists...It's just a slightly different ideological view, we both see capitalism as a problem and the oppression of women, racial oppression, and homophobia. ${ }^{6}$

The term Marxist-feminist was sometimes used in place of socialist feminist by women who more closely adhered to a revolutionary perspective. However, more often than not, the terms were used interchangeably in Canada. Socialist feminists from these differing persuasions had little trouble working together, because their work largely focused on specific campaigns and demands. Coalition and movementbuilding were prioritized over debates about revolutionary versus non-revolutionary or reformist conceptions of social change. Thus, in Canada as in the US, contemporary writers pointed out that "the base of socialist feminism overlaps considerably with that of social democracy and exhibits many of that trend's social characteristics" (Burnham and Louie 1985: 18).

A shared viewpoint of socialist feminists of both revolutionary and socialdemocratic persuasions was criticism of existing socialism, namely, socialism as

\footnotetext{
${ }^{6}$ Carolyn Egan, interview with author, October 1, 2018.
} 
established in the Soviet Union, Eastern Europe, and China. While the underlying logic may have been Trotskyist, social-democratic, or left-socialist, socialist feminists largely saw these societies as degenerated forms of socialism which amounted to dictatorship and totalitarianism. This led many to likewise reject Leninism and its organizational forms, although this was not always the case for those in Trotskyist groups. This perspective differs significantly from women who organized in the CPC, and CPC (ML), and others who, to varying degrees, identified mistakes made and problems existing in these countries, but continued to uphold Leninism as an important development of Marxist politics in terms of organizing strategy and understanding of imperialism. Burnham and Louie (1985) argued that socialist feminism was "thoroughly anti-Leninist" in the United States (19). But, in Canada, the revolutionary trend within socialist feminism became closely associated with Trotskyist organizations like the League for Socialist Action (LSA) and especially the Revolutionary Marxist Group (RMG). These groups were not anti-Leninist, although some socialist feminists within their ranks came to embrace anti-Leninist organizational principles (i.e. anti-hierarchy and anti-leadership). Significantly, many socialist feminist women advocated for new forms of organization, not unlike radical feminism, due to their experiences with male-led left organizations suppressing their participation in the movement. While these new forms were not necessarily genderexclusive in the manner of radical feminist ones, they tended to focus on smaller, tighter-knit groups on the one hand, and broader coalitions on the other.

The desire to comprehensively synthesize Marxism and feminism is unique to socialist feminist and Marxist feminist thought. While socialists, and particularly 
women socialists, paid attention to women's issues and demands since the $19^{\text {th }}$ century, only the socialist feminists really strove to unite the two ideological perspectives and their politics. Some variation of the slogan "no socialism without feminism/no feminism without socialism" is commonly referenced both in my interviews and in the literature. Debbie Field explained,

No socialist revolution without feminist revolution, no feminism without socialism. That's mostly what we were trying to look at so if we were looking at women's issues, we tried to look at them in terms of the class basis and how it affected working-class and poor women. ${ }^{7}$

This synthesis became the primary subject matter for many socialist feminists entering academia. Many saw bridging socialism and feminism as important due to failures of both the Old and New Left to incorporate issues of violence against women, childcare, and reproductive rights into their programmes. Socialist feminist women came up against leaders who told them that these problems were either not socialist issues or were secondary matters to be worked out later. Socialist feminists saw these issues as primary and argued that if Marxism and feminism could be successfully brought together, it would result in a stronger movement for socialism and women's liberation.

To summarize, socialist feminism can be defined as a political movement and ideology that developed from the late 1960s and into the late 1980s. It grew alongside new social movements in a time of political upheaval and increased social consciousness. It had a direct and oppositional relationship with radical feminism,

\footnotetext{
${ }^{7}$ Field, interview with author, November 8, 2018.
} 
which gradually became more sympathetic with regards to issues of patriarchy and hierarchy. However, socialist feminists' never conceded to radical feminists' understanding of patriarchy as trans-historical or as "the most important structure of domination" (Adamson and Molgat 1988: 5). Socialist feminism contained aspects of both the Old and New Left but often rejected Leninism and distanced itself from the legacies of the Soviet Union and China. In particular, socialist feminists looked for new ways of organizing that they saw as more democratic, non-hierarchical, and prefigurative but even these decentralized methods became hotly contested. Socialist feminism was heavily influenced by Marxism and some socialist feminists, particularly in the academy, worked to create a theoretical synthesis of Marxism and feminism. However, not all socialist feminists were Marxists, and many identified more closely with social-democracy. Regardless of these differences, all socialist feminists shared a common goal of engaging working-class women in socialist struggles and bringing feminism to leftist organizing.

\subsection{Summary of Key Findings}

My key findings are as follows:

1. Socialist feminist activity was most pronounced in the labour movement and women's movement in the 1960s - 1980s. In the labour movement, socialist feminists, along with other socialist women, pushed to mobilize around reproductive rights, childcare, equal pay, and other issues. They helped to create women's caucuses in both the Canadian Labour Congress and Ontario Federation of Labour. In the women's movement, socialist feminists brought a working-class perspective to organizations like the National Action 
Committee on the Status of Women. They were also heavily involved in the reproductive rights movement and participated in the Abortion Caravan and the establishment of illegal abortion clinics. Furthermore, they joined in solidarity with anti-racist and anti-imperialist/anti-war struggles.

2. Socialist feminists shared the goal of achieving women's liberation through socialism, as first expressed in Canada by early socialist women organizers. That being said, socialist feminism is distinct from early organizing efforts in various ways. For example, socialist feminists were the first to try to synthesize Marxism and feminism. Early socialist women, on the other hand, rejected the women's movement as bourgeois. Second, while early socialist women focused their organizing efforts on political parties and the trade union movement, socialist feminists worked in various organizations and formed loose coalitions with women across class differences.

Understanding the distinct location of socialist feminism vis-à-vis early socialist women's organizing shows how Canadian socialist women's aspirations and understandings of liberation changed. Furthermore, it shows what socialist tendencies influenced socialist feminism. Many socialist feminists took inspiration from Leon Trotsky and organized in Trotskyist organizations like the League for Socialist Action (LSA), Revolutionary Marxist Group (RMG), Revolutionary Workers League (RWL), and Fourth International. This helps to explain why socialist feminism is distinct from the socialism espoused by the Communist Party of Canada, Communist Party (Marxist-Leninist), and other Maoist and Marxist-Leninist organizations. They 
differed on questions of organization (whether it was possible to have socialism in one country), the Soviet Union (criticism of the USSR post-1924), and orientation towards the NDP. These differences mirrored some of the splits in the communist movement of the $20^{\text {th }}$ century.

3. Socialist feminism is sometimes presented in British and US literature as necessarily tied to anti-hierarchy, prefigurative, and consensus-based politics. This portrayal does not adequately reflect the Canadian experience. ${ }^{8}$ Canadian socialist feminists were divided on issues of organization. Some were active in "vanguard" organizations, some within consensus-based organizations, and, often, they found themselves active in multiple organizations with differing perspectives on leadership and decision making.

Socialist feminists' experiments with non-hierarchical, prefigurative, and consensus-based politics were meant to address the marginalization that women encountered in various leftist organizations. However, when socialist feminists embraced these new ways of organizing they led to new problems and sometimes exacerbated existing issues. For example, Indigenous and racialized women pointed to their marginalization in these organizations (Nolan 1987; Peters 1987; Barker 1987) and some women complained that the structure and organization of the group exasperated these issues (Black Women's Collective 1986b). Others argued that consensus made it difficult for

${ }^{8}$ Indeed, it may not accurately reflect the experience of U.S. and British socialist feminists, but it is regardless, part of the dominant narrative around socialist feminism. 
political groups to build momentum and come to an agreement on political demands.

\subsection{Methods, Theory, and Methodology}

To better understand the history of socialist feminism, I drew on published literature, archives, and interviews. I carried out a literature review of the work on socialist feminist activism (1960s - 1980s) with a focus on organizational strategies and political orientation. This review touched on the work of Peggy Morton, Margaret Benston, Nancy Adamson, Linda Briskin, Margaret MacPhail, Meg Luxton, Susan Ferguson, Ian McKay, Joan Sangster, and others. I also drew heavily on the Rise Up! Feminist Archive. The Rise Up! Archive presents a unique opportunity for researchers to examine socialist feminist history. This digital archive is composed of "original publications, documents, flyers, posters, and many other materials representing feminist activism from the 1970s to 1990s" (Rise Up Feminist Archive 2018a: n.p). Some of the members of the archive's organizing group were actively involved in socialist feminist struggles and many of their projects are preserved in the archive including some personal accounts of the perceived strengths and weaknesses of socialist feminist struggles. The original intention of the archive was "to digitize three Toronto-based feminist publications: Cayenne, Rebel Girls' Rag and the International Women's Day Committee [Newsletter] (Rise Up Feminist Archive n.d.). These publications were all written from the perspective of socialist feminists who were organizing during 1970s - 1980s. They and other materials in the archive (poster, pamphlets, correspondence) touched on many of the debates between different segments of the women's movement, reviewed ongoing actions throughout the 
country, and were helpful in understanding the issues on which socialist feminists were focused.

I also visited the Canadian Women's Movement Archives which "contains more than 170 archival fonds and collections related to the history of women in Canada, with particular emphasis on the feminist movement since the 1960s...Included in the archives are records for more than 350 grassroots organizations and diverse women's groups" (University of Ottawa Library n.d.). Here I found pieces that were missing from the Rise Up! collection, including some early work which is said to have inspired socialist feminist theory and practice. The Canadian Women's Movement Archives also contains material on the Abortion Caravan, National Action Committee, Communist Party of Canada, Communist Party of Canada (Marxist-Leninist), League of Socialist Action, International Women's Day and other campaigns and organizations which socialist feminists played an integral role.

I drew from the Communist Party of Canada's private collection for past issues of Young Worker, New Horizons, and the Young Communist Leagues' compilation of articles on women's struggles. This helped me to understand how women in the Communist Party were organizing in the 1970s - 1980s and how this differed from socialist feminists. In addition, to understand early socialist women's organizing, I consulted the Ontario Archives which contains material about the Communist Party's Women's Department, Women's Labour Leagues, Delegation to the USSR, and information about women's strikes and unions. This helped me to understand the 
continuities and discontinuities between early socialist women's organizing and socialist feminist organizing beginning in the 1960s.

Other documents that I drew on include my personal collection, which is made up, in part, by donations from Heather Jon Maroney. This collection is composed of documents from International Women's Day, Organized Working Women, Toronto Women's Liberation, Worker's Action, Vancouver Women's Caucus, and others. Appendix 1 contains a more detailed account of the sources I drew on.

It became clear early on in my research that socialist feminists and left activists in the 1960s - 1970s often compared their organizing efforts to those of the Old Left. Thus, I began to explore the early organizing work of socialist women in Canada around the woman question. I drew on the work of scholars and historians like Linda Kealey, Janice Newton, Carol Lee Bacchi, Joan Sangster, Stephen Endicott, Patricia Connelly, Maureen Baker, Mary-Anne Robeson and others to understand the relationship between the early women's movement and socialism (1900s - 1950s).

I also conducted semi-structured interviews with women activists who organized in the 1960s - 1980s. I used these interviews to help orient and fill gaps in my research and provide personal accounts from activists. The combination of interviews and archival records were key to the success of this research. I found that interview participants often remembered snippets of a debate, campaign, or organizational detail. From that, I could discern what to search for in the archives and sometimes find their original contributions.

In total, I conducted 11 interviews that averaged 1.5 hours each. I choose semistructured interviews so that I had room to explore themes and responses emerging 
from each interview. I asked participants about their experiences in various socialist and feminist organizations, their thoughts on socialist feminists' contributions, their experiences with coalitions, prefigurative and consensus-based politics, what their relationship was with the broader socialist left, how men reacted to their organizing efforts, and what they saw as the biggest obstacle to women's emancipation. I also tailored questions to individuals based on their political background. For example, if a participant was involved in a particular organization (e.g. Revolutionary Marxist Group, Coalition for Abortion Clinics) I asked them about the particular goals, demands, organizational structure, and alliances of that organization. I also asked them about debates in those organizations and any tensions between organizations in which they were involved and other left organizations.

Participants were chosen based on snowball sampling. A strength of snowball sampling was that it helped me to understand the connections between activists and their various organizations. A limitation of snowball sampling was that the study became Toronto-centric when the original intention was to have a broader perspective of the movement in the whole of Canada. That said, a lot of socialist feminist organizing was concentrated in the Toronto area.

My interview participants were Meg Luxton, Judy Rebick, Carolyn Egan, Liz Rowley, Marilyn Porter, Linda Kealey, Marjorie Cohen, Debbie Field, Kathryn Petersen, Amy Gottlieb, and Varda Burstyn. All of the interview participants selfidentified as socialist feminists or Marxist feminists in the time period I was examining, except Liz Rowley who identified as a communist. Some of the organizations in which participants were involved included the Toronto International 
Women's Day Committee, League of Socialist Action, Revolutionary Marxist Group, Revolutionary Workers' Party, New Democratic Party, the Fourth International, Toronto Socialist Feminist Action, Organized Working Women, Ontario Coalition for Abortion Clinics, Canadian Labour Congress, Ontario Federation of Labour, Communist Party of Canada, Canadian Union for Public Employees, Abortion Caravan, and the National Action Committee on the Status of Women. Appendix 1 contains a breakdown of who was involved in what organizations. Most everyone I interviewed began organizing in the late 1960s or mid-1970s. But, it was the mid-1970s when socialist feminists politics received more clout and distinct socialist feminist organizations were formed.

A limitation of this study is that the interview participants are all white activists. This means that the perspectives of Indigenous and racialized women are not adequately reflected. Further study is warranted to cover these views and how socialist feminists' organizations were viewed from outside. Some of this tension is explored in Chapter 4 in the debates around IWD and the Toronto Feminist Bookstore. What becomes clear in Chapter 4, is that while socialist feminists saw some of their work as anti-racist, it might be more accurate to say they were trying to grapple with new perspectives. A second limitation of this study is that, while this dissertation offers some contextual material which references the broader Canadian context, language was a barrier to including the Quebec experience. It's also important to note that the feminist movement in Quebec was distinct from the feminist movement in the rest of Canada. Sangster (2001) explains, "the dynamics of Quebec as a distinct nation, inside and subordinated to the rest of Canada and 
particularly the Canadian state" meant that Quebec developed its own francophone feminism. Though there was cooperation and collaboration between Quebec feminists and feminists outside of Quebec, this study does not incorporate that analysis.

\section{Theory and Methodology}

All historians and historical sources are shaped by political, economic, and social circumstances. In recounting history, one must selectively choose which facts to present and how. As E. H. Carr (1961) wrote, "the belief in a hard core of historical facts existing objectively and independently of the interpretation of the historian is a preposterous fallacy, but one which it is very hard to eradicate" (12). Take for example, the conversations that are taking place with the passing of the fiftieth anniversary of the tumultuous year of 1968. This anniversary has renewed conversations about how the radicalism of the 1960s and 1970s should be understood and remembered. Some remember this period fondly as a time of increased radicalism and attempts to build new political projects and organizations (Edgar 2018, Elbaum 2018). Others remember it as the beginning of the fall of organized labour and trade unions despite incredible fightback (Windham 2017). Still others see it as a reflection of the failure of New Left or Old Left politics (Kettle 2018). The interpretations are varied and sometimes overlap but conflicting ideas about the legacies of this era can be considered a product of past and current political divisions. In other words, there is a political basis to who, what, and how things are remembered. Even among socialist feminists, the legacy of socialism, and the 
women's movement during its heyday, are interpreted in various and contradictory ways.

Throughout this dissertation, I do my best to understand what politics and historical events are contributing to what analysis and how these analyses played a part in shaping political action. By considering the history of the Left, we can learn about "how people came together to win struggles" as well as what forces inside and outside their organizations led to defeat (Ferguson 2014: 166). In doing this, it is also possible to examine what "ideas helped to clarify and strengthen political action, and what ideas divided and disempowered us" (Ferguson 2014: 166).

For my purposes, an historical materialist methodology means that the historical analyses required by this project must be grounded in the political and economic conditions in Canada and its development, including class struggle. Any time that workers defend against cutbacks or fight for better standards, that activists and community members organize to confront particular problems in their communities, or revolutionaries attempt to overthrow the existing order, the strategies they use are put to the test, as is their appraisal of the objective conditions governing the potential of their actions. I do not believe that we can look to the past for a prescriptive formula for overcoming today's problems. The rightness or wrongness of a political approach must be understood in relation to the context in which it was tried. I seek to understand how socialist feminist organizing was influenced by the historical development of socialist struggle in Canada.

Historical materialism also offers us a starting point for examining the relationship between women's oppression and social reproduction, in so far as "the 
production and reproduction of the immediate essentials of life" are "the determining factor in history" (Engels 2007 [1884]: 71). That is, we start not with ideas about women but with the actual lives of women. Marx and Engels had an undeveloped hypothesis about women's oppression. Drawing on the anthropological evidence of their time, they argued that women's oppression coincided with the rise of private property and surplus production. In The Origin of the Family, Private Property, and the State, Engels argues that "primitive communist" societies, citing the Iroquois (Haudenosaunee), treated women as equals (2010 [1884]). While the anthropological evidence on which they based their conclusions is riddled with errors, their observation on the origins of women's oppression is accepted by many of today's historians and experts. ${ }^{9}$

\subsection{Flashpoint Interventions and Key Debates}

This review focuses on key debates and interventions that were foundational for socialist feminists in 1960s - 1980s. These were flashpoint interventions which help set the stage for the next set of debates around organization and strategy. I begin with a discussion of three texts, "Sisters, Brothers, Lovers...Listen," "The Political Economy of Women's Liberations," and "Feminist Organizing for Change," that have been credited as being the first socialist feminist writings in Canada. These accounts highlight women's struggle in the Old and New Left and discuss political organization.

\footnotetext{
${ }^{9}$ Brian Baggins (2010) created a footnoted guide in Origin of the Family to help readers "critically assess" Engels' work "in face of recent scientific evidence." Baggins (2010) and others argue that Engels' main conclusions "remain true to this day" and demonstrate "how effective Engels' dialectical method [is]" (n.p). Similar conclusions are reached by Chris Harman (1984), Chrysochou (2013), Sayers, Evans and Redcliff (2010), and Smith (1997).
} 
In addition, I examine some more contemporary works that help situate socialist feminism within the broader socialist movement and that explore the strategies of the movement.

\section{Sisters, Brothers, Lovers...Listen}

In 1967, Judi Bernstein, Peggy Morton, Linda Seese, and Myrna Wood wrote what is credited as one of the first Canadian socialist feminist papers, titled "Sisters, Brothers, Lovers, Listen..." The paper was originally written for a membership conference for the Student Union for Peace Action (SUPA). The authors' goal was to bring to light the subordinate position of women within the organization so that solutions could be discussed and enacted (Bernstein et. al. 1967). The paper became a seminal text after it was picked up by the New England Free Press. Its publication allowed it to be circulated more widely and women organizers outside of SUPA related to the experiences described by Bernstein, Morton, Seese, and Wood. The publication situates the activity of Canadian socialist feminists in a New Left movement.

SUPA was a New Left group formed in Regina, Saskatchewan in 1964 to oppose war and Canada's international role. The group espoused participatory democracy as a goal, which, internally, was supposed to encourage all members to take active roles in the organization and its decision-making process. Bernstein et. al. argued that, instead, women's position within SUPA resembled their subordinate position within Canadian society. In SUPA, women were excluded from leadership roles and decisionmaking, and were relegated to roles supporting the male leadership. Morton (2005) recalls, 
Four of us wrote a paper called "Sisters, Brothers, Lovers, Listen..." That paper sparked a lot of discussion. If you read it today, it's a pretty funny paper. But it sparked a lot of discussion and debate. We were people who just assumed we were in this movement that was about freedom and liberation and justice and rights, and that we were going to be treated with freedom and justice and rights. Then we found out that we weren't, that we were expected to do all the grunt work in the organization. All the leaders with big egos would do their thing, and we would make sure that everything got done and they would take all the glory. I don't think we were looking for glory, but we just wanted some recognition (n.p).

Bernstein et. al. drew on Juliette Mitchell's (1966) influential book Women: The Longest Revolution as a way to understand women's oppression. Mitchell, a socialist feminist based in England, saw women's oppression taking place in four distinct realms: production, reproduction, socialization, and sexuality. She argued that the family, and women's roles within it, were not a fact of nature but a "cultural creation" (11). For Mitchell, there was "nothing inevitable about the form or role of the family" or "about the character or role of women" (1966: 11). Yet, women were expected to fulfill motherly duties by tending to their children and husbands without complaint.

While Mitchell saw part of women's oppression as rooted in socialization, she argued that it wasn't enough to challenge sexist ideas about women. Women's liberation would require the overthrow of existing relations of production. She argued, "in advanced industrial society," women's work was only "marginal to the total economy," and that "until there [was] a revolution in production, the labour situation [would] prescribe women's situation within the world of men" (11). In other words, until women were fully incorporated into the productive sphere, there could 
be no equality between genders. This idea, she argued, was "recognized by all the great socialist thinkers in the $19^{\text {th }}$ century" and was "part of the classical heritage of the revolutionary movement," but that the later socialists had abandoned it (12).

Bernstein et. al. (1967) applied Mitchell's analysis to their situation in Canada and within political organizations on the New Left. They argued, "SUPA people have the same hang-ups, frustrations, and neuroses [towards women] as the rest of society" (5-6). Women were responsible for work in the home, workplace, and even within leftist political organizations. Women organized so that "their partners [could] run around being political, creative, writing, thinking, and oozing charisma" (Bernstein et. al 1967: 6). They wrote damningly,

One role for women is that of servicing the organization's men. These women maintain the stable, homey atmosphere which the radical men need to survive. They raise the future radicals of Canada. They earn the money in the mundane jobs...so the radical men can be at home and be political, creative and so forth...The workers of the movement...they are the typist, fundraisers, and community organizers...We are allowed to speak but our thoughts are not given serious attention until expressed by a male (Bernstein et. al. 1967: 6).

Furthermore, women, they argued, were ready for revolution. Women's experience of sexism and discrimination in organizations was leading them to reject "many of the traditional leaders as irrelevant" (7). The authors concluded that "until the male chauvinists of the movement (North America and worldwide) understand the 
concept of liberation in relation to us, the most exploited members of any society, the women, they will be voicing political lies" (Bernstein et. al. 1967: 7).10

It is telling that one of the first socialist feminist articles was written in response to the discrimination women felt in the political organization to which they belonged. This demonstrates that socialist feminist theorizing began in response to women's experiences in New Left struggles where consensus and participatory democracy were well-established. I will show later how women's exclusion from leadership roles and their relegation to "workers" in the movement, led many socialist feminists to be fierce supporters of non-hierarchical or consensus-based organizational structures. Nevertheless, it was within an organization that claimed to be a participatory democracy that socialist feminists first wrote about their frustration with male hierarchy. Furthermore, the article demonstrates that divisions of labour and power relations were central to socialist feminist analysis from the very beginning.

\section{The Political Economy of Women's Liberation}

Two years after "Sisters, Brothers, Lovers...Listen" critiqued women's treatment in SUPA, Margaret Benston's (1969) Monthly Review article, “The Political Economy of Women's Liberation" was published. This article has been credited by Susan Ferguson (2008), Meg Luxton and Heather Jon Maroney (1987) as the catalyst of socialist feminist theory in Canada. In the article, Benston addresses women's work

\footnotetext{
10 Note here that Bernstein et. al. did not put forth an analysis of how women's exploitation and oppression differed based on race, nationality, disability, and sexuality. They, like many second wave feminists, saw women as experiencing exploitation and oppression in similar ways. That said, their opinions of this changed as their political analysis developed through struggle.
} 
with a concentration on household labour and how it is gendered. Benston (1969) begins her article by calling attention to the failure of mainstream political analyses on the Left to consider women in class analyses:

The 'woman question' is generally ignored in analyses of the class structure of society. This is so because, on the one hand, classes are not generally defined by their relation to the means of production, and on the other hand, women are not supposed to have any unique relation to the means of production.

...The status of women is clearly inferior to that of men, but analysis of this condition usually falls into discussing socialization, psychology, interpersonal relations, or the role of marriage as a social institution. Are these, however, the primary factors? In arguing that the roots of the secondary status of women are in fact economic, it can be shown that women as a group do indeed have a definite relation to the means of production and that this is different from that of men (1).

For Benston, it was important to consider women's oppression as rooted in capitalist political economy. Women's unpaid labour, she argued, is necessary to the function of capitalism, in two main ways. First, Benston noted, women play an important role in reproducing the working-class by giving birth to and raising children, and generally maintaining the household without a wage. A woman's maintenance of the household also ensures that her husband is fed and cared for, so that he can return to work each day. Secondly, Benston observed, women act as a reserve army of labour for capitalists who, when in need, draw on women's labour to fill positions typically reserved for men. Benston looked to the history of industrialization and the two World Wars to demonstrate this phenomenon. ${ }^{11}$ Thus, Benston's conclusion is that

\footnotetext{
${ }^{11}$ I outline this history in Chapter 2.
} 
women "are not only discriminated against" but "exploited" (Benston 1969: 11). For Benston (1969), women's liberation must then entail a restructuring of public and private life. She argued that "work now done in the home as private production" must be transformed "into work to be done in the public economy" (8). She continued,

To be more specific, this means that child-rearing should no longer be the responsibility solely of the parents. Society must begin to take the responsibility for children; the economic dependence of women and children on the husband-father must be ended. The other work that goes in the home must also be changed - communal eating places and laundries for example. When such work is moved into the public sector, then the material basis for discrimination against women will be gone (8-9).

This is an important contribution as it roots women's liberation in a society that provides basic needs and services to the people. However, Benston does not state how she envisions this transition to a socialist society and what role women must play in this transition. Other scholars and activists (Peggy Morton and Selma James) have suggested that her theory of women's oppression lent itself to a strategy of disengagement from the family/private sphere. This strategy became associated with the radical feminist movement but was not widely endorsed by socialists and socialist feminists. In the following section, I will discuss how Peggy Morton built on Benston's work and suggested a different strategy for women's liberation.

\section{A Woman's Work is Never Done}

One year after Benston's article, Peggy Morton wrote “A Woman’s Work is Never Done, or, the Production, Maintenance, and Reproduction of Labour Power." Morton's article is cited by Gorham (1988), Vogel (1989), Andrew, Armstrong, 
Armstrong, Wallace and Vosko (2003) as an important development in socialist feminist analysis. Morton's analysis was similar to Benston's, in that she argued the family was the "unit whose function is the maintenance of and reproduction of labour power" (7). Morton also understood the family as "determined by the needs of the economic system, at any given time, for a certain kind of labour power." Morton credits Benston's article as being "one of the first arguments that we must analyze the role of women in the family from the point of view of production rather than consumption (4). She argues, "Benston correctly situates the oppression of women as stemming from their role in the family and correctly argues that real contradictions exist for women as women, and not only on the basis of their class position" (Morton 1972: 4-5).

The key difference between the two articles is, as Selma James (1975) argued, in their calls for action. Benston's article does not clearly articulate a strategy for overcoming women's oppression. Instead, if one follows her logic, the strategic conclusion is that women must either leave the responsibility of their homes so that capitalists will be forced to industrialize housework or that they lobby and demonstrate until such a reform is met. James (1975) argued, "this wins us the right to be exploited equally with men" and never addresses women's oppression in the workplace (52). This is where Morton and Benston's analysis diverge. Morton argued that the chief problem with Benston's article is,

that it does not provide any basis on which strategy for a women's movement can be based...to define women through their work as unpaid household labourers does not help us to understand how to organize women. The logical conclusion would be that women should be organized around their 
relationship to production, i.e. organized around their work in the home. Yet the isolation of housewives, which is an important aspect of their oppression, is also a great barrier to their organization (4-5). ${ }^{12}$

Indeed, Morton took up this issue in relation to the women's movement more broadly, which she argued often forgets that the goal of organizing women is to build a mass movement which is capable of overthrowing the existing power relations. Too often, she argued, the women's movement is focused on raising women's consciousness, as if this was a way, in itself, of changing the prevailing conditions. Morton (1972) explained,

The greatest obstacle is not 'false consciousness' but not knowing how to fight the family system...revolutionary movements are born out of the consciousness that people already have of their oppression and the transformation of individual understanding through collective action which produces a higher level of consciousness. The women's movement will grow out of this consciousness. It is our own chauvinism towards other women that keeps us from understanding how much women already understand about their own oppression (2).

Therefore, the problem at hand was not a matter of writing analysis to prove the existence of this oppression, or bringing women together in consciousness-raising groups, but of organizing. Morton saw activists as too focused on justifying "the importance of women's liberation" and on a "collective understanding of our

\footnotetext{
12 Early socialist women had attempted this strategy in the Communist Party and Women's Labour Leagues. They tried for many years to organize housewives with little success because of their isolation in the home. This is exactly what is surmising here but with no references to a prior organizing period that can point to these difficulties.
} 
oppression" instead of seeing "analysis as a tool for the development of strategy" (emphasis original 1972: 2).

For Morton, women's revolutionary potential lied "in the fact that most working women are both oppressed as women and exploited as workers." Any political "strategy must reflect this duality," she stated (19). Morton articulated that women must "organize around demands which provide the pre-condition for the autonomy for women - economic independence. This struggle will in fact heighten the contradictions within the family systems" (Morton 1972: 19). This strategy is notably different from that implied by Benston, since it does not ask women to abandon or "destroy the family." In contrast to Benston, and some subsequent feminist authors, Morton argued that the family is one of the last places the workingclass holds onto for their "basic emotional needs for love, support and companionship," because "there are no [current] alternatives" (19).

Morton's article was primarily concerned with developing a strategy for liberation. I've shown that two of the founding texts of Canadian socialist feminism are an explicit discussion of political organization and strategies for mobilization, this becomes less common throughout the 1980s and into the present day. While some work has been done to chronicle socialist feminism as a political movement, political mobilization and strategy is an under-theorized area in the literature. There are some exceptions.

\section{Feminist Organizing for Change}

One exception is Nancy Adamson, Linda Briskin, and Margaret MacPhail's (1988) Feminist Organizing for Change which discusses political strategy in some 
depth. The authors saw socialist feminism as a viable theory for socialists and women's liberation activists but argued that "theoretical analyses" did "not provide clear answers to the specific questions of practice: what issues to take up, what demands to make, what methods of organization to use" (Adamson et. al. 1988: 169). In other words, while the authors embraced the principles and theory of socialist feminism, they also recognized that this did "not provide a step-by-step blueprint to practical struggle or to the future" (Adamson et. al. 1988: 126). They argued, "in the world of practical politics...feminists within a particular current may disagree as often as they agree, both on the correct interpretation of theory and on its practical application (Adamson et. al 1988: 170). Nevertheless, Adamson et. al. made some comments about the nature of socialist feminist practice, they state, "socialist feminist strategy emphasizes political confrontation in the public domain - for example, against the government or in the workforce" (Adamson et. al. 1988: 174). Ultimately, they saw socialist feminists as playing an important role in the women's movement by winning over the masses to their political analysis:

We must set our sights on building a women's movement of hundreds, and then thousands, of women. A mass women's movement composed of alliances of women's groups would be heterogeneous politically, and it is essential that such a movement avoid political sectarianism. It must be the democratic right to contribute and to form tendencies to develop strategy. Policy must be set after formal, democratic debate and vote, with majority decisions abided by. In such a movement we would attempt to play an educational and leadership role in winning women to a feminist-socialist perspective.

Their conception of political practice is different than consensus and anti-hierarchical models that some socialist feminists advocated for. Adamson et. al. envisioned the 
movement as being cross-class and encompassing various political ideologies. They believed that the strength of socialist feminist analysis would be enough to convince the majority of women to see things from their perspective.

Their analysis also focused in on a significant debate of the time, the question of engagement and/or disengagement (mainstreaming) with the state and what a socialist feminist approach would entail. A strategy of disengagement meant operating outside of mainstream structures like government while a strategy of engagement meant operating within mainstream structures. Women's groups had a complicated relationship with the state in the 1970s and 1980s. Sometimes the state provided them with considerable support through funding while simultaneously acting as a barrier to many of their demands. Furthermore, when women's organizations, like the National Action Committee on the Status of Women, grew more critical of the state and embraced a politic that directly opposed an elected federal government, they faced defunding.

Adamson et. al. argued that a socialist feminist approach should advocate for a balanced engagement with and disengagement from the state according to what would serve political change at any given moment. They argued,

In summary, we would argue that there are two basic aspects to feminist practice for change. On the one hand, it is clear that social change comes out of a critique of the existing system and out of a vision not only of a new social order, but also on how to end the oppression of women. Without this critique and vision there is no recognition that change is needed, and no momentum to make it take place. Yet it is equally clear that change requires that these ideas be accepted and acted on by the majority of people. To achieve this, feminists also need to develop a practice that engages with the actual concerns of people, 
and thus with existing institutions and ideologies (Adamson et. al. 1988: 179). ${ }^{13}$

The authors tease out some of the risks associated with each strategy. Simply, disengagement ran the risk of marginalization from the public and engagement ran the risk of institutionalization/co-optation. Socialist feminism, with its critique of the state and existing economic relations, ran the risk of marginalization. Thus, it was crucial that socialist feminists find a balance between disengagement and engagement.

The question of engagement with the state was wrapped up in debates about whether to engage or disengage with the NDP. The authors supported the NDP as a place to struggle. They argued that "the existence of the NDP and its commitment to a progressive platform on women's issues, at least in principle, has had an impact on the development of the socialist feminist strategic organization to the government and state apparatus..." (Adamson et. al. 1988: 123). The NDP was presented as a way that socialist feminists could become involved in state politics and push for progressive policies on childcare, pensions, and labour legislation. That said, Adamson et. al. also recognized that the NDP could work against their interests. For example, the NDP "periodically had obstacles put in the path of [feminists] attempts to get issues of abortion onto the floor during policy conventions" (Adamson et. al.

\footnotetext{
13 This same thing was argued by Briskin and Dehli at a conference a year earlier. They argued that socialist feminists should avoid "'Smash the state! Build alternatives!' purism" and instead embrace "more concrete socialist feminist theory of the state" that emphasized the "Canadian state as a site for struggle for women and the success of Canadian feminists in having forced different levels of the state to take up issues such as pay equity, pensions, abortion access, child abuse, and women's shelters" (as cited by Weir 1987: 94).
} 
1988: 183). In addition, in Manitoba the NDP decided to charge organizers of a freestanding abortion clinic there.

\section{Feminism as a Class Act}

Meg Luxton's (2001) “Feminism as a Class Act” provides an important account of the women's movement in Canada. In it she touches on the roots of the women's liberation movement from which socialist feminism emerged. Luxton shows a strong working-class and socialist feminist presence in the women's movement since the 1960s and 1970s, countering the stereotype that the women's movement at this time was led by bourgeois and liberal women. Instead, she argues, the labour movement provided grounds for women's activism. As women entered the workforce in greater numbers, they "fought in the workplace and in the unions for better conditions" fuelling "the developing women's movement" (70).

Socialist feminists, while often involved in the trade union movement, were distinct from labour feminists. ${ }^{14}$ What made socialist feminists unique was their critique of capitalism. According to Luxton (2001), socialist feminism was influenced by the emergence of New Left organizations "such as the Student Union for Peace Action, the Company of Young Canadians, later in the Waffle...and various Marxist and Leninist organizations associated with international Trotskyist, Maoist, and anarchist movements" (83). While these left-wing organizations were "always numerically small" they "offered a sophisticated political analysis and energetic political

\footnotetext{
${ }^{14}$ Throughout this dissertation I talk about labour feminists, socialist feminists, and socialist/communist women. Labour feminists are those who struggled within the labour movement for pay equity, maternity leave, and other job protections for women. There is some overlap between labour feminists and socialist feminists and socialist/communist women. However, most labour feminists did not identify as socialist. Socialist/communist women are those who identified as socialists but did not come from the socialist feminist tradition that I've defined in section 1.2.
} 
organizers in most cities...They took those lessons into the unions and the autonomous women's movement" (Luxton 2001: 83-84). Thus, much of the "women's liberation movement" also "developed in the context of the New Left" (Luxton 2001: 83).

Organizationally the women's movement in Canada “tended to appear as tiny local groups that came together for a period of time after which the members dispersed to other groups" (Luxton 2001: 84). Activists were "less concerned about developing enduring organizations and institutional forms" and instead "relied on informal networks between individuals and small groups" (85). According to Luxton, "they also set up collectives to provide services to women and strengthen the public face of the women's liberation movement" (85). She touches on the role that some women activists saw prefigurative politics playing; "often these were also intended to prefigure new liberatory ways of organizing society. Communal and co-operative housing efforts, worker co-ops such as bookstores and community centres attempted to develop alternative structures to oppressive sexual, marital and familial relations, and to exploitative capitalist businesses. Parent and worker run co-operative day care centres experimented in ways of raising children more collectively" (85).

Luxton (2001) characterizes the difference between the liberal and left-wing feminist strategies. She argues, both groups agreed that "the agenda of the women's movement demands an expansion of the social welfare system and greater government receptivity to women's issues" (80). The difference between them was that this was liberal feminists' overall strategy, their end goal, while left-wing 
feminists saw the expansion of the social welfare system only as "a tactic" (80). Luxton (2001) argues that "most socialist feminist initiatives assumed the state was both capitalist and patriarchal and therefore hostile to women's concerns. Strategically, socialist feminists aimed to enable and empower women to act on their own behalf politically, rather than relying on leaders" (86). The socialist feminist movement was influenced by politics of anti-hierarchy and prefiguration (Luxton 2001). For left-wing feminists real change would "come from the mass mobilization of women challenging capital" (Luxton 2001: 80). Socialist feminists sought "to build coalitions that would generate mass, militant actions such as demonstrations, rallies, and public meetings" (Luxton 2001: 86). They "tried to ally not only with other feminists and with anti-racist and lesbian and gay activists, but also with other organizations such as anti-imperialist solidarity groups and aboriginal groups" (86). This aligns with her understanding of the feminist movement more broadly in Canada which "tended towards a politics of solidarity based on coalitions that recognize different constituencies" (Luxton 2001: 66).

\section{Reds, Rebels, Radicals}

In Ian McKay's (2005) view, socialist feminism was a new and distinct left formation that challenged some of the previous prejudices within the socialist movement. He characterizes socialist feminists as those who "described themselves as revolutionaries" and "who identified strongly with the revolutionary-utopian side of Marxism" (196). Additionally, he argues, socialist feminists, though influenced by Marxism, were critical of the history of Marxism; "many socialist feminists experienced a kind of visceral repugnancy - not only against the transparent 
exaltation of male power and privilege in Marxist texts and symbols, but also against the textual authority and epistemological absolutism of the (actually existing) Leninist versions of 'scientific method'" (McKay 2005: 196). McKay's characterization differs from some that saw socialist feminism as encompassing both Marxists and anti-Marxist social democrats.

McKay (2005) argues that socialist feminism rose "to a position of ideological centrality within the New Democratic Party" in the 1970s - 1980s (198). This came after their participation in the Waffle movement in the early 1970s (McKay 2005). But McKay does not expand on the debates and conversations that socialist feminists were having with party leadership (who were not socialist feminists) and rank-andfile members. I'll touch on this complicated relationship in later chapters. Regardless, McKay maintains that socialist feminists developed a skepticism of state power because they did not see the state as addressing their issues and often stifling their organizations:

over time socialist feminists would develop a more...sceptical and pragmatic...stance towards 'the state' than was to be found in either the CCF or CPC. Not only would the Canadian state engage in the strategies of passive revolution, conceding the minimum of the feminist program in order to contain this moment within the liberal-capitalist institutional framework; but it would also address only a fraction of the issues that feminists saw as being most important (195).

Socialist feminists were attracted to the New Left which called into question "earlier approaches to revolutionary activism" (McKay 2005: 194). McKay characterizes the New Left as emphasizing "authenticity, spontaneity, and radical democracy" (194). 
Yet, while embracing many of the New Left's consensus and anti-hierarchical forms, socialist feminists also condemned the "sexism that, unconsciously or otherwise, persisted in supposedly anti-hierarchical radicalism" (195).

McKay emphasizes the way in which socialist, radical, and liberal feminisms influenced one another. He warns that "these frameworks can be interpreted in an ahistorical way" that oversimplifies their divisions and does not recognize the complex relationship between them. He worries about historical accounts that lock feminists into "fixed-and-firm-identities" (202). While there were differences, the women's movement encompassed various perspectives that were in conversation. He argues, "all counter-liberal feminisms in modern Canada have been socialist in the basic sense of bringing the injustices of capitalism to light and projecting a more egalitarian alternative over and against them" (202). Socialist feminists "struggle within and against feminists who identified themselves with incremental reforms within the liberal order, who focused on questions of personal fulfillment, and who felt no sense of being part of a more general radical movement" (197).

\section{Transforming Labour and Radical Ruptures}

Joan Sangster has written historical studies of pre and post-war socialist and trade union organizations, and their relation to the women's liberation movement in the 1960s. While some argue that socialist feminism was a continuation of early communist, socialist and trade union activities, Sangster concludes that the 1960's women's liberation movement marked a "break with existing left-labor politics" (2010a: 10) and from "the communist 'Old Left' agenda" (2010b: 4). That said, she recognizes that "personal and generational links" helped to bridge the Old Left and 
New Left; however, "these links were not without political tension" (Sangster 2010b: 4). She argues that the women's liberation movement (which included socialist feminists) was its own unique movement emerging from the New Left and critiques of the New Left. These included the criticisms of women activists within SUPA who had "turned a critical eye on the New Left's treatment of women and its failure to live up to ideas of 'human liberation'” (2010b: 8).

Post-war labour feminism, she writes, was "distinct from the emerging current of socialist feminism in the long sixties: the former, generally reformist in nature, looked to the existing labor movement as a vehicle for change, while socialist feminism offered a more thorough-going critique of all capitalist relations, calling for both a 'transformation in the relations of domination between men and women and redistribution of power between classes and races"' (Sangster 2010b: 4-5). Socialist feminism was more closely "tied to Marxist and socialist politics" than the existing labour movement. Nevertheless, socialist feminists saw the labour movement as a place to struggle for their demands and brought a "reinvigorated left-wing presence within the mainstream trade union movement" (Sangster 2010b: 2). Socialist feminists were "more attuned to calls for democratic, participatory politics and direct action, making them wary of the labour bureaucracy and more likely to challenge the male-dominated movement's cautious commitment to industrial legalism from the top down" (Sangster 2010b: 8). Socialist feminists saw their role in the trade union movement as "putting working-class women's economic needs at the center" by "addressing the internal marginalization of lower-paid women" within unions and 
through support of issues "such as abortion, childcare, gay and lesbian rights, and racism" (Sangster 2010b: 8).

Canadian socialist feminists were involved in various new socialist and Marxist-Leninist formations in 1960s. These groups included the Trotskyist Revolutionary Marxist Group, Revolutionary Workers League, and Maoist En Lutte (Sangster 2010b). While differences between the groups were "in their view...quite significant...their combined presence did mark a break with existing left-labour politics, which had been characterized in the post-war period by a tired impasse between the communist party and the CCF/NDP" (Sangster 2010b: 10). Sangster characterizes the New Left and socialist feminist movement as a "revitalization of Marxist debates, disillusionment with liberal social democracy, left-wing nationalism, and Marxist-Leninist party formations" (Sangster 2010b: 7). These New Left formations "developed new analyses of women's oppression" especially around issues of "abortion, sexuality, social reproduction" (Sangster 2010b: 10). These new formations were never able to secure a strong working-class base like the Communist Party but "their organizing had an impact larger than their small numbers, and the experience that new communist women secured (including their later critique of vanguard parties) shared their involvement in union and feminist politics long after [their parties] folded - in some cases, influenced in part by feminist critiques" (Sangster 2010b: 11). Sangster notes that it was generally only the Trotskyists who "promoted the importance of an autonomous women's movement" (Sangster 2010b: $10)$. 


\section{Gap in the Existing Literature}

One of the reasons that I was compelled to examine socialist feminism more closely was the lack of literature on the political work of these activists. While there continues to be a socialist feminist presence in contemporary academic literature, its focus is often on developing theories and concepts useful for understanding women's oppression, and merging feminist, Marxist, and anti-racist perspectives (Ferguson 2008; Bannerji 1995; McNally and Ferguson 2015; Bezanson and Luxton 2006). Other socialist feminists' studies focus on policy-engaged research. They offer policy recommendations on issues like health care, long-term care, education, labour, pay equity, social assistance, and pensions..$^{15}$ All of this is important work and sometimes touches on prior organizational efforts, but there is little work done which critically revisits the organizational vehicle best suited for realizing socialist feminisms' goals.

In particular, I was interested in the differences between early socialist organizers and socialist feminists. As this review of the literature demonstrates, there is already some conversation about this divide. What is missing is a more nuanced conversation about socialist tendencies, how they developed, and what tendencies socialist feminists gravitated towards. As it stands, socialist feminism is portrayed as emerging from Leninist, Maoist, and Trotskyist tendencies. By tracing early socialist women's struggles, this dissertation shows how Trotskyism took a leading role.

Furthermore, while the literature touches on New Left organizational practices that came to influence socialist feminists, it does not reflect on the debates

\footnotetext{
${ }^{15}$ Some examples of this policy-engaged research include: Cohen and Pulkingham (2009); Bashevkin (2002); Brodie (1996); Armstrong and Pederson (2015).
} 
between socialist feminists about the efficacy of these approaches. As Ferguson (2010b) notes, there were intergenerational links between the Old Left and New Left but they were mired in debate. American and British literature presents socialist feminism as married to New Left anti-hierarchical and prefigurative organizational practices. Sheila Rowbotham, Johanna Brenner, Nancy Fraser, Nancy Holmstrom, Lynne Segal and Hilary Wainwright have all explored what socialist feminism can teach us about activism and organizing, but their reflections do not include or adequately represent the Canadian experience. Their work has focused heavily on the perceived benefits of non-hierarchical movements, prefigurative politics, and new social movement theories that often eschew affiliation with Leninism and sometimes political parties altogether. ${ }^{16}$ While some socialist feminists in Canada have been influenced by and have advocated for similar politics, historically, there is much debate.

My research fills gaps in the literature on Canadian socialist women's organizing and begins a conversation about how the legacy of socialist feminism can be understood within the context of the broader struggle in Canada. Socialist women's struggle in Canada has been diverse politically, ideologically, and strategically. Even women in the same political organizations could have differing opinions about their strategic direction. It is clear from my research that no one strategy can be considered socialist feminist. While socialist feminists were more willing to experiment with New Left forms of organization, like prefiguration, non-hierarchical organizational

\footnotetext{
16 Brenner (2014a; 2014b), Rowbotham, Segal, and Wainwright (2013), Holmstrom (2002), Arruzza, Bhattacharya, and Fraser (2019).
} 
structures, and consensus-based decision-making, debates and splits emerged around these strategies and their political implications. The inability to resolve these differences, which became more acute in the 1980s, contributed to organizations dissolving or emerging significantly weakened. 


\section{Chapter 2: Early Communist and Socialist Women's Resistance}

As I noted in Chapter 1, many socialist feminists claim that socialist feminism originated in the struggles of early socialist women. They uphold Kollontai, Zetkin, and Luxemburg as socialist feminists who paved the way for later socialist feminist activities. But what of the struggles of early socialist women in Canada? What commonalities and differences do they have with Canadian socialist feminists? Is it possible to trace socialist feminism's lineage back to this early organizing? Why aren't Canadian socialist women cited as inspirations? What conditions gave rise to Canadian socialist feminists' analysis of women's oppression? What historical socialist tendencies did socialist feminists draw on? Furthermore, how were organizational norms different in early socialist organizing and later socialist feminist organizing? This chapter reviews the early history of socialist struggle in Canada ${ }^{17}$ and its political influences leading up to the emergence of socialist feminism in the 1960s. In particular, I focus on how the 'woman question' was understood by socialists. The phrase "woman question" was a shorthand way to refer to the various debates on the origin of women's oppression and what to do about it. My hope is that by outlining early socialist women's contributions, the reader will see how socialist feminists shared some analysis with early organizers, how their efforts were distinct from early organizing attempts, and how the political divisions between socialists in the 1960s and 1970s arose out of some of the earlier debates in Canada about the legacy of socialism and communism in practice, i.e. in the Soviet Union and China. This

\footnotetext{
17 This review does not focus on historical developments in Québec which, while similar, advanced in different ways given the national question.
} 
perspective is important as it helps explain how socialist feminism got its roots and what socialist traditions its leaders have drawn on. It contributes to one of my main conclusions that socialist feminism is distinct from early socialist organizing in analysis and practice and distinct from the socialism espoused by the Communist Party of Canada, Communist Party of Canada (Marxist-Leninist), and other Maoist and Marxist-Leninist organizations.

The questions of women's emancipation and socialism have long been tightly connected. ${ }^{18}$ All socialist women shared a common conviction that capitalism was the root cause of their oppression, while differing considerably in their goals and tactics. Some advocated for reforms to capitalism and others its complete overthrow. But there were issues that set women apart from their male comrades. These issues - the so-called woman question - concerned how to understand and fight women's oppression in capitalist society.

To cover this history, this chapter is divided into four sections. In section 2.1, I briefly discuss the general outlook of the first socialist parties and organizations and their approach to the "woman question." The women in these parties largely focused on their roles as maternal figures who were to raise socialist children and support their husbands' struggles in their labour force. In section 2.2, I show how this attitude began to change with the rise of the Russian Revolution and the emergence of the

\footnotetext{
${ }^{18}$ For instance, the first International Women's Day events were organized by the Socialist Party of America in 1909. In 1910, the International Socialist Woman's Conference proposed a Women's Day be held annually. The Russian Soviet Federative Socialist Republic was the first state to declare International Women's Day a national holiday, in 1918. In 1922, Clara Zetkin brought a proposal for IWD with her to the Third International (Kaplan 1985). From that "time on International Women's Day ...became a communist holiday" (Kaplan 1985: 165). In 1955, a false origins story was created to divorce IWD from the Soviet Union and the USSR (Kaplan 1985). The story goes that IWD was born in celebration of a New York garment strike in 1857. This strike never happened (Kaplan 1985).
} 
Communist Party of Canada. In section 2.3, I examine depression-era organizing and the rise of the Cooperative Commonwealth Federation and Trotskyism. In section 2.4, I talk about the period around the Second World War, and how the death of Stalin in 1953 and subsequent focus on the People's Republic of China as revolutionary model impacted the socialist movement in Canada. This political shift helped to define much of the politics that emerged in the 1960s, including socialist feminism. This broad history offers important context for understanding the innovations made by socialist women and how political divisions on the Left shaped their emergence. In particular, it shows how early divisions in the socialist movement (Marxist-Leninism, Trotskyism, and Maoism) led to later divisions between socialist feminists and socialist women who were organizing in the Communist Party of Canada, Communist Party of Canada (Marxist-Leninist) and other organizations.

\subsection{Canada's Industrial Advancement and Early Socialist Organizing}

From Canada's founding, its ruling circles relied on the external flow of capital from British and American sources. Constituted as a Dominion of the British Empire in 1867, Canada began to gain formal control over international matters only following the First World War. British finance and commercial capital played a disproportionate early role. Tom Naylor (1975a) argues,

Canadian governments historically showed an almost paranoid sensitivity to the state of Canadian credit in London. Confederation itself was little more than an elaborate exercise in public finance. And subsequent government policy was directed at maintaining and improving the state of confidence 
Confederation had introduced into the minds and pockets of British financiers (254).

Industrial capital flows to Canada, however, were a primarily American affair and began to assume greater importance in the $20^{\text {th }}$ century, sparking debates over tariffs with the southern neighbour. The 1911 election loss of the Laurier Liberals to a large Conservative majority is blamed by some historians on the Liberals' negotiation of a free-trade (then called reciprocity) treaty with the U.S., which was subsequently shelved (Naylor 1975b). These frequent disputes bring to mind John A. MacDonald's 1881 remark that "Canada must belong either to the British system or the American system" (Naylor 1975b: 285). While the "Canadian financial system was largely a British branch plant," industrial investment lagged and was reliant on U.S. capital (Naylor 1975b: 284). This gave rise to a situation in which, in Naylor's (1975b) words, The Canadian economy never fully made the vital transition from commercialism to industrialism...Lack of integration between commerce and industry reflected the ease of access to external sources, and this obviated any real pressure for the development of policies and financial institutions appropriate to domestic industrial development, or any desire or need on the part of the dominant strata of its capitalist class to change their colonial position (284).

Nonetheless, by the $20^{\text {th }}$ century Canada began to industrialize with relative speed, in part owing to increased U.S. investment.

From 1896 to 1914, Canada's economy was among the fastest growing in the world (Brown and Cook 1974). The benefits of this economic growth were not 
distributed evenly. Canadian labour historian Irving Abella (1978) noted that "If, as Sir Wilfrid Laurier said, the twentieth century would be the century of Canada, by the end of the first decade of the new century it was already apparent that it would not be the century of the Canadian working man" (3). The same was doubly true for working-class women, Indigenous peoples, and the people of Quebec. Throughout all of this time, Canadian governments flagrantly violated Treaties earlier negotiated between the Crown and Indigenous nations, and displaced Indigenous peoples, to secure their territories for private profit and Canadian nation-building (Hall 2011).

Rural areas in Canada were dominated by resource extraction: logging, trapping, fishing etc. ${ }^{19}$ Mid-twentieth century many of those previously employed in these seasonal industries worked on infrastructure projects (dams, roads, etc.) before moving into small towns. In the cities, living and working conditions were difficult; overcrowding, poor sanitation, and inadequate housing were the norm (Weaver 1977; Plummer 2008). Developments in production and machinery did not lighten workloads. Rather, factory work was difficult on the mind and body. Advances in technology were pursued to increase the productivity of labour, and hence the surplus value extracted from workers, by allowing capitalists to take more for themselves during the same working day (Marx 1990 [1867]: 492). Wages varied based on gender, race, and nationality, though they were inadequate for almost all. Racism and sexism became divisive issues amongst the working-class, who saw that

\footnotetext{
${ }^{19}$ Staples theory explains Canadian economic development as the result of the trade of these staple commodities. The theory was developed by Harold Innis and William Mackintosh and later expanded by Mel Watkins. Watkins (2018) prefers to use "extraction empire" which highlights "the terrible colonization within Canada of Indigenous people" and "the wounding of the planet, the violation of nature as technology deeply alters the environment" (n.p).
} 
their pay and work differed based on official and often legally-codified discrimination. Married women were prohibited from working, forcing many to remain unmarried or hide their marriage so they could help supplement their husbands' incomes (PSAC 2015). The poorest and most marginalized women were disproportionately forced into paid labour to ensure the survival of their families.

In 1901, women made up 13.4 per cent of the total documented paid workforce (PSAC 2015). The majority worked as servants, dressmakers, teachers, seamstresses, tailors, housekeepers, launderers, milliners, and saleswomen (Connelly 2015) as they were excluded from higher-paying professions and unionized jobs (Nielson 1944). Women's oppression under capitalism was particular; they increasingly faced exploitation in the workplace by capitalists and, in addition, were primarily responsible for unpaid domestic work including care for children, the elderly, and the sick. Many poor women undertook both paid work and unpaid domestic work, forcing them to abandon their children and household responsibilities during working hours (CBC 1998). Indeed, it was common practice for women to tether their children to a bed or yard post during work, while others were forced to place their children in orphanages (CBC 1998). In some cases, older women provided unpaid childcare for their grandchildren. The state also forcibly seized Indigenous children from their families as an attempt to "assimilate" Indigenous peoples, break up Indigenous communities, and stamp out a culture (Sinclair and Dainard 2016). That being said, many Indigenous people resisted, hid their children, and were able to fight back against assimilation (Logan 2016). 
The values and behaviours of socialists and trade unionists at this time reflected those of a society that shut women out of the workforce and public life and, as I demonstrate in the subsequent chapter, carried well into the $20^{\text {th }}$ century (Baker and Robeson 1981; Klein and Roberts 1974). Socialist and trade union organizations viewed women's employment and organization with suspicion (Kealey 1984). Some of this suspicion can be attributed to the actions of the bourgeois suffrage movements, which were hostile to working-class demands and capitalist reform such as worker control, better wages and benefits (Bacchi 1983).20 Canada's earliest socialist organization, the Canadian Socialist League (CSL), was based on Christianity and its views on gender and family stressed women's importance in the private sphere as homemakers and caretakers (Newton 1995). The CSL was influenced by the work of Edward Bellamy, a prominent American socialist and author whose work, Looking Backward, inspired the organization's struggle for state ownership of industry (Kealey 1984; Newton 1995). On the basis of Bellamyite Nationalism the CSL organized 60 locals across Canada that sought to challenge inequality through education, agitation, and electoral politics (Kealey 1984).

In 1902, the CSL changed focus on several fronts including taking up the call for universal suffrage (Newton 1995). This was made possible in part by the leadership and work of a minority of women within the party committed to understanding the "woman question" and organizing women accordingly. Two

\footnotetext{
20 Bacchi (1983) argues, "the suffragists' behaviour and attitudes...gave labour supporters good grounds for their suspicions. True 'paternalists,' the suffragists found it difficult to let labour do things for itself. They opposed strikes and unionization and recommended palliatives like factory legislation to remove the most blatant evils of the industrial system" (119).
} 
important figures emerged during this time, Margaret Haile and May Darwin, who became involved in the CSL and in its participation in the 1902 Ontario provincial elections (Kealey 1984; Newton 1995; Bradburn 2011). Both Haile and Darwin were involved in women's auxiliaries and the Women's Labor Leagues (Kealey 1984). In these spaces they were part of ongoing debates about how women should best support trade union struggles and the movement for socialism. Darwin began writing for the women's column in the labour newspaper The Tribune to provide a perspective on women's exploitation and oppression within capitalism (Kealey 1984). She also participated in other social and educational work to recruit women into the CSL (Kealey 1984; Newton 1995). Margaret Haile became the first woman to run for provincial legislature, with Darwin's support, chairing and speaking at candidates' meetings (Kealey 1984; Bradburn 2011). Haile and Darwin campaigned on the popular idea that women had a unique place in society as mothers, wives, and caregivers, but also supported women's right to vote and their active participation in the fight for a socialist Canada (Kealey 1984). ${ }^{21}$ Their support for women's rights to vote won them backing from suffragettes and middle-class reformers. However, Haile and Darwin insisted that suffrage would only amount to a partial victory for women and that women's liberation would require the transition to a socialist economy (Kealey 1984). At a CSL meeting Darwin argued that women and children were the greatest victims of a capitalist system that thrived on competition (Kealey 1984).

\footnotetext{
${ }^{21}$ Haile and Darwin were "maternal feminists." Maternal feminists organized around the idea that women had a unique role to play in society as caregivers. Maternal feminism was practiced by women in the bourgeois women's movement as well as by socialists. It is still practiced today, albeit with less frequency.
} 
Through their campaigning, auxiliary and Labour League work, Haile and Darwin educated other women on political economy and how the prevailing economic and political order affected women. They were integral to developing discourse within early Canadian socialist movements around women, recruiting women to the socialist cause, and pushing their party to take a stand on women's issues like suffrage.

Among Haile and Darwin's demands was the establishment of a "family wage" (Kealey 1984), meaning wages adequate to allow working men to provide for their immediate families (wife and children). This demand was pushed by the trade union movement and socialists at the turn of the century as a means to reduce the degree of exploitation of working men, ensure that households could afford basic necessities, and protect women and children from dangerous work (Palmer 1992). Women supported the fight for a family wage, though it was criticized by feminists years later for reinforcing the dominant conception of women's position in the domestic sphere as a maternal figure (Fager and Partias 2005). Women's economic independence was not considered in this or other preoccupations of the socialist and trade union movement. Early socialist organizations, the Socialist Party of Canada (SPC), Social Democratic Party (SDP) and the Socialist Party of North America (SPNA) concentrated on men's labour to the detriment of women's (Kealey 1984). Instead, they supported the work of women's auxiliaries that organized housewives to support working men. These organizations held that encouraging women's waged labour would jeopardize men's wages, and further, that a household should be able to survive on the income of one working man (Segal 1990; Frader and Rose 1996; Palmer 1992). Since there existed no state-funded childcare, this demand for a family 
wage also corresponded to the need to have a caregiver at home to look after young children.

Women's economic independence and suffrage were often beyond the purview of early socialist parties, in part because women were rarely involved in decision-making or formal leadership within these organizations. Those women involved in party work were typically given minor secretarial, administrative and support tasks (Kealey 1984). As well, some women in these parties did not support organizing around the woman question and opposed making the economic and social independence of women an issue (Sangster 1989; Kealey 1984). Women's relative lack of participation in political parties and government in general in the early 20th century also made them underrepresented in socialist politics. However, in the face of all these obstacles women were increasingly organizing and educating themselves in the workers' and socialist movement in Canada.

In 1904, the British Columbia Socialist League and Ontario Socialist League merged to form the Socialist Party of Canada. The SPC prioritized political action over industrial and trade union activities (Kealey 1984). The party called for the transformation of capitalist property into collective property, collective management of workplaces by workers, and focusing production on the needs of people instead of profit (Kealey 1984; Sangster 1989). The SPC's ideas about women were consistent with all early socialist organizations. The SPC contended that women's role as socialists was in the domestic sphere, raising socialist children and supporting their husbands' activities (Sangster 1989). They even portrayed women as "intellectually inferior and inherently conservative" in their paper, Western Clarion (Sangster 1989). 
In Canada, Finnish women in the SPC, however, challenged the party's views on the woman question, and carved out spaces to discuss and organize around the problems women were facing. The Toronto Socialist Women's Study Club (1908-1909), an initiative of women of Finnish origin in the Socialist Party of Canada (SPC) demonstrated women's resilience and commitment to their role in building socialism even when many of their comrades were working against them (Newton 1952). They organized weekly meetings to discuss works of Marx, Engels, and Bebel ${ }^{22}$ (Newton 1952; Kealey 1984), shedding light on women's oppression under capitalism, the importance of women's participation in socialist struggle, and how their lives could change under socialism. August Bebel's book Women Under Socialism (1879) was recommended by party member and women's columnist Bertha Merrill Burns (Newton 1952). Bebel's book affirmed that the woman question was "one of the most important" of the time. The book discussed a range of topics related to the place of women under capitalism, including Christianity, marriage, prostitution, and labour. The book celebrated women's demand for political rights and argued that it was the "duty" of a woman "to defend herself and seize every means she may deem fit to conquer a more independent position for herself" (Bebel 1910 [1879]: 220). Finnish women who organized in the SPC drew on their experiences of oppression and exploitation in Canada and their studies of Marxism and the woman question sparked their determination to fight for their rights and position as party comrades second to none. The Toronto Socialist Women's Study Club carved out a space to discuss political economy and its relation to women's struggles. Dealing with the question of

\footnotetext{
${ }^{22}$ Many of these same texts would be discussed by socialist feminists organizing half a century later.
} 
the affirmation of women, these women applied Marxist theory and conclusions to their work in sewing circles that doubled as union auxiliaries connected with the SPC (Sangster 1989; Kealey 1984). Thus, women's organizing occurred within the context of their oppression by men as a group, including socialist men, under capitalism. Widely accepted social norms, that served capital interests, based on biological understandings of sex/gender and notions of family formation, were the basis for divisions of labour that penetrated organizing and claims, but also penetrated socialist organizations because if confronted, they were considered to undermine men's positions and socialist struggles.

By organizing and educating among their peers and deepening their theoretical knowledge, Finnish socialist women demonstrated the need for the SPC leadership and membership to do the same. Finnish-origin comrades also encouraged the SPC to support the suffrage movement, around which cross-class coalitions were forming (Sangster 1989). While these efforts were seen by some within the SPC as distractions from "real" socialist organizing, the Finnish-origin women's organization argued persistently in favour of suffrage and demonstrated the significance of mobilizing women and taking up their cause (Sangster 1989).

Organizing women to the cause of socialism helped working-class men, who made up the bulk of the movement, as much as it did women themselves. As women grew more active, they became important supporters of working men (Sangster 2000; Frances, Kealey, Sangster 1996). Nevertheless, the SPC membership doubted their importance and these debates came to a head in 1908 at the party's Ontario convention (Kealey 1984). Here, the SPC's Finnish organization "pressed for an 
enlarged platform which would include political reforms such as universal suffrage" (Kealey 1984: 92). Women's issues and the woman question were discussed prominently throughout the convention, but resolutions were repeatedly rejected by the majority of members (Kealey 1984: 92). Though the works of Marx, Engels, Bebel and others argued that the only salvation for women lay in the revolutionary movement of the proletariat, the SPC did not take up this question and further, denied women their place in the leadership of this movement. Defiant women socialists continued to educate women throughout the country. SPC member Ruth Lestor, for instance, travelled around the country with her husband and spoke to women on various issues such as suffrage and organizing housewives and working women (Kealey 1984: 93).

The failure of early socialist movements to recognize the need to organize women was a missed opportunity to strengthen women's class consciousness, and better prepare the whole working-class for what was to come; when the capitalist class, aided by the state, brought women into the workforce at lower wages to divide the working-class and increase profits. Working-class and socialist men, while not the root cause of women's oppression, were partially to blame for women's subjugation. They sometimes undermined women's efforts to organize as the Finnish example above shows. In the labour movement, solidarity often depended on the "particular industrial structure of specific towns and cities" (Bradbury 1987: 31). But, men's "opposition to female labour and to female unionization" is a major factor "which historians have stressed in explaining the low rates of female unionization in the past" (Bradbury 1987: 32). Men did this in a self-serving way to protect their own wages 
and livelihoods. Had early socialist parties organized beyond the maternal feminism that saw women as caregivers or "helpers" to socialist men, they would have been better prepared to fight back. Instead, socialist men and trade unionists took for granted women's economic dependence, seeing it as the norm. They ignored socialist women, like the Finnish women of the SPC, who urged them to consider the woman question and campaign on women's issues. They believed that a fight for workingclass women would put them at further disadvantage. Marx (1974 [1870]) recognized this type of antagonism in Irish and British workers and poor whites and black Americans:

The ordinary English worker hates the Irish worker as a competitor who lowers his standard of life. In relation to the Irish worker he regards himself as a member of the ruling nation and consequently he becomes a tool of the English aristocrats and capitalists against Ireland, thus strengthening their domination over himself...His attitude towards him is much the same as that of the 'poor whites' to the Negroes in the former slave states of the USA...

This antagonism is artificially kept alive and intensified by the press, the pulpit, the comic papers, in short, by all the means at the disposal of the ruling classes...It is the secret by which the capitalist class maintains its power. And the latter is quite aware of this (n.p).

Men fell into this same trap and in doing so became pawns of the ruling class. Fighting for better wages and labour conditions for women would have made it more difficult for capitalists to undercut men's wages and labour conditions. It is possible to imagine that the whole working-class movement could have been strengthened and better positioned to fightback against exploitative conditions had men joined in solidarity 
with women. Indeed, it was only after women were thrust into industrial production during World War I, in jobs traditionally held by men, that socialists and trade unionists began to seriously consider the gender relations under capitalist production in Canada.

\section{World War I}

Canada was thrust into the first imperialist world war by default as a Dominion of the British Empire. Canada's participation in this murderous division, partition, and repartition of the world drastically altered the face of labour at home. As poor and working-class men were sent to fight and die in the war, women were called on to fill vacant positions in manufacturing and farming. "Support and substitution" became a popular war slogan of the day. A circa 1914 leaflet released by the Canadian government shows the state's effort to mobilize women into an industrial proletariat during the war:

Support can be given only by substitution of labour. In each case the logical solution lies with the women of each nation. Already English and French women have done nobly. Canadian women are more than willing to do their share in this work which is, by far, the most important of any war work yet undertaken by women. Is it too much to say it is the most important work yet undertaken by either men or women? (Canadian Government circa 1914).

Maintaining production and ensuring a constant supply of munitions to soldiers was the main role that women played in service of the state and industry during the war. While the percentage of women in the labour force did not increase during wartime, the nature of women's work changed. For instance, women's labour decreased in textile industries but increased in munitions factories, with more than 35,000 women 
workers active in the sector (Chenier 2006). Women's entry into the industrial workforce was promoted and glamorized by the bourgeoisie, state, and media. In 1916, the Canadian Imperial Munitions Board produced a book to demonstrate the "practicality" of women's labour "in the production of munitions of war" (Imperial Munitions Board Canada 1916). The book provides photographic evidence of women laboring in munitions factories with commentary about the efficiency of the machines and women's labour (Imperial Munitions Board Canada). In one image, the faces of several women are crudely painted over to depict them as happy and content on the job (Imperial Munitions Board Canada 1916: 60). Women's entry into these industries did not provide better wages, job security or long-term economic independence. They were paid less for their labour than men had been in the same factories, faced harassment and discrimination from employers, and were forced to work long hours in unsafe conditions. Owners of industry, on the other hand, profited greatly from the labour of women, paying them roughly half what men were paid for the same work. The war also affected rural economies, as women were suddenly faced with maintaining family farms alone while raising children (Veterans Affairs Canada 2017).

The Women's Labor Leagues (WLL), formed in 1906, began to gain a foothold during World War I. The Leagues were organized by socialists and women workers who saw the need for an organization to defend women workers and organize women in support of the labour movement (Sangster 2007). Modeled after the British Labour Leagues' auxiliaries (Sangster 2007), the WLL supported equal pay for women, maternity care, birth control, minimum wage laws and other causes (Jones 2003: 14). 
WLL chapters throughout the country raised opposition to World War I and helped educate women, who were fast becoming a contingent of the industrial proletariat. ${ }^{23}$ In Winnipeg, the WLL organized unionized women working in department stores, culminating in a strike against Woolworth's in 1917 (Jones 2003: 15).

In 1917, the Conservative government of Prime Minister Robert Borden passed the Wartime Elections Act, which gave nursing sisters (women with official duties to care for wounded soldiers), and the sisters, mothers, and wives of soldiers the right to vote. Granting the vote for these women was an opportunistic measure made by the Borden government, with the support of the Liberal Party, to firm up support for conscription and strengthen the government's chances of winning the upcoming election (English 2015; Strong-Boag 2016). Nevertheless, it was viewed as a small victory by some suffragettes and it continues to this day to be remembered uncritically as a victory of early feminists. In 1918, Borden extended the vote to some women over the age of 21, but excluded people of Indigenous and Asian descent, who were denied Canadian citizenship. The vote did not fundamentally alter the social and economic conditions of most women, just as it did not, in itself, do so for propertyless men when they were awarded the right to vote. However, it did satisfy some women who had been organizing in the suffragette movement, and many of these women broke their alliances with poor and working-class women after the vote was won (Endicott 2012). Bourgeois women's betrayal of their working-class sisters is repeated throughout Canadian history.

\footnotetext{
23 Efforts of the Leagues to support the trade union movement continued until the 1940s (Sangster
} 2006). 
A prevailing notion is that women's involvement in factory and farm labour during the war altered some of the prejudices about their participation in industry and public life (Bader-Zaar 2017). However, after the war, women faced immense pressure from returning soldiers, socialists, the state, and the trade union movement to leave these industrial jobs. While the number of women in the workplace decreased immediately after the war, by the 1920s it returned to wartime levels (Anderson 2014). As a result, trade unionists and socialists were forced to consider women's labour and the woman question to organize effectively. The prejudices exhibited in the years before nonetheless persisted, and organization among women was weak.

\subsection{The Russian Revolution and Leninism in Canada}

The socialist movement in Canada was galvanized by the 1917 Bolshevik Revolution. Fundamental tasks of the USSR were to change the relations of production, industrialize the country, bring the whole population into to the process of socialist construction, and defeat the political forces in the country opposed to socialist development (Rowley 2015). The USSR ushered in the largest political experiment in socialist economic development the world had seen, with significant implications for women (Rowley 2015; 2019).

The new Soviet state prioritized involving women in the construction of a new socialist state and pioneered many advances in women's rights. Immediate reforms included equal pay and maternity leave for women; lighter work during pregnancy with no loss in pay; outlawing of night shifts and overtime work during pregnancy and for women with children; implementation of paid breaks for working and nursing 
women; legalization of divorce; and lowering of the retirement age to 55 (Rowley 2015; 2019). Shortly after the 1917 revolution, the Secretariat of the Central Committee of the AUCP(b) also established a women's department, the Zhenotdel, that encouraged women to become leaders in the Party and for the socialist cause (Goldman 1995). It also encouraged women's education and went to great efforts to spread literacy among women workers and peasants. ${ }^{24}$ In 1920, through the efforts of women in the Women's Department, the Soviet Union also became the first country in the world to make abortion legal and available in state hospitals (Rowley 2015). The Zhenotdel also founded a magazine, Rabotnitsa (women worker), whose target audience was working women, and it was distributed widely in factories and libraries (Romanenko 2012: 3). The magazine provided cultural and educational information on issues that were relevant to women workers and identified as important by the Zhenotdel and AUCP(b) (Romanenko 2012).

The 1930s saw material advances for Soviet women, along with serious setbacks in the realm of rights. While women were working at greater rates, and in far more diverse professions, than anywhere else in the world, they often bore the double burden of motherhood and work. Pushback, including from some Soviet women, against a more liberal approach to family issues, as well as a relatively conservative Party leadership, led to retreats on decriminalization of homosexuality and abortion (Goldman 1995). ${ }^{25}$ This turn came with greater emphasis on the Soviet

24 The Zhenotdel was eliminated in 1930 after "being weakened by a lack of support and funding through the 1920s" (Goldman 1995: 338).

25 Siegelbaum and Andrei Sokolov (2004) discuss the prevailing views at the time:

A great many comments [on the Soviet draft constitution] came in with respect to articles 120 and 122 , which concerned the rights of the elderly and women, family problems, and the protection of motherhood and childhood. This was undoubted a reflection of the social and 
family, penalties for absentee fathers, and additional material supports for mothers (Goldman 1995). The latter was still seriously insufficient, given the poverty and scarcity which persisted into the 1930s in the USSR, and the overwhelming state focus on development of heavy industry. For instance, a shortage of kindergartens and nursery schools persisted through the 1930s (Siegelbaum and Sokolov, 200).

Abortion access was limited in the early 1930s, and in 1936 it was recriminalized, except in "cases where the continuation of pregnancy endangers life or threatens serious injury to the health of the pregnant woman and likewise when a serious disease of the parents may be inherited" (Decree on the Prohibition of Abortions 1936). The bill that limited abortion access also ushered in further assistance to young mothers, including the establishment of more government aid to larger families, the extension of maternal homes, nurseries, and kindergartens, and an increased penalty for men trying to avoid paying alimony. The Soviet government made this decision, in part, in an attempt to strengthen the family and increase population growth (Krupskaya 1936). Outlawing abortions was justified by the government on the basis that the building of socialism had improved the material

demographic problems that worsened during the 1930s. The experimentation in the preceding years in the realm of family and marriage was attributed by many as the reason for an increase in divorces, a flippant attitude towards family duties, and a drop in the birthrate. So concerned was the leadership about these developments that it decided to take measures, including the adoption of new laws, aimed at strengthening the family's foundations. True, in keeping with the spirit of the times, administrative bans and coercive elements were incorporated into these measures (156-157).

Additionally, figures show the negative effect of the abortion ban on women and children's health: In 1935 the mortality rate was 146 infants per one thousand newborns, whereas in 1938 it was $162 \ldots[$ []n 1935, before [the decree prohibiting abortion] was adopted, 1,932,305 abortions were performed in the country. After the resolution there was a sharp drop, and then another upswing: 570,000 in 1937, 685,000 in 1938, and 755,000 in 1939. And these figures reflect only officially recorded abortions (200). 
well-being of women (Krupskaya 1936). ${ }^{26}$ Nevertheless, outlawing access to abortions had a negative effect on women's health, leading some women to seek illegal methods of terminating unwanted pregnancies. Historian Wendy Goldman (1995) writes, "after 1936, doctors saw an enormous increase in the numbers of women suffering from infections, peritonitis, perforation, hemorrhage, chronic inflammation, sepsis, infertility, and other complications. The death rate from illegal abortion soared" (294).

While the setbacks for Soviet women in the 1930s were dire, they did not amount to a complete rollback of women's gains, either in the workplace or as women and mothers. To Canadian women workers in the 1930s who were watching these developments, policies around abortion and homosexuality were not primary concerns. It was not until the 1960s that the fight for access to abortion became an integral component of the feminist and socialist movements in Canada. To call the results for women's rights "mixed" risks glossing over the real hardships caused by re-criminalization of abortion. At the same time, the historical record does not support the idea that the Stalinist period resulted in erasure of those gains, or the Soviet state giving up its aspirations towards women's rights (Petrone 2004; Ashwin 2000). Indeed, it continued to be an inspiration for some socialist and communist women in Canada, who enjoyed comparatively poorer state support as women and mothers.

\footnotetext{
26 The 1936 Soviet Constitution accorded women "equal rights with men in all spheres of economic, state, cultural, social and political life." The Soviet Union guaranteed these rights "by affording women equally with men the right to work, payment for work, rest and leisure, social insurance and education, and...the state protection of the interests of mother and child, maternity leave with pay, and provision of a wide network of maternity homes, nurseries and kindergartens" (Constitution of the USSR 1936).
} 
Viewed from abroad, socialist women saw for the first-time what women's rights might look like in a socialist country and how they could be realized. In Canada, reports from the Soviet Union were treated with much interest and sympathy by a broad spectrum of the left (Sangster 1989: 28), and Soviet reforms in "marriage, divorce, and abortion laws fostered similar debate in Canada, opening up women's issues which had rarely been discussed by early socialist left" (Sangster 1989: 28). Taking the lead from the USSR and the Communist International, Canadian communists acted to increase women's involvement in socialist organizing.

\section{Communist Party of Canada}

The Communist Party of Canada (CPC) was founded in 1921 by those inspired by the Russian Revolution who saw the need for a Party of the "new, Leninist type" in Canada, that would work systematically for revolution and social transformation (Sangster 1989). The CPC brought with it "new parameters of thought and action" on the woman question in Canada (Sangster 1989: 26). Its efforts to organize women led it to establish its own Women's Department, re-establish the Women's Labor Leagues, which had faltered after the war (1923), and launch publications aimed at educating and recruiting working-class women to the socialist cause. Efforts were also made to unionize working-class women.

In 1922, the CPC founded its Women's Department under the guidance of its first director, Florence Custance, with an aim to organize working-class women and housewives through education and involvement in trade unions (Sangster 1989: 33). At the time, only one per cent of women were union members, and many worked without any legislated protection (Sangster 1989:34). Publications issued by the 
Women's Department (circa 1922) reported that the number of women in the trade unions in 1921 was 4,070 (n.p).

In 1923, in an effort to address this weakness and under the guidance of the Women's Department, the CPC restored the Women's Labor Leagues (WLL) that had fallen into disarray following the end of the First World War. The CPC did not exercise control over the WLL but were a major influence on its discussions and decisions through women party members. The stated goal of the WLL was to address two practical questions confronting the socialist movement in Canada:

1. How to attract women to active participation in the everyday struggles for better conditions of labor and higher wages.

2. How to combat the "reactionary influences" which hold working-class women in their grip...and how to take them forward to revolutionary class action and organization (Custance 2015 [1924]: n.p).

A common idea in early socialist parties that also held sway in the CPC was that women were disproportionally influenced by bourgeois ideas. Women workers were portrayed in "mass media as temporary workers concerned with shopping and beauty, and...[the] pursuit of a husband" (Sangster and Hobbs 2000: 38). While these influences did exist, the idea that women were more influenced by them was rooted in male chauvinism and did not accord with the reality that women were often key behind-the-scenes organizers of socialist organizations and trade unions (Sangster 1989; Endicott 2012). Nevertheless, the WLL was an influential and effective force to combat these influences where they existed. By 1924, the WLL had eleven branches across the country (Endicott 2012: 158) and by 1927 had added an additional seventeen (Sangster and Hobbs 2000). Women within the Leagues took part in 
organizing various events, demonstrations, and labour conventions, and participated in lobbying and fundraisers across the country (Sangster 1989). This included organizing the wives of unemployed workers into the unemployment movement, supporting strike struggles, creating and distributing propaganda for the trade union movement, and supporting Old Age Pensions, Workmen's Compensation and Mothers Allowances. Women also collected funds for striking workers, including steelworkers, needle trades workers, and miners (Sangster 1989; Endicott 2012; Buhay n.d.-a). The WLL also took part in organizing the first International Women's Day events in Canada, which focused on the struggles of women workers, and solidarity with the Soviet Union (Endicott 2012; National Women's Department 1931b).

In 1926, the Woman Worker was published to help the Women's Labor League Movement spread its message (Sangster and Hobbs 2000). It was the first Englishlanguage women's socialist magazine in Canada and dealt with various subjects affecting working-class women, including strike struggles, job insecurity, militarization of schools and public life, housing conditions, unemployment, and poverty (Sangster and Hobbs 2000). About the magazine, its first editor, Florence Custance, wrote:

The Woman Worker is the voice of the Women's Labour League Movement. It will tell what our movement is doing to help raise the standard of life for women workers. It will deal with domestic, industrial and political problems affecting the lives of working women. It will endeavor to speak truthfully about these struggles so that those who hear our voice will have confidence in it... (Quoted by Sangster and Hobbs 2000: 33). 
The target audience of the paper tended to be working-class housewives and mothers, seen by Custance and the CPC as susceptible to capitalist ideology and 'middle-class' moralism (Sangster and Hobbs 2000). Articles focused heavily on housewives, to the neglect of women who also worked in paid employment (CPC n.d.b). While some effort was made to keep the magazine in touch with the lives of working women, and articles were published in support of the trade union movement, the magazine and WLL found themselves at odds with the CPC and International Communist Movement on this question as the former's primary focus was on housewives and not working women (CPC n.d-b). Indeed, social norms designated housewives to see themselves this way and men took great pride in having a woman at home who was doing mostly unpaid work. Women often hid the paid work they did at home from others (i.e. childcare, sewing, ironing, bookkeeping and much more).

The Women Worker succeeded in its critiques of state-supported women's organizations such as the International Order of the Daughters of the Empire (IODE). The IODE organized in support of British imperialism and put forward reactionary positions on trade unions and workers' organizing (Sangster and Hobbs 2000: 102). In the Woman Worker's first issue alone, three separate contributions challenged the widely-publicized positions of the IODE (Sangster and Hobbs 2000). One section of Woman Worker was devoted to "Correspondence from Working-class Women," publishing letters from women readers about their struggles and successes and calling on others to contribute (Sangster and Hobbs 2000). One submission told the story of Ellen Kenealey, who committed suicide due to the poverty and abuse she was 
forced to endure as a cleaner (Sangster and Hobbs 2000: 29). The article read, the “women who employed her expected her to get through a week's work in a single day. She hated them for their heartlessness. But, then, again, when there was no work, she faced starvation" (Sangster and Hobbs 2000: 29). These submissions illustrated the hardships that working women faced in the workplace and in the home.

A noteworthy contribution of the Woman Worker was its commentary on race and ethnicity in an era where "racist and class-based fears about the declining white population and increasing presence of southern and eastern European immigrants" was rampant in the trade union movement and among the Anglo-Canadian middleclass (Sangster and Hobbs 2000: 72-73). While it lacked substantive analysis on race and ethnicity, the magazine was one of few publications that offered an analysis of racial divisions. It argued that "racial divisions were manipulated by employers to prevent working-class solidarity" in a time where almost all trade unions were opposed to immigration from non-white countries (Sangster and Hobbs 2000: 39).

As Women's Labor Leagues continued their work, ideological and strategic differences between the Leagues and the Communist Party became more obvious. These differences resembled the debates between anarcho-syndicalism and communism. The WLL "drove home the point again and again that the very best protection for the working-class people under capitalism was the union, not the government" (Sangster and Hobbs 2000: 77). The communists supported these struggles but emphasized that "good wages and secure futures" could only be "guaranteed by a socialist economy created and controlled by the working-class" (Sangster and Hobbs 2000: 77). 
Differences between the Communist Party and Communist International, and the Women's Labor Leagues culminated in 1929 when Custance and the CPC Women's Department were criticized by the Communist International for overemphasis on organizing working-class housewives while doing little to organize proletarian women (Endicott 2012: 159). The Comintern blamed the CPC for its lack of leadership and supervision of the projects undertaken by its Women's Department. Custance, the Comintern argued, led the Women's Department and the Women's Labor Leagues in a direction that was "too conciliatory to other women's organizations, giving air to reformist arguments, rather than condemning them while promoting the view that true emancipation for both sexes could only come with the end of capitalism" (Endicott 2012: 159). The CPC was forced to re-evaluate its political direction, and debates within the party raged around what was to be done to organize women (CPC n.d.-b). The CPC released a statement that read:

The orientation of the Director of the Women's Dept. has not been based on winning the masses of working women for the revolutionary movement, it has been rather an orientation of conniving stratas of the petit bourgeoisie. The approach has been mainly to housewives while little has been done towards reaching the masses of organized and unorganized factory women, and we have looked upon the Women's Labor Leagues as practically our sole basis for this work. The propaganda put forth has been petit-bourgeois, pacifist in character, impermissible in the Communist party (as quoted by Endicott 2012: 159).

The same year (1929), Custance died at age 48. Alice Buck became the new leader of the WLL and a new executive was chosen based on an emergency meeting in Toronto of two locals (Endicott 2012: 160). The process was seen as undemocratic 
as it excluded the 58 other groups affiliated with the WLL (Endicott 2012: 160). Of the "sixty local groups affiliated to the [WLL]...only four were English-speaking (Toronto, Calgary, Vancouver, and Regina), and two Yiddish (Toronto and Montreal), and the rest, representing 98 per cent of individual membership, were Finnish and mainly centered in Sudbury and other parts of Northern Ontario" (Endicott 2012: 160). This caused outrage from a number of members. It was a point of contention in the years to come around representation and the grievance with the central WLL leadership in Toronto (Endicott 2012). With Buck as the new leader, the WLL was closer politically and organizationally to the CPC leadership (Alice Buck's husband, Tim Buck, also became the party's general-secretary that year) (Endicott 2012: 160). Following Custance's death, the party's Women's Department was led by Becky Buhay, a prominent leader of the WLL who had defended Custance and did not shy away from criticism of the leadership of the CPC and the Leagues. Debates continued among communists around the role of housewives and working women in the years to come..$^{27}$ Some communists maintained that housewives were closely aligned with petit-bourgeois/middle-class interests while others argued that they aligned politically with the working-class. Buhay would later become the leader of the CPC's National Women's Department. Under her leadership, the National Women's Department (1931b) called on housewives "to join with working women in the shops in the struggle against unemployment" and poor working conditions. They also

\footnotetext{
27 While there are important debates and considerations about the strategies for organizing women within the workplace versus the home, the idea that housewives were not "working women" neglects the fact that many were involved in paid piece work, childcare, farming, food processing, logging, exchanges with other households, and other forms of work. This work helped create a sharing economy that propped up capitalism.
} 
distributed propaganda that pointed out "the miserable lot of the housewife" and of the "discrimination against married women working" (Women's Department 1931b).

\section{Canadian Trotskyism}

In the late 1920s, a Canadian Trotskyist movement was also emerging. In 1928, then-Communist Party Chairman, Maurice Spector, ${ }^{28}$ was expelled from the CPC for his endorsement of Trotsky's Left Opposition after attending the Thirteenth Conference of the Communist Party of the Soviet Union in Moscow (Spector 1928). The Soviet Left Opposition was partly rooted in Trotsky's disagreement with Stalin's position on "socialism in one country." This debate began in the early 1920s after the defeat of several proletarian revolutions across Europe (including in Germany, the most developed capitalist country on the continent at the time). The debate over "socialism in one country" versus "permanent revolution" concerned the external orientation of socialist states: should they devote their energies towards stirring up revolution in other lands, or pursue an international strategy focused on achieving stability and breathing room? While the former would require expenditure of resources to support external revolutions, the latter aimed to facilitate socialist development in one country in a way that would support the revolution internationally in the longer-term. The Soviet and others' strong focus on the latter was seen by Trotsky and his supporters as a betrayal of socialist ideals, and profoundly conservative (Trotsky 1996 [1937]). Trotsky (1996 [1937]) later

\footnotetext{
${ }^{28}$ Spector was celebrated by members of later Trotskyist organizations that were active in the 1960s - 1980s. As we will see, the debates of the 1920s between Trotskyists and mainstream Communists had a major effect on how divisions in the left throughout the 1960s and 1970s played out including in socialist feminist circles.
} 
characterized socialism in one country as the "sterile and unhistoric notion that, thanks to the natural riches of the country, a socialist society can be built within the geographic confines of the Soviet Union" (n.p). Trotsky and his followers maintained that the dictatorship of the proletariat in one country could not last in a reactionary Europe.

Trotsky and the Left Opposition correctly noted that their position was more closely in line with Marx and Engels' theories about revolution, including Marx and Engels' commentaries on how the Paris Commune would quickly be overturned by surrounding countries without being matched elsewhere. Stalin (2008 [1926]), on the other hand, taking his cue from certain observations made by Lenin, argued that "under the dictatorship of the proletariat we possess...all that is needed to build a complete socialist society, overcoming all internal difficulties, for we can and must overcome them by our own efforts" (n.p). Completely developed socialism, for Stalin (2008 [1926]), was possible in one country, but "the final victory of socialism" would entail revolutions outside of the USSR which would "guarantee against attempts at intervention" and attempts to restore capitalism (n.p.).

Trotskyists in Canada, as elsewhere, saw socialism in one country as a deviation from "the previous Bolshevik commitment to world revolution and internationalism" (Palmer 2005: 95). They blamed this deviation for what they saw as the "the growing apparatus of Soviet repression, and the decline of anything resembling a communist culture, intellectually and politically" and the imposition of Soviet positions on other national communist parties worldwide (Palmer 2005: 95). Palmer (2005) argues that "programmatically this reduced the Communist 
International to a merely auxiliary body, a guardian of Soviet well-being, rather than an arm of revolutionary internationalism" (112).

This, and other differences in theoretical and historical appraisals of the USSR and other socialist states also led to differences in how Trotskyism characterized those countries. While Soviet-aligned parties saw the USSR and Eastern Bloc countries as progressive, socialist countries that must be defended, and Maoist parties said the same of China, Trotskyists saw these countries as deviating from a socialist ideal. Before his murder, reflecting on the brutalities of the Soviet experience in the 1930s, Trotsky characterized the Soviet system as "not a socialist regime, but a preparatory regime transitional from capitalism to socialism" (Day 1973: 192) or a “degenerated workers' state” (Trotsky 1938: n.p). Following this analysis, Trotsky's followers took up and advanced this theoretical critique. Further splits occurred within Trotskyism over the question of whether Soviet-style countries were “workers' states" at all, or "state capitalism." In the 1970s - 1980s, two major opposing strands were represented by Ernest Mandel, who upheld Trotsky's degenerated workers' state analysis, and Tony Cliff, who advanced the concept of “bureaucratic state capitalism" (Harman 1990). This was not unlike the split between Soviet and Chinese-aligned communists, each analysing the other's favoured country as state-capitalist.

These debates came to shape the Trotskyist movement in Canada, including the organizations that socialist feminists helped to found and lead. As I describe later, some socialist feminists continue to cite this debate in the movement as significant to their political lives. Indeed, it was on the basis of opposition to Stalin and socialism in 
one country that the Trotskyist movement developed. In 1932, Spector became a founding member of the International Left Opposition (Trotskyist) Canada (ILO). Despite Spector's former prominence in the $\mathrm{CPC}$, the Trotskyist movement during the late 1920s and into the 1930s was "unable to secure itself a footing in Canada" and the Communist Party continued to be the dominant force on the radical left (Palmer 2005: 136).

\subsection{Depression-Era Organizing and the Founding of the CCF}

On October 29, 1929, the New York Stock Exchange crashed and the worst economic crisis of the twentieth century enveloped capitalist countries. In Canada, industrial activity fell, production levels declined, wages were slashed, and the unemployment rate skyrocketed. Life for working-class families became a matter of daily survival and hunger, homelessness, and unemployment affected thousands of Canadians (Struthers 2013). Mass unemployment meant that once again, women's participation in the workforce (especially married women) was challenged, as “considerable sections of popular opinion...returned to the view that a woman's place was in the home, and that women ought to be obedient to men" (Endicott 2012: 166).

The average weekly wage for women dropped from \$12 in 1926 to \$9 in 1930 and many women were forced out of the labour market with layoffs and dismissals (Endicott 2012). On the other hand, in some instances, employers were keen to hire women as a source of cheap labour during the Depression. Women were often paid 50 per cent less than men for the same work (Endicott 2012: 166). It therefore became advantageous for employers to "lay off men, only to rehire women at a lower rate" (Endicott 2012: 166). This was particularly prevalent in the textile industry and 
the needle trades (Endicott 2012: 166). In this context, the work of communists during the Depression was integral to uniting women and men workers in the fight for better working conditions.

The CPC rejected the widespread idea that women were to blame for taking the jobs of men in factories. In 1931, CPC Women's Department head Becky Buhay sent a memo to all district women's committees and executive committees saying:

We must combat the ideology that married women are responsible for much of the unemployment by taking the place of men workers and must fight against any attempts forbidding married women the right to work. We must also combine with our slogans on unemployment, the slogan of Equal Pay for Equal Work for all women workers and equality in relief measures (as cited by Endicott 2012: 167).

At the same time, by the 1930 s, women's organizing by the CPC was still seen as woefully undeveloped. In Buhay's (n.d-a) opinion, the CPC needed to do more to organize women. While attempts had been made to set up departments, initiate campaigns, and issue shop papers, Buhay argued the CPC's main shortcoming was the failure to overcome their "isolation from the masses of women workers in the factories," and thus lead "working women in economic struggles" (Buhay n.d.-a). "Outside the Needle and Trades," she argued, the CPC "attempted no real trade union activity" amongst women (Buhay n.d-a). Furthermore, she argued, there was a failure to understand "that the work among women was the work of the party as a whole" and should not be left only to district women's departments (Buhay n.d-b [circa 1931]). 
At this time, the slogan "equal pay for equal work" was being taken up throughout Europe. In 1930, the International Trade Union Conference of Women Workers held in Moscow stressed that all working-class women in capitalist economies were affected by the world crisis and urged women workers to use the slogan in their organizing work (Endicott 2012). The delegate report from the CPC emphasized the need for international solidarity among workers (Endicott 2012; CPC National Women's Department 1931). It concluded that an important lesson for the Canadian working-class was to draw women "into the revolutionary unions," then being established under CPC leadership, and that the best way to do this was "under the leadership of the Workers Unity League" (WUL), a militant trade union umbrella organization (Endicott 2012; Buhay n.d.-a; Collins 1931). In 1931, through the efforts of Buhay the WLL began to affiliate with the Workers' Unity League (Endicott 2012: 161; Buhay n.d.-a) strengthening their ties to the trade union movement.

In 1930, the Women's Labor Leagues sent a delegation of six women workers to the USSR to learn firsthand about the early phase of socialist construction in that country, two years after the first Five-Year Plan ${ }^{29}$ was adopted (Endicott 2012; CPC Executive Committee 1930; Gordon n.d. [circa 1930]). The campaign to send women to the Soviet Union was led by Buhay (Endicott 2012; Gordon n.d. [circa 1930]). The motivations underlying the campaign "were to inspire people with the possibility of

\footnotetext{
${ }^{29}$ The Five-Year Plan, inaugurated in October 1928, introduced central planning in the Soviet economy. While the planning was fraught with difficulties and distortions, and the attendant agricultural collectivization increased conflicts with much of the peasantry, the Plans resulted in rapid industrial expansion. During the first three Five-Year-Plans (1928-40), Soviet GDP grew at 5.3 per cent per year, and industrial output increased by 11 per cent per year, along with significant increases in living standards. As this took place, according to Robert C. Allen (2003), "when the capitalist world was mired in Depression," it elicited keen international interest (153).
} 
having an alternative to the capitalist system and to defend the world's socialist heartland by helping the Soviet Union break out of international isolation" (Endicott 2012: 163). The women delegates stayed for three months, touring the country and studying how the beginnings of socialism in industry and agriculture were accruing benefits to the working-class (Gordon n.d. [circa 1930]). They reported that Soviet production was booming and rapidly expanding in a time where Canada and other capitalist countries saw idle factories and mass unemployment. Annie Whitfield wrote for the Worker, "woman in the Soviet Union is equal socially and economically to man. She receives the same pay for the same kind of work" and "we were greatly impressed by the change that the revolution has brought to women" (Endicott 2012: 164). Canadian workers increasingly looked to the USSR for evidence of how a society could resolve the problems and overcome the contradictions and crises so apparent in 1930s Canada. Workers and supporters of Soviet socialism were eager to hear from the women delegates (Gordon n.d. [circa 1930]). When the women's delegation returned to Canada, more than one thousand workers attended a meeting to greet them (Gordon n.d. [circa 1930]). As working-class militancy and the popularity of the Communist Party grew, the R.B. Bennett Conservative government resorted to increasing repression, including imprisonment and deportation of many Party leaders. Nearly 30,000 people were expelled from Canada during this time, including many trade unionists (CBC 2001). The Bennett government also expelled any immigrants who required public assistance or were unemployed (Molinaro 2011).

In the domestic sphere, women also faced great challenges during the Depression. They were regularly left to care for their families with little to no 
resources. Women began producing at home many of the foods and products their families required that would have previously been bought, increasing their domestic workloads (Baillargeon 1999). To earn extra money, many women took on paid work from home in dressmaking, embroidery, beading, smocking, knitting, washing, cooking, baking, and caring for roomers and boarders (Baillargeon 1999). Interviews conducted by Denyse Baillargeon (1999) uncovered some of the undocumented or informal labour carried out by women in Montreal during the Depression. One woman shared her experiences:

He was making ten dollars a week. We couldn't manage on that. I started to work. I sewed for everybody, I knitted, and I did everything to make ends meet...fifteen cents for mittens, thirty-five cents for socks, a dollar and a quarter for a braided rug. It wasn't a fortune. Although for me, it helped me a lot (Baillargeon 1999:99).

This self-employment of women in Montreal mirrored a phenomenon across Canada. While the Communist Party called on working-class housewives to closely link "their whole activity...with the activities of the working-class...and activities of the women workers in the factories" (CPC 1931: n.p), organizing housewives proved difficult. ${ }^{30}$ Once again, the debate around the role of housewives and the WLL was reinvigorated. In her defense of the WLL, Buhay argued:

The WLL, while consisting in the main of housewives, can play an important role in the economic struggles of the workers. As housewives they feel the full

\footnotetext{
${ }^{30}$ How to organize unpaid houseworkers and paid domestic workers and live-in-caregivers is still an important question today. One of the major obstacles is the isolation of these workers in the home and consequently from other workers. Furthermore, in Canada, live-in-caregivers do not have the right to collective bargaining or filing grievances against employers. Many live-in-caregivers and domestic workers face the risk of deportation if they organize.
} 
effect of the crisis through wage cuts, unemployment, and increased cost of living, and through their organization they can materially assist in building up an effective resistance against the capitalist offensive if, instead of being isolated in the past, they link themselves up with the general stream of the revolutionary movement (As quoted by Endicott 2012: 161).

Despite their links to the WUL, the bulk of the WLL's organizing work continued to focus on educating, politicizing, and organizing working-class housewives to support the trade union movement. The obvious limitation was that housewives had no direct influence in the workplace, no ability to stop production, and they could only play a supportive role to workers (as integral as this supportive role was at the time). Notably, the socialist feminist academic literature that first emerged in the 1960s and considered women's reproductive labour in the home failed to consider this work of the WLL, the positive and negative aspects of focusing on the domestic sphere, and the debates that emerged around this issue not only from Canadian communists but from the international trade union and socialist movements.

Women politicized by Depression conditions participated as workers and militant supporters in various strikes, marches and other struggles through the 1930s. This included strikes by workers at Dominion Rubber Montreal, Empire Cotton Mills, Canada Cottons, York Knitting Toronto, Ontario Silk Knit, Oshawa Auto Workers, and Needle Trades Shops (Copp 1982; Patrias and Savage 2012; Sangster 2014; Parr 1990; McIntosh 1993; Steedman 1994; Canadian Auto Workers n.d.). These strikes were often organized in opposition to job and wage cuts and speed-ups. The Textile Corporation, for example, had its own Research and Efficiency Departments where new speedup methods were concocted. Speedup schemes 
intensified the labour of workers, the majority of whom were women and girls (CPC n.d.). The CPC noted that the textile industry had gone "through an intense process of rationalization" and that it was now common "in many factories for one girl to operate as many as 10 looms" (CPC n.d.). Leading up to these strikes the WLL and Women's Department of the CPC produced specific literature educating women on the significance of better working conditions organized through their unions (Collins 1931). Annie Buller, a member of the CPC, became a notable organizer during this period, leading a general strike for better pay and working conditions for dressmakers in Toronto and helping to organize the Estevan, British Columbia Coal Miners' Strike in 1931, which led to her arrest. Records from the Royal Canadian Mounted Police (RCMP 1935; 1934) indicate that communist women were in leadership roles in various unemployment struggles and many were monitored and faced repression as a result. Women, including women leaders of the CPC played important roles in some of the biggest demonstrations of the Depression period including the Regina Trek, Ontario Hunger March, and Vancouver Post Office unemployed struggles (Buhay 1948:17).

\section{Cooperative Commonwealth Federation}

In 1932, the Cooperative Commonwealth Federation (CCF) emerged as a social democratic party proposing to reform the capitalist system. Women played an integral role in the founding of the CCF and women delegates outnumbered the men at its founding convention (Sangster 2015: 74). Many of the CCF's earliest supporters were women who formerly organized in the WLL and who were involved in the suffrage movement (Richmond 2000: 16). Overall, the women membership of the 
party was a mixture of working-class, middle class, and farm women, which differentiated it from the predominantly working-class and national minority membership of the CPC (Sangster 2015: 80). The CCF had a few committed communist members, including some who also held membership in the CPC or previously were involved, but it remained firmly under social democratic leadership. What distinguished the CCF from the CPC was that it was a social democratic party with some of its more radical members advocating for democratic socialism. In the early days, communists did hold sway in the CCF to the extent that they were able to "successfully [include] important statements on public ownership and calls to 'eradicate all capitalist property and social relations'” (Sangster 2015: 75). The major intellectual traditions influencing the CCF were Fabianism, Christian Socialism, and, like the earlier Canadian Socialist League, Bellamy's cooperative socialism (Sangster 2015; Bacchi 1983). The influence of Fabianism within the CCF meant that the party wanted to advance socialism through gradual reforms over the revolutionary overthrow of the existing state power espoused by the CPC at the time.

On so-called "women's issues" the CCF demanded that the government fund social programs such as childcare and provide economic assistance such as mothers' allowances and maternity leave (Sangster 2015; Richmond 2000). Women in the CCF took part in demonstrations around women's rights, ran as candidates in elections, and produced weekly radio broadcasts to discuss the political and economic issues affecting them (Richmond 2000). While in its early years the CCF did not "include a platform on women's rights in its Manifesto," the call for equal wages was incorporated and became an active and important campaign for women members 
(Sangster 2015: 75). Women within the CCF played an important role in supporting the trade union movement (Sangster 2015: 18). They often organized behind the scenes to fundraise for strike pay, feed workers on picket lines, and take up administrative and organizational tasks. One of the CCF's recruitment strategies was for party members to join women's coalitions, auxiliaries and organizations and introduce them to socialist solutions to address women's issues (Richmond 2000: 24). Because of this and the desire to be involved in the community work being done by other women, CCF members became involved in a number of issues around peace, birth control, and juvenile delinquency (Richmond 2000: 24). Issues of peace, socialism, and pacifism were particularly important to CCF women and many of them joined the Women's International League for Peace and Freedom (WILPF) which called for the "elimination of social, economic, and sexual inequalities, as well as violence, from all societies" (Sangster 2015: 78). The WILPF opposed war and international conflict and saw women as uniquely positioned to promote peace, and therefore advocated for a feminist approach to international relations and policy. This aligned with the position of CCF women whom Joan Sangster (2015) describes as taking a "militant mothering" approach to organizing that mixed socialism with maternal feminism. The latter was an early approach to women's rights that "envisioned a state that embodied maternal values and included real women as active participants" (Kimball 1995: 75). Maternal feminists argued that women's "inherent" role as mothers and caregivers gave them a unique perspective and position to shape society in a positive way. 
Among CCF members there was debate around the role of women's auxiliaries and women-specific groups within the Federation. Some members believed that women's auxiliaries would push them "to positions of weakness and irrelevance" and cited the Liberal and Conservative Party ladies' auxiliaries as examples (Richmond 2000: 44). Others felt that separate women's groups would attract women to the party who otherwise would not join. They also felt that these groups would give women the space needed to discuss issues that might otherwise be overlooked (Richmond 2000: 45). In the end, women's relationship with the CCF and specific women's committees varied from province to province (Richmond 2000). In British Columbia and Ontario, provincial women's committees were formed but in Saskatchewan women joined clubs of mixed membership (Richmond 2000: 47). In the end, whether specific women's groups within the party ended up pushing women to positions of weakness and irrelevance depended on whose opinion was asked (Richmond 2000: 47). However, women were generally underestimated and overlooked by their male comrades within the party. As an example, Joan Sangster (2015) cites an article in the CCF newspaper Ontario New Commonwealth that encouraged the party to recruit women because they were "perfect jewels" at raising funds and loved "playing amateur salesladies at bake sales" (80). This attitude demonstrates the type of discrimination, devaluing, and infantilizing that women faced. They were not valued as important political decision-makers or leaders, but as members that could fundraise and take on roles that were less desirable to men. This issue was faced by women in various political parties to varying degrees. 
The CCF in its early phase was no stranger to working with the CPC. Despite their different political outlooks, the parties worked together closely on several initiatives. For example, in 1935 and 1938 they formed coalitions around support for unemployment and relief camp protests (Sangster 2015: 91). Their cooperation in 1935 led them to form a strong coalition within the Women's Labour Leagues. Together they formed "a Mothers' Day Committee that orchestrated a massive Mothers' Day Rally protesting the relief camps and demanding work and a decent wage for 'our boys'” (Sangster 2015: 91-92). In 1938, the two parties joined again to aid striking postal workers (Sangster 2015: 92). Indeed, women within the two parties often found common ground when they were not feeling supported by their respective parties. This is a clear demonstration of how the differences within the two parties were often deemed secondary by their women membership when it came to immediate struggles or prioritizing women's issues.

The Trotskyist movement also had an early, albeit rocky relationship with the CCF. While its forces remained small and relatively unknown in Canada throughout the 1930s, Trotskyism managed to expand "beyond Toronto, making contacts in Winnipeg, Vancouver, and Montreal" (Palmer 2005: 139). Its relatively small presence was further weakened as several splits took place based on debates about whether, and how, to support the CCF. The first split occurred in the Worker's Party of Canada (WPC), the successor to Spector's ILO, between pro-CCF and anti-CCF members (Angus 1977). In the end, the pro-CCF majority cast itself as the Socialist Policy Group (SPG) and began to operate within the CCF (Angus 1977). Not long after, the SPG was expelled from the CCF, which maintained a no-faction policy (Angus 
1977). ${ }^{31}$ After its expulsion, the SPG reunited with former anti-CCF members of the WPC to form the Socialist Worker's League (SWL) (Angus 1977). The SWL later became the Revolutionary Party (RWP), which later split over the same issue of orientation towards the CCF, and with the same outcome (Weisleder 2018). This pattern repeated itself throughout the $20^{\text {th }}$ century and became a point of contention for socialist feminists. ${ }^{32}$

The international Trotskyist movement was, however, gaining traction. In 1938 the Fourth International was founded in France by Trotsky and supporters from various countries, including Canada (Fourth International 1938). The International was proclaimed as an alternative to the Soviet-led Communist International and was ideologically united by Trotsky's just-published document The Transitional Program which ended with a call for the International's creation. While the Fourth International suffered setbacks and splits during and after the Second World War, including Trotsky's assassination in 1940, it became important for Trotskyists in Canada later in the 1960s and 1970s. It was in these later decades that Trotskyism grew as a movement and had an influence on socialist feminists.

\subsection{World War II and its Aftermath: Changing Views of Stalin}

The Great Depression ended with the onset of the second imperialist world war. To combat labour shortages exacerbated by conscription, a number of campaigns were launched by the Mackenzie King government to recruit women into

\footnotetext{
${ }^{31}$ A no-faction policy meant that people could not organize themselves as a group within the CCF in an attempt to change the political direction of the party.

${ }^{32}$ I explain how this became a point of contention for socialist feminists in Chapter 3 and offer an analysis in Chapter 4.
} 
industrial work, aided by national women's organizations and the press. In 1942, with the war well underway, the government launched the National Selective Service program that required all women ages twenty to twenty-four to register for work (Nielson 1944). The program relocated women from the countryside to cities and industrial centers such as Halifax, Toronto, Ottawa, Hamilton, Peterborough, Welland, and St. Catharines (Nielson 1944). To entice women into wartime work, the federal government and provinces adopted the Dominion-Provincial Wartime Agreement that established fully-subsidized nursery care for mothers working in wartime industries (CBC 1998). The program enabled women to enter the labour force without putting the lives of their children in danger, with the federal and provincial governments splitting the cost.

At its height, approximately 261,000 women were involved in the production of war goods (Chenier 2006). They accounted for "more than 30 per cent of workers in the aircraft industry, close to 50 per cent of the employees in many gun plants, and a distinct majority in munitions inspection" (Chenier 2006). Another 41,000 women served in the Canadian armed forces (Nielson 1944: 11). Women's responsibilities in the armed forces included stenography, transport driving, surveillance, and working as physicians (Nielson 1944). Resistance to the war and war measures was strictly forbidden and in 1940, not long after Canada entered the war, the Communist Party was banned under the War Measures Act (The Canada Gazette 1940). Some of its members and sympathizers were interned in camps and again communist, socialist, and anarchist immigrants were deported. Similarly, the Socialist Worker's League was driven underground. During the period of illegality from 1940-1941, women "led 
dramatic delegations and processions to Ottawa demanding release of imprisoned and interned leaders" (Buhay 1948: 18). When the USSR entered World War II, communists in Canada became enthusiastic supporters of the war and their position changed in Canadian society. By 1945, the Communist Party of Canada reached the height of its popularity. The party ran 68 candidates and received 111,892 votes. ${ }^{33}$

In 1945 the Second World War came to an end. Again, there was a push by the state to have women return to domestic duties and lower-paying jobs to make way for men who were returning from war. Women members of the CCF and CPC returned to demands for equal pay, social programs, and financial assistance for women but instead they were faced with government cuts. Programs offered to women during the war, such as fully-funded public childcare were dismantled, and many nurseries were shut down even though Canada enjoyed a time of relative prosperity following the war. Women protested the closure of the nurseries and organized to keep some running without state funding. In a speech to the House of Commons, socialist Dorise Nielson (1944: 63), argued, "the need for day nurseries was felt long before the war started and will continue to grow...Among the low-income groups, mothers have for a good many years been forced to work, and the need they have for care of their children has always been great." Fully-funded public childcare in Canada has not yet been re-instated, despite considerable struggle.

With the end of WWII, the Canadian state again shifted its focus away from fighting fascism to persecution of communists. The growing hysteria about communism was a direct reflection of the growing influence and prestige of

\footnotetext{
${ }^{33}$ Statistics gathered from the Parliament of Canada's Elections and Ridings website.
} 
communism worldwide following communists' critical role in the war and specifically the prestige and influence of the Soviet Union. Like the period following the 1917 revolution and the Great Depression, many communists, suspected communists and sympathizers were deported, imprisoned, and surveilled (Molinaro 2018; Mackenzie 2001). Citizenship could be revoked or denied by the government based on the political beliefs of immigrants and Canada "preferred to accept refugees from communist countries over refugees fleeing fascist or anti-communist dictatorships" (Molinaro 2011: n.p). Thousands of suspected Nazi or Nazi-collaborator war criminals were given refuge in Canada and seldom faced prosecution for their crimes (Hough 2014).

To complicate things further, "in the mid-1950s, the myth of permanent capitalist prosperity provided the breeding ground for crude myths about communism and the Soviet Union" (Kashtan 1982: 193). This was supported by unprecedented economic growth occurring in many countries in the post-war era, and particularly in Canada and the United States. This anti-communist narrative received an enormous boost after the death of Stalin in 1953. Three years after Stalin's death, following internal power struggles in the Soviet Union, the new First Secretary of the Communist Party of the Soviet Union, Nikita Khrushchev, gave a speech to the closed session of the $20^{\text {th }}$ congress of the CPSU condemning Stalin as a tyrant (Kashtan 1982: 193). The late Italian Marxist Domenico Losurdo (2008) argued that this speech played a greater role in changing perceptions of communism for the worse than Churchill's denunciatory 1946 "Iron Curtain" speech. Likewise, the defection of a member of the Soviet embassy staff in Ottawa in 1945, along with his 
"revelation" of alleged Soviet spies in Canada, proved useful to governments determined to present communism as a threat lurking around every corner (MacKenzie 2001). These events presented considerable challenges for communist and socialist organizers, and arguably led to the further entrenchment of capitalism politically and ideologically in the Canadian consciousness. Such challenges included new political divisions between Canadian communists and socialists, with some defending the Soviet Union and others declaring actually existing socialism to be worse than actually existing capitalism in Canada and other developed capitalist countries. Women within the CPC and CCF were also divided along these lines.

While Canada was able to capitalize on the post-war prosperity of the United States following World War II, many women were again faced with unemployment as men returned to the workforce. No longer favoured by the champions of industry, women faced increased sexist discrimination when it came to finding work. The first signs of post-war instability included increased unemployment and a drop in the value of the Canadian dollar in the late fifties and early sixties (Palmer 2009). Although wages continued to rise during this time, these factors contributed to increased economic anxieties felt by working women and working-class housewives. In an effort to calm growing unrest about the economy (especially during election years) and stimulate growth, Canadian governments spent sporadically on public works such as university infrastructure, vocational training and housing grants. This increased funding to post-secondary education had the effect of opening the universities up to more women. 
In Canada, the popularity of the Communist Party had significantly declined. By 1958, the party ran only 18 candidates and received 9,769 votes, dropping even further in the context of the 1960s (Elections Canada). This huge decline and growing vacuum on the political left was in part a result of the Cold War chill effect on communism from the late 1940s to 1950s and is part of the context of the 1960s new radicalism. Meanwhile, the Trotskyist movement was able to gain some popularity. In 1961, the Socialist Information Centre, based in Vancouver, and the Socialist Education League, based in Toronto, merged to form the League for Socialist Action.

Furthermore, the Sino-Soviet split of the late 1960s further divided communists in Canada between those who supported the Chinese (and preKhrushchev) interpretation of Marxism-Leninism and critiques of Soviet policy, and those who supported the USSR's interpretation under Khrushchev. The organizations arising out of this split alone numbered at least a dozen and are beyond the scope of this project. In Québec, “Marxist-Leninist groups...following the teachings of Mao Tsetung, experienced extraordinary growth, with a membership of almost seven thousand young militants" (Rebick 2005: 18). Meanwhile, many Canadian socialists rejected Leninism and the party form altogether, in favour of new ways of organizing that emphasized collectives and eliminating hierarchies. This new generation of Canadian socialists became known as the New Left.

\section{Conclusion}

This chapter demonstrates that socialist women discussed women's relationship to class, their role as socialists, and the particular problems they faced were being discussed as early as the mid-1890s. Women were important, though 
often ignored, participants in organizing for socialism as well as reforms benefitting workers. Early socialist women embraced maternal forms of feminism that emphasized women's position in the family as homemakers. Only with the founding of the Communist Party of Canada did women's issues begin to be understood differently, as integral to socialism, and as members of the working-class. This included the largest mobilizing effort in Canada to date to organize housewives and working women in distinct, revolutionary organizations. The Cooperative Commonwealth Federation was also important for developing women socialists through their participation in the Women's Labour Leagues, auxiliaries, and labour struggles. While the Trotskyist movement remained small, it was laying the foundations for a larger movement that would emerge in the 1960s and would contribute to the rise of socialist feminism. In the upcoming chapters, I discuss how socialist feminism marked a shift in politics and practice from earlier socialist women's struggles. While socialist feminists understood women's oppression as being structured by the needs of capital and the state, their vision of how to make revolutionary change began to shift under Cold War conditions, from party-centric politics to a focus on movements and coalitions. 


\section{Chapter 3: Political Divisions in the 1960s Left and Women's}

\section{Movement}

In this chapter, I discuss how socialist feminists understood and negotiated these political divisions, beginning with what they thought about the Old Left/ New Left divide. Through my interviews, it became clear that there were varying perspectives on this divide, so I sought to further understand what importance they held for activists. The Old/New Left distinction, though oversimplified, is helpful to capture the essence of the differences on strategy and focus between traditional party-centric politics and the more coalition-oriented approach that arose during the period in question.

In this chapter, I also discuss divisions in the women's movement and how socialist feminists saw the difference between themselves, and liberal and radical feminists. I wanted to understand what socialist feminists saw as the main political differences in the women's movement and what challenges they posed for those trying to work in broad-based organizations like NAC. Lastly, I discuss some of the issues that socialist feminists experienced and the tensions that emerged between activists who saw universities as a valid place of struggle and others who worried that academics focused too much on theory to the detriment of the real movement which, they argued, was outside of academia.

\subsection{Divisions Between the New Left and Old Left}

In the 1960s, growing numbers of people looked towards socialist movements around the world that were championing the rights of workers and formerly colonized peoples. It was out of this fervour that myriad movements, some 
highlighting neglected issues around race, colonialism, and gender, came to be, including socialist feminism in the later part of the 1960s. Communist-oriented liberation movements, some succeeding in taking power, threatened capitalism's hegemony from the 1960s through to the 1980s in Albania, China, Cuba, Vietnam, Korea, Chile, El Salvador, Egypt, Burkino Faso, Tunisia, Angola, Congo, Mozambique, Ethiopia, Philippines, and elsewhere. A growing Black Power Movement in the US was heavily influenced by Marxism and Marxist movements in Asia and Africa. The ideas of Karl Marx, Marxism and of contemporary anti-colonial revolutionaries proliferated in Montreal, Toronto, and Halifax (Austin 2013: 5). Well-known Black Liberationists including Black Panther organizer Stokely Carmichael, Trinidadian Marxist C.L.R. James, and Guyanese Pan-Africanist Walter Rodney theorized revolution, violence, decolonization and other important issues (Austin 2013). Palmer (2012a: 379) writes, "buoyed by the vitality of Québec's 1960s revolutionary nationalism and schooled in the manifestos and radical rhetoric of the U.S. Black Power movement and the escalating demands emanating from African and Asian liberation struggles," militant Indigenous groups also began challenging Canada under the banner of Red Power. In Québec, “Marxist-Leninist groups...following the teachings of Mao Tse-tung, experienced extraordinary growth, with a membership of almost seven thousand young militants" (Rebick 2005: 18). All this political activity was spurred by, and influential with, young people getting involved in politics in Canada, including socialist feminists. 
Demographics in Canada also began to change following a move away from an openly "whites only" immigration policy in the late 1960s. Robbins et. al. (2008) explain:

Pierre Trudeau's federal government changed the laws in order to encourage greater numbers of immigrants and thus meet growing labour demands. As a result, waves of new immigrants from the Caribbean, Africa, and Asia arrived, settling primarily in the major cities. They brought their own political traditions and new political mobilizing energy, especially around issues of immigration, citizenship rights, and anti-racism (Robbins et. al. 2008: 4).

Thousands of people were organizing on a wide variety of fronts, and the exuberance around Maoism and national liberation movements in Quebec was nearly matched in the rest of Canada. The movement against the Vietnam War likewise formed a centre of gravity around which many activists had their start (Palmer 2009). Arguably, the energy and political conviction of the left at this time was among the strongest in Canadian history, and Marxism, in its diverse manifestations, was an ideology with clout.

The Left, however, was changing. New activists were beginning to eschew the Old Left in favour of the New Left. The New/Old Left divide comes up frequently in the literature and can be used in a generational sense or a political one. For the purposes of this dissertation, the Old Left refers to more "traditional" socialist groupings that adhered to democratic centralism or some notion of vanguardism. In contrast, the New Left encompasses groups that embraced new organizational forms like consensus, and prefiguration, or that moved away from traditional party 
structures in favour of looser coalitions and social movements. The New Left also sought to distinguish itself from the conception of socialism associated with the CPC and USSR. However, in practice, the distinction was not always clean-cut; some socialist groups identified with the New Left idea, while others condemned it.

Of my research participants, interpretations were varied about whether they and their organizations were part of the Old or New Left. I've already reviewed some of these differences in Chapter 1. In contemporary analysis, these divisions are still present even when the terms Old/New Left are not. They are present in any analysis that takes a position on hierarchical vs. horizontal leadership methods or party vs. grassroots organization. They are particularly relevant when discussing what is the nature of a political movement and what are its aims, since these different methods of organizing may be better suited for some tasks over others. It is worth highlighting a few more examples here. Some socialist feminists argued that socialist feminists were a part of the New Left, while others felt that they continued in the tradition of the Old Left, still others argued that they were a mixture of the Old and New Left. Some questioned the usefulness of the distinction altogether. Amy Gottlieb, for example, argued that the attempt to draw rigid boundaries in this way ignored some of the commonalities that leftists shared:

The Old Left / New Left distinction is a bit odd, though. I certainly used to think of it that way...I was a member of the Revolutionary Marxist Group (RMG) from 1973 - 1981. Now looking back on it, even though we considered ourselves a part of the New Left, in the sense we were rebelling against the dictates and organizations like the Communist Party that were part of the Old Left, I think, in a sense, we were a continuation of the Old Left...We saw ourselves as a vanguard party and we were going to lead the revolution. The 
RMG was a Trotskyist organization and part of the Fourth International. The ways that I saw us being different is that we had tremendous respect for social movements. Social movements, not just political parties, were important in building momentum for the upcoming revolution...The organization I was involved in was both part of the Old and the New [Left]. There's continuities and discontinuities. In terms of socialist feminism, leaving aside the RMG, there were also ways that it had continuities with the New and Old Left...I'm sort of saying this in a provisional way because I see the Old and New Left thing as an old template and maybe there is something useful with it but I'm not entirely sure. ${ }^{34}$

Kathryn Petersen saw herself as part of the Old Left. To explain the New Left / Old Left distinction, Petersen focused on how organizational methods differed between the groups, particularly the adherence to democratic centralism:

I still think I'm part of the Old Left...[In these organizations] you can have a minority position and keep trying to convince other people. But, once the decision is made, whatever it is, everybody does it. It's just decided and because you have so much in common, the fact that there's this thing you don't agree with isn't that significant. Although, groups do leave the Old Left and form their own group because [something] becomes a splitting issue. But, for the most part, decisions were made and if you did not agree with it - that's fine. ${ }^{35}$

Like a significant number of socialist feminists, Petersen was involved in Canadian Trotskyist formations. Despite their origin in the 1930s movement of Trotsky's followers, many such groups in the 1970s saw themselves as New Left and experimented with New Left organizing methods and theories. At the same time, the

\footnotetext{
${ }^{34}$ Amy Gottlieb, interview with author, December 6, 2018.

35 Kathryn Petersen, interview with author, August 31, 2018.
} 
Trotskyist criticism of the CPC and USSR was not a typical New Left criticism, but one originating in a split among Old Left communists. The Trotskyist presence within socialist feminism continued to adhere to vanguardism and democratic centralism to various degrees, following in this tradition. Petersen describes what some of the New Left approaches adopted by socialist feminists looked like by explaining how the women's movement developed consensus-based decision-making:

In the New Left, consensus had developed. In the women's movement, partly in response...[to men being] so rhetorical and didactic and insisting on everything...mansplaining, taking votes, and shouting people down...Women started thinking there are better ways of interacting with people... ${ }^{36}$

She describes how this played out in a meeting she attended at the daycare centre:

There was one meeting at the daycare centre...they wanted to do something that I thought was totally nuts...they just kept hammering me to agree with them and I told them take a vote. [I said] "if you all want to do it, that's fine. Just do it. But you aren't going to convince me" ...It took about 2 hours... [for me] to leave...So, consensus was a big issue. I think consensus came out of women needing to have a different way to converse and make decisions in opposition to the Old Left. ${ }^{37}$

The notion of consensus failed to resonate with Petersen, although she understood its origins as a response to issues of communication and abuse of power on the Left. Her account highlights dramatically different organizational methods taken up by activists in the women's movement, each with its own strengths and weaknesses. Already, one can see how the differences in opinion between socialist feminists about

\footnotetext{
36 Petersen, interview with author, August 31, 2018.

37 Petersen, interview with author, August 31, 2018.
} 
what constitutes the Old and New Left might lead to political tensions within their organizations. I will discuss this in detail in Chapter 5.

\subsection{Liberal, Radical, and Socialist Feminisms}

The women's movement was revitalized in the 1960s and 1970s (Palmer 2009). In Canada, a growing post-war women's movement displayed similarities and differences from the activism of communist and socialist women in the 1920s - 1950s. While communist, socialist, and liberal tendencies persisted, new radical, lesbian, Indigenous and anti-racist feminisms challenged their understandings of oppression. The presence of new immigrants from the 1960s onward also "strengthened the women's movement and posed serious challenges to existing women's politics" (Robbins et. al. 2008: 4) by forcing many white women to consider how their understanding of feminism left out immigrant and racialized perspectives. Additionally, geographical and political divisions emerged around the issue of Quebec nationhood. All these new perspectives gave rise to further debates on the correct theoretical and practical positions on women's oppression, and the movement became further divided. Despite this, overlap and cooperation within the women's movement was also common. Those who lived through these experiences speak about how difficult solidarity could be. Luxton (2014) argues, "as one of the women engaged in these struggles, I feel that we all had to struggle to overcome these barriers by transforming ourselves and the ways in which we related to others" (163).

Rebick argues that the women's movement in Canada was "unique...in the sense that it was class inclusive...There were, from the beginning, working-class 
women who were very actively involved." 38 Women's participation in political and revolutionary activities on campuses, in the workplace and in their communities had led them to be strong advocates for their own liberation. Many women who were introduced to feminism and socialism this way,

knew little or nothing of earlier Left-wing feminist movements, and, at least at first, had no idea that what they were doing was part of a larger historical movement. They came together in small, locally-based groups, and, at least initially, had the sense that they were inventing their politics autonomously and for the first time in history (Ferguson 2014: 151).

Eventually, they learned that they were part of a broader movement and that "women played key roles in most revolutionary movements, [and that] women's equality was formally supported in most communist and socialist societies and access to education and the labour force was encouraged" (Ferguson 2014: 151). Knowing more about the broader movement, many of them joined existing political parties and organizations or created their own. Some wanted to cut off ties to, and were critical of, existing socialist countries, and the CPC and NDP, while others decided to make common cause.

Feminists faced choices to confront, find common ground around, or put aside their differences in order to work together on issues that mattered to them. The National Action Committee on the Status of Women (NAC), formed in 1971, was one of the arenas where political debates and divisions were regularly fought out. Its mission was to see that the government implemented the recommendations of the

\footnotetext{
${ }^{38}$ Judy Rebick, interview with researcher, August 6, 2018.
} 
Royal Commission on the Status of Women in Canada (established in 1967, with its report issued in 1970). The Commission report on the status of women in Canada provided "167 recommendations for reducing gender inequality across the various spheres of Canadian society" (Morris 2006: n.p). It "included recommendations on updating the legislative system and addressing such critical issues for women as poverty, family law, the Indian Act and the need for a federal representative for women" (Government of Canada 2016). The importance of NAC was brought up in several of my interviews. Rowley argued that "next to the trade union movement, NAC...was the most influential and significant movement of the period." 39 Rebick emphasized that NAC helped ensure there "was a structured feminist movement across the country." ${ }^{40} \mathrm{NAC}$ originally encompassed 30 women's groups but grew to 700 throughout its active years (Anderson and Lambert 2006). This growth brought new demands, new perspectives and new causes that were distinct from the Commission report. Marilyn Porter (2013) describes the differences in groups and perspectives:

In the National Action Committee church groups, the Women's Institute, the Young Women's Christian Association, the National Council of the Women of Canada and many others sat down with radical lesbians and abortion activists and worked to reform legislation for women...There were even self-declared and active feminists in the Progressive Conservative Party. Apart from small groups of socialist and more radical feminists in Toronto, the rest of the Canadian feminist movement was classically 'liberal feminist' (143).

\footnotetext{
39 Rowley, interview with author, January 4, 2019.

40 Rebick, interview with researcher, August 6, 2018.
} 
Porter helps to illustrate just how politically diverse the women's movement in Canada had become and how difficult it must have been for them to work together in one national organization. However, within this diversity of perspectives there was also a sense that feminism meant that all women shared common ground rooted in their oppression - a "sisterhood." This concept of sisterhood would be later criticized for focusing overwhelmingly on the experiences of middle-class white women, often to the disadvantage of racialized, Indigenous, and immigrant women (Dill 1983). Porter (2013) explains,

I was a woman, I too experienced oppressions as a woman, and we used the term 'sisterhood' with no sense of irony. This was before we realized how dominant the white middle-class voice was in the women's movement and before we became sensitive to the depth and degree of differences among women (141).

Nevertheless, for some women, there was a sense that the solidarity between feminists outweighed their political divisions. This meant that allies from different organizations could be called on to help mobilize on various issues despite their differences. Dorothy Smith and Marjorie Cohen explain,

Just working as a feminist meant that you built up networks of many names and references...People of different political views were linked by common experiences or indirectly through connections with others. Feuds divided people but also set in motion counteractive work by those who found themselves torn in two directions (Smith 1985: 3). 
There was a lot of tension [in NAC] between socialist feminists and liberal feminists. But...once you were focused on issues, people came together, and it was good (Cohen 2018). ${ }^{41}$

This solidarity made NAC possible, but at the same time, ideological battles played out in the movement.

Vickers, Rankin and Appelle (1993) argue that NAC went through "three distinct phases of development" (66). In the first phase (1972-1978), NAC operated as "a Toronto-based lobby group almost entirely in the shadow of the Royal Commission" (Vickers et. al. 1993: 66). In the second phase (1979-1982), "the organization was rocked by conflict and crisis until it became clear that no ideological group could dominate" (Vickers et. al. 1993: 66). In the third phase (1983-1988), NAC underwent "a period of institutionalization during which the organization became more regionalized" and underwent rapid expansion as "groups outside the metropolitan area" and "women's caucuses within labour unions" became increasingly involved (Vickers et. al. 1993: 66, 85). During the second and third phases radical, socialist, and liberal feminists' positions were often in conflict. All three feminist tendencies had informal and formal leaders within the organization. ${ }^{42}$ Their political and ideological differences gave rise to debates about priorities, organizational structure, and purpose. For their part, socialist feminists were able to gain some influence in the Left Caucus and with trade union women (Vickers et. al. 1993). Vickers, Rankin and Appelle (1993) credit the work of earlier generations of

\footnotetext{
${ }^{41}$ Marjorie Cohen, interview with researcher, August 26, 2018.

${ }^{42}$ For example, in 1977 the NAC executive was composed of "Lorenne Clark, whose work on sexual violence was well know, was philosophically linked to the more radical feminist elements, and Marjorie Cohen, Laurel Ritchie, and Lynn Kaye advanced socialist feminist and union views" (Vickers et. al. 1993: 85).
} 
socialist women, involved in VOW and the CCF/NDP, as integral to winning this influence and also, preventing "the anti-statist characteristic of US radical feminism from making significant inroads" in NAC and broader women's movement (Vickers et. al. 1993: 51).

Political divisions in the women's movement became especially pronounced when racialized, Indigenous and immigrant women began to form their own political organizations or insisted that existing organizations consider their political perspectives and the distinct oppression they faced. Anti-racist feminists fought to have racism acknowledged in the feminist movement and to understand how it likewise structured the lives of women. ${ }^{43}$ Some of these activists rejected feminism and the concept of a cross-racial "sisterhood" altogether (Rodgers 2016). The term "womanism" was taken up in the 1980 s by some Black women as an alternative that grounds feminist analysis “in ideologies of Black women’s struggle for equality along the lines of gender, race, capitalism, oppression, political activism, and consciousness (e.g. Combahee River Collective Statement, Guy-She)" (Rodgers 2016: 37).

In my interviews, socialist feminists described the main divisions in the movement as "liberal", "radical", and "socialist" feminism. Socialists within the women's movement believed that the entire capitalist system must be overthrown in order to ensure women's emancipation; liberal feminists believed the existing system to be compatible with women's liberation, but women were not yet full and equal participants. Liberal feminists advocated for women's entry into politics,

\footnotetext{
${ }^{43}$ More about these tensions in later discussions of the International Women's Day events in Toronto and the establishment of the Toronto Feminist Bookstore.
} 
corporations, and the ruling class. Their position did change from the older forms of liberal feminism in that liberal feminists in the 1970s began extending their demands to include childcare, equal pay, and even access to abortion (Vogel 1989). In contrast, radical feminists, like socialist feminists, advocated for the complete overthrow of "the existing system" (Adamson et. al. 1988). However, the "system" in the view of radical feminism was patriarchy, not capitalism. Adamson et. al. (1988) explain, "at the heart of [radical feminist] theory is the view that biological differences between the genders - and particularly women's role in reproduction - provide the basis for a patriarchal power structure in which men are dominant" (174). Because radical feminists identified men as the primary enemies of women, radical feminists advocated for women's only organizations, marches, and protests (Rebick 2005). They focused "on the need to withdraw from institutions that perpetuate male domination - in particular those in the private domain, such as the family - and define radical alternatives" (Adamson et. al. 1988: 174). While socialist feminists and radical feminists sometimes shared common analyses and critique, the insistence on excluding men from participation in women's struggles often divided them. However, socialist feminists did advocate for an autonomous women's movement.

The socialist tendency within the women's movement, as one of the three main trends in feminism identified by socialist feminists, was just as politically varied. For instance, some socialist feminists organized in Trotskyist groups like the Revolutionary Marxist Group (RMG), the Fourth International, or the League for Socialist Action (LSA). Some joined Marxist-Leninist and/or Maoist parties like the Communist Party of Canada and Communist Party of Canada (Marxist-Leninist). 
Others organized as democratic socialists in the NDP and the Waffle faction. Still others organized in specifically socialist feminist organizations and collectives like the International Women's Day Committee, Toronto Socialist Feminist Action, and Cayenne but stayed clear of more structured parties and organizations. Finally, some had no political affiliations with these or other groups but still organized around various women's issues and saw their politics as socialist feminist. Also, in the turbulent 1970s, there could be considerable overlap between these different groups. To further complicate things, as I outlined in my introduction, the term socialist feminist can be interpreted broadly. All of these divisions reflected the larger political divisions within the left locally, nationally, and internationally. They often had their roots in the debates and struggles that predated the 1960s and 1970s, such as those discussed in Chapter 2.

Socialist feminists' strategy was to build a women's movement capable of mobilizing a broad constituency of women around issues affecting all of them (Stephen and Jones 1989; RGR 1991). Cross-class alliances were made, but socialist feminists set up their own groups, like the Toronto Socialist Feminist Action and the Vancouver Women's Caucus, so that they did not have to compromise on their analysis. Many socialist feminists organized in NAC based on the principles of coalition building, although others chose not to, and dismissed the organization as defaulting to liberal/bourgeois causes. Writing in defense of socialist feminists' participation in NAC, Jennifer Stephen and Miriam Jones (1989) argued, "although we [feminists] may politically disagree, we must defend each other's right to express differing points of view. Ours is not a homogeneous movement in terms of race, class, 
experience, education, language, sexuality, national origin, ability or perspective" (2).

Stephen and Jones maintained that socialist feminists were slowly moving NAC beyond the narrow focus of putting "pressure on elected officials" and being “accountable to women" to a "more participatory mass action approach" (1989: 2). They saw NAC's role in sponsoring “demonstrations and strike support pickets in recent years" as evidence of this (Stephen and Jones 1989: 2). Socialist feminists Judy Rebick, Marjorie Cohen, Laurel Ritchie, and Lynne Kaye were even elected to positions in NAC, demonstrating some confidence on the part of the broader women's movement in socialist feminist leadership. Socialist feminists played important roles in the movement, even if they never succeeded in becoming the dominant voice of the movement.

Socialist feminists had to carefully balance their involvement with the broader women's movement with their commitment to socialist ideals. $19^{\text {th }}$ and early $20^{\text {th }}$ century socialist organizers shunned cross-class alliances, ${ }^{44}$ but many prominent socialist feminists were later convinced of their importance. Notably, British socialist feminists, Juliet Mitchell and Sheila Rowbotham criticized the traditional left for oversimplifying the division between socialist and liberal women (Boxer 2007: 142). This perspective carried over to North America. Socialist feminists in Canada understood the challenges that cross-class alliances posed, but they were convinced

\footnotetext{
${ }^{44}$ Returning to the discussion in chapter 2, early organizers like Zetkin and others denounced crossclass alliances arguing, "there cannot be a unified struggle for the entire [female] sex...No, it must be a class struggle of all the exploited without differences of sex against all exploiters no matter what sex they belong to" (Boxer 2007: 132). Zetkin prescribed a "clean break [reinliche Scheidung]' between proletarian parties and other political movements. Despite continuing to advocate some feminist goals, she expressed 'extreme animosity' toward the idea of sisterhood, using derisory language such as 'stupid feminist dreams about harmony' to describe feminist politics and calling feminists 'middleheaded, wishy-washy, weak"' (Boxer 2007: 134).
} 
that the benefits outweighed the negatives (Stephen and Jones 1989). They believed that a united women's movement would be more powerful and capable of winning demands. In chapter 5, I discuss the challenges that socialist feminists faced when trying to hold on to their ideals and political perspectives while participating in broader coalitions.

Rebick (2005) argues, "socialist feminists played an important role" in the broader women's movement by "making sure that the interests of working-class women were part of the movement" (xii). It was often a struggle to have class inserted into feminist analysis or to link up the labour movement with the women's movement. Many women did not make the connection between the two, in the same way that men often did not consider women's issues to be a part of the trade union struggle or the struggle for socialism. In an interview with Stettner (2011), Peggy Morton argues,

As far as the socialist women were concerned, I think that we really had that consciousness that women have more reason to want to change the society, to build a new society, than anybody else and...we were convinced you couldn't really have the liberation of women or affirmation of women's rights within a capitalist system (210).

For Morton, the oppression women faced both as women and as workers solidified their commitment to revolutionary socialist change. Women workers had more to lose under capitalism and thus more to gain through socialist struggle. The Revolutionary Marxist Group published a pamphlet with a similar sentiment:

The intersection of women's consciousness and class consciousness is a powerful impetus to a political rupture with bourgeois ideology and 
reformism...A woman involved in a trade union struggle is immediately faced with the reality of her oppression as a woman in terms of the sexism of the organized labour movement, the sexual stratification of the labour force and the objective limitations placed upon her to participate in the struggle. In order to fight her special exploitation as a worker she is forced to struggle against her oppression as a woman (1975: n.p)

According to this view, women's unique position experiencing both capitalist exploitation and gender oppression made socialist women more revolutionary in their outlook.

\subsection{Socialist Feminists and Academia}

After World War II, the Canadian government significantly increased investment in post-secondary education, with new funding for universities, colleges, and CÉGEPS (Robbins et. al. 2008: 24). For the first time in Canada, working-class people entered into post-secondary education en masse, including many women (Jones 2014; Millar 2011). This changed academic and campus life in significant ways. With the entry of new strata of people into universities and colleges, coupled with the social movements of the time, pressure increased on administrators and educators to provide an education that more closely reflected the lives and experiences of the working-class, women, immigrants, and racialized people.

Some socialist feminists that I interviewed saw their academic work as an extension of their political work. Vogel (1989) argues, "in turning to theoretical work, participants in the women's liberation movement addressed practical issues arising out of their political experience" (6). The result of this turn was that major theoretical debates arose around the "root of women's oppression" and how its "cross-class and 
trans historical character" could be understood theoretically; around the relationship between "sex divisions of labour and women's oppression;" on how to understand the relationship between sex, race, and class; and how the struggle for women's liberation and socialism were connected (Vogel 1989: 7). Socialist feminists pushed the boundaries of what was considered by many leftists in Canada to be within the realm of Marxism.

Socialist feminists were part of a struggle that erupted in the 1960s and 1970s to establish Women's Studies in Canadian and Québec universities. Establishing Women's Studies involved a political struggle between feminists and university administrators, with each group often holding different ideas about what sort of education would be offered. University administrators wanted Women's Studies without the political militancy of the women's movement, while many feminist scholars saw the establishment of Feminist Studies programs and courses as a distinctly political act building on the energy of that movement (Robbins et. al. 2008). Robbins et. al (2008) explain,

When separate programs were set up, there were debates about whether to call them women's studies or feminist studies (later equity or gender studies)...In francophone Québec, the establishment of feminist studies, rather than women's studies, occurred quite specifically on the basis of militant and academic arguments...In the rest of Canada...administrations rejected the name 'feminist studies' as 'too political' (30).45

45 Robbins, Luxton, Eichler, and Descarriers's (2008) Minds of Our Own: Inventing Feminist Scholarship and Women's Studies in Canada and Québec, 1966-1976 offers an in-depth oral history of the struggle to establish feminist studies. 
By the end of the 1960s, some of the first Women's Studies courses were offered. While departmental and administrative politics determined, to a large extent, course content, who was hired, and whose voices were privileged, the establishment of Women's and Feminist Studies provided an unprecedented opportunity for women to study, teach, and write about gender issues in ways that were not previously available. In this period of increased politicization, in other programs such as Sociology,

it was assumed that one's research would be informed by and directed toward some political project...there was an assumed obligation that the 'radical' faculty would at least facilitate and make space for new kinds of both radical activism and theoretical ideas (Porter 1995: 424).

Many students were politicized on campuses, and many of these became involved in the women's movement by virtue of their experiences at universities (Palmer 2009). This, in turn, led to women's issues being taken up more broadly in academia and in campus life.

Socialist feminist academics were involved in the fight to have Women's Studies courses available to students. At the University of Toronto, Luxton and other feminist graduate students worked with a faculty member to set up courses. Luxton explains, "a number of us saw ourselves as Marxist-feminists at that point and were reading whatever material we could get and talking about it" to try "to figure out how you could teach a course on it." 46 Around the same time, Linda Kealey was involved “in the early stages of getting the Women's Studies program at Memorial

\footnotetext{
${ }^{46}$ Luxton, interview with author, July 19, 2018.
} 
University." ${ }^{77}$ She explains how many of the young women involved in this struggle to set up courses thought about their role as activists and academics:

Those of us in women's studies, at least in the early days, always thought of ourselves as the academic-wing of the women's movement. We had an obligation to be activists through our teaching and to try to change how gender issues were looked at...We weren't just doing this in the abstract but were doing it for social change...Having influence over students has been one of the things that...I would say does make a difference. The ability to teach women's studies or women's history does help shape the way people think and the way people act, hopefully. 48

Predictably, this activity was met with resistance from men who saw their positions in academia and broader society as jeopardized by women's ascent. Petersen recalled needing a guard around her class because there was at least one individual who sought to disrupt it. ${ }^{49}$

Even left-leaning departments were hesitant to welcome feminists and feminism into their ranks. Porter (1995) explains that, although programs like Sociology embraced radical students, "some eyebrows were raised when [radical projects] turned out to be feminist projects" (424). Women's issues were not viewed with the same seriousness, nor were they seen as particularly revolutionary in a time when revolution was the cause celebre. The academic output of socialist feminists in the period from the 1960s - 1980s was, however, complicated by the concurrent rise of post-modernism and post-structuralism, and its related break with Marxism and

\footnotetext{
${ }^{47}$ Kealey, interview with author, August 13, 2018.

${ }^{48}$ Kealey, interview with author, August 13, 2018.

${ }^{49}$ Petersen, interview with author, August 31, 2018.
} 
class politics (Porter 1995). This undoubtedly affected the work being done and its direction..$^{50}$ Marilyn Porter (1995) suggests "that the general trajectory of the 1980s is a loss of the kind of essential radicalism" that was "brought about by developments hostile to [radicalism] that we have encountered both in the universities and in the world outside" (428). Porter (1995) suggests three major barriers to putting forward a socialist or Marxist-oriented analysis: "the pressures of [women's studies] becoming an 'established' discipline in a time of recessions; the rise of conservatism and the New Right; and finally, the growing influence of 'postmodernist' theory" (427). She argues that, in this climate, socialist feminists began to "refer to 'policy work' or the impact on social policy or 'advocacy research"' which she argues "are all euphemisms for politically committed research" but questions "why did none of the authors feel able to write that as clearly as I know they can?" (Porter 1995: 428).

In many cases, women were forced to establish their own journals and presses to disseminate their work. Palmer (2006) credits the Women's Press for enlivening "historical materialism [in the early 1970s and mid-1980s] by infusing it with appreciations of women's experience and gender struggles" and "securing international reputations for its writers" (54). These writers included socialist feminists like Joan Sangster, Bonnie Fox, Mercedes Steedman, Meg Luxton, Linda Briskin and Lynda Yanz (Palmer 2006). The New Left Review also played an important

\footnotetext{
50 Barbara Epstein's work "Why Poststructuralism is a Dead End for Progressive Thought" discusses this in detail. Epstein (1995) argues that the poststructuralism embraced by feminists (and others) in academia undermines social analyses by turning away from politics and placing undue emphasis on difference over unity.
} 
role in disseminating socialist feminist work, such as Juliet Mitchell's "Women: The Longest Revolution" (1966) and Heather Jon Maroney's “Feminism at Work" (1983).

Luxton and Maroney (1987) document an experience of women's academic exclusion in Feminism and Political Economy: Women's Work, Women's Struggles. Their book "began as a critique of two conferences" held in the early 1980s. The first, held in Vancouver, discussed the "Left in the 1980s" but "failed to mention gender relations or women" despite women's increasing participation and organization in political movements. The second conference was held a year later to address this gap and to discuss "feminism and politics." While more than one hundred women showed up, only three men participated (Luxton and Maroney 1987: ix). These conferences, for Luxton and Maroney, revealed how the Left assessed the struggles of women. When I asked Luxton about this exclusion, she pointed out that such discrimination was commonplace, and that it still persists in academia:

They [leftist academic men] haven't dealt with feminism although they may gesture in that direction occasionally. They are better now at having the occasional woman publish stuff with them and they are on the lookout for leftwing women who aren't militant feminists and they basically ignore feminist interventions. They don't read our stuff and they don't engage in it...initially you could say it was because they were unfamiliar with it but after a while they know. They're choosing not to have anything to do with it...Most academic socialist feminists got fed up with trying to butt our heads with those guys and ignored them and went different directions. I mean, we had to read their stuff, but they didn't have to read our stuff...You got the growth of feminist scholarship and activism that is pretty independent of that. ${ }^{51}$

${ }^{51}$ Luxton, interview with author, July 19, 2018. 
Such were the inequalities that feminist scholars faced even amongst leftist academics. In spite of this discrimination, socialist feminists made major contributions to analyses of gender.

Not all socialist feminists were convinced of the merits of academia. Some socialist feminists regarded academia with skepticism due to its limited opportunities for leftist/feminist struggles. Perhaps the best example of this skepticism was the response of activists towards a socialist feminist conference held in 1984, organized by women from the academia-centred Committee on Socialist Studies. The conference aimed to bring together socialist feminists and other community activists under the slogan, “No socialism without women's liberation - No women's liberation without socialism" (Socialist Feminist Conference 1983: n.p). Responding to the call for a socialist feminist conference, activists from Vancouver, Montreal, and Halifax all replied with concern about the conference's focus on academic theorizing rather than to strategize how to push the women's movement forward. Activists from Vancouver put it plainly,

We want a strategy discussion. We're not against theory, but we know we don't want an academic conference of socialist feminists. We should be most interested in the kind of theory which informs our practice, which helps us figure out what to do (Socialist Feminist Conference 1983: n.p).

This concern reflected the seriousness with which socialist women activists approached their organizing. It was not enough to be writing, talking, and theorizing about the women's movement. These activities had to be grounded in the real challenges, victories, defeats, and problems coming out of the organizing being done. In examining the debates around the proposed 1983 conference, what is interesting 
is not only the concern raised by activists, but the approach of the conference organizers themselves. The organizers created a newsletter which they circulated for over a year to facilitate feedback from socialist feminists across the country on what they would like to see discussed (Socialist Feminist Conference 1983). This approach differs considerably from that of typical academic conferences, whereby organizers decide on a topic, issue a call for papers, and then select the participants based on their expertise and prestige. The organizers of the early 1980s socialist feminist conference, on the other hand, demonstrated a real effort to address the challenges women organizers faced, by going to them directly and asking what kind of discussions would aid their work (Socialist Feminist Conference 1983). The conference was not aimed only towards academics but also towards activists and community organizers were invited to speak. In this regard, while there was considerable skepticism of academia among activists, the conference organizing suggests that socialist feminist academics were "doing academia" in a way that aligned more closely with their feminist values and the struggle for women's liberation. This suggests that socialist feminists in academia understood, as Luxton (2015) later pointed out, that "there is no necessary link between theory and practice" (164) and that there can exist a real disconnect between what is written, discussed, and considered important in academia, and what are the specific experiences of activists.

Peggy Morton (2005) was also critical of academia, arguing that the university, as an institution, was never the place to engage students for transformative change. Instead, Morton argued, the disconnect between academia and activism meant that 
the theory discussed in the former was always abstracted from the struggles of the latter:

I had tried to read some Lenin and Marx in university. We wanted to deal with burning questions facing society. But it was just all this language being used to bludgeon you. It no longer had any meaning in terms of analyzing what was going on in society and solving the problems that people are facing. What is theory if it can't guide you? It just becomes this dead thing that you hit people over the head with (7).

While this tension between academia and activism existed, it was not a cut and dry division. The universities were a hotbed of radicalism in the 1960s - 1970s, out of which many socialist feminist activists came. Setting up Women's Studies departments and courses was also political act, and exposed young people to a feminist and socialist feminist perspective. It was in the 1980s - 1990s that the divide between socialist feminists in academia, and activism became more pronounced, after the dissolution of much of the remaining radical left.

\section{Conclusion}

This chapter touched on important divisions in the Women's Movement and the Left. In summary, socialist feminists' vision for political change encompassed the complete overthrow of existing political and economic relations. This differed from the radical feminist position which saw women's emancipation as rooted in the overthrow of patriarchy and the liberal feminist view which saw women's lack of incorporation in the existing society as the problem. Divisions were also present among socialist feminists who ascribed to the view that capitalism was their main enemy. The major divisions were grounded in what organization and strategy 
socialist feminists felt would lead to the revolutionary change they saw as essential to women's emancipation, often mirroring the Old-New Left divide. Another divide emerged between socialist feminists on whether academia was a fruitful endeavour or distraction from "real," on-the-ground organizing. Neither the tension between party politics and autonomous practice, nor that between academia and activism were resolved within socialist feminism. This is unsurprising, as the former particularly is still subject of contention on today's left. ${ }^{52}$ However, these political differences affected how socialist feminist political work played out in practice, which will be explored in the next chapter.

\footnotetext{
${ }^{52}$ For instance, recent debates within the U.S. organization Democratic Socialists of America have centered most significantly on divisions over "horizontalism" (Cozzarelli 2019) and whether the organization should be led by decentralized local bodies or an elected executive (Fong and Sernatinger 2019). Horizontalism is roughly analogous in this case to politics that emphasize prefiguration, reject hierarchies, prefer consensus, and favour loose organizational structures.
} 


\section{Chapter 4: The Political Activism of Socialist Feminists}

In this chapter, I explore the different struggles that socialist feminists were involved in order to explore their approaches to coalition building, leadership, decision making, and attempts to merge a socialist and feminist politic. The movements examined here include reproductive rights, International Women's Day, anti-racism, labour issues, universal daycare, and the Wages for Housework campaign. This chapter draws heavily on the Rise Up! Feminist Archive and interviews with activists who were involved in these struggles. I ask how socialist feminists were able to build coalitions with the broader women's movement and what successes they had. How did they see women's struggles fitting in with socialist struggles? What socialist organizations did they work with and what were their positions on women? How did men in the labour movement and socialist movement treat women organizers? I also address how socialist feminists saw capitalism structuring the oppression of women.

\subsection{Abortion and Reproductive Health}

Socialist feminists participated and were leaders in the movement for abortion access in Canada. Many put forward the position that reproductive rights could only be secured through socialism. In Larkin's words, “[socialist feminists were arguing] if you are really going to support abortion, you have to be a socialist feminist. It's bullshit but that's what we were arguing" (as quoted by Rebick 2005: 42). While exaggerated, the position contains a kernel of truth. Access to abortion, and reproductive health generally were and are linked to material economic issues such as employment, income security and financial independence, as well as access to 
healthcare and pharmacare; women's material well-being and economic security influences their ability to make meaningful reproductive choices. Furthermore, these issues have implications for the quality of life for mother and child. In the 1970s, big wins for maternity leave had yet to occur and daycare was inaccessible to many. Today, while safe abortion access has been achieved for arguably most women in Canada, for women to have real choices about whether to and how to raise children, larger societal issues must be addressed.

This understanding spurred significant discussion among socialist feminists. In 1984, Kathleen McDonnell wrote Not an Easy Choice: A Feminist Re-Examines Abortion, which was positively reviewed in an issue of Cayenne for its honesty about the "systematic lack of support for women's dignity and autonomy...in particular over reproductive rights." McDonnell wrote about the "irony of having choice without money" (Lorenzo 1985: 44). Lorenzo (1985) echoed, "clearly, before we can talk about free choice, we must attain economic independence for women, so that working-class and poor women, for example, will not be forced to abort children they would rather have but cannot afford" (44). Similarly, Melody Kilian (1962), of the Louis Riel University Co-op, argued that capitalist society was the biggest obstacle to motherhood. Capitalism, Kilian argued, isolated mothers from society and political activity. The only viable solutions presented by the women's movement was increased access to birth control and abortion. Kilian (1962) felt like the movement had to do more to make bearing and loving children easier. It should focus on "not only how to prevent unwanted children but also how to create the possibility of wanted children for ourselves. How can we have babies in a society that makes babies 
burdens to everyone, particularly to women, and at the same time not lose our ability to work effectively to destroy this inhuman system?" (2).

Abortion was one of the first issues around which women organized on a national level in Canada (Rebick 2005: 35). ${ }^{33}$ The initiative began after Betsy Wood ${ }^{54}$ approached both the Liberal and NDP parties about her concerns for women's safety and their right to choose, and her concerns were laughed off by both parties (CBC 2018). Rather than admit defeat, Wood's response was to organize a group of women from various organizations to discuss the issue in Vancouver. At the meeting, it was decided that a Caravan would travel across the country meeting women and discussing the issues of reproductive health and access to abortion (CBC 2018). In 1970, the Caravan left for Ottawa. Prominent socialist feminists and communists became involved in the caravan, including Meg Luxton, Jackie Larkin, and Peggy Morton. In an interview with Rebick (2005), Larkin describes being released from her duties as the national organizer of the Waffle to participate in the Caravan. The Caravan, she says, was composed of "socialists, students, women and anti-war activists" (as quoted by Rebick 2005: 39).

The Caravan stopped in various towns along the way to Ottawa. The women held meetings where abortion access was discussed using "guerrilla theatre to highlight the issue of uneven access to legal abortion services" (Bronskill 2018). The Caravan allowed activists to touch base with some smaller communities that were

\footnotetext{
53 The first, to my knowledge, is the Women's Labour Leagues.

${ }^{54}$ Betsy Wood did not identify as a socialist feminist. In an interview with Frances Wasserlein (1980), Wood rejected "being identified as belonging to a particular class" but said that "she comes from a 'working family'" (46).
} 
often untouched by the politics of city centres. When the women were met by CBC radio, they told the media that they would "declare war on the government" if they refused to meet with them once they were in Ottawa (CBC 2018). The Caravan got to Ottawa on Mother's Day weekend, 1970. On Saturday, "a thousand women rallied on the Hill" and on Monday, "they shut down Parliament" (CBC 2018). Women disrupted the House of Commons by entering and chaining themselves to gallery seats and chanting slogans in support of abortion access - "Women Are Dying! Abortion Laws Kill!" (CBC 2018). In an interview with Stettner (2011), Peggy Morton recalls the action:

It was so funny, if you can just imagine these 30 to 40 odd young women with the typical dress of the time, putting on make-up for the first time in years we'd all sworn off make-up - doing our hair in these nice little buns, and putting on high heels and nylons, and all these clothes that we hadn't worn in years, making ourselves look like such nice little things, then getting into the gallery and then chaining ourselves (279).

They raised no suspicion getting into Parliament because of their dress. No one was arrested, because the government rationalized that the Caravan had received so much support travelling across Canada that it would look bad to begin imprisoning these women (CBC 2018). Some months later, Pierre Trudeau called a meeting with some of the women of the Caravan. In the meeting, the women argued that access to abortion was different depending on the class you occupied. It was only the poor and working-class who didn't have access to abortion, when rich women could easily attain one (CBC 2018). Trudeau's response was "so what?" (CBC 2018), highlighting the divide between liberal, working-class, and socialist feminists. 
The Abortion Caravan was a significant moment in women's organizing history in Canada. The movement was strengthened by the presence of socialist feminists who were not afraid to speak about how women's oppression was structured by capitalism. While the Caravan did not achieve access to abortion, it did garner attention from the media and politicians which helped the cause. Many of the women who got their political start in the Caravan ended up working on other prochoice projects like the Ontario Coalition for Abortion Clinics (OCAC) and went on to have careers as militants.

In 1982, OCAC was formed "to challenge a system that was denying abortion" to women (Rise Up! Feminist Archive 2018b: n.p). Not all the women who organized in OCAC were socialist feminists, but many were. ${ }^{55}$ Carolyn Egan explained some of the difficulties women were facing:

I worked in a birth control centre and I was close with women who were working in the Immigrant Women's Health Centre and another centre called the Hassle Free Clinic. We were in a situation where all of us, and other centres across the city, were having a tremendous challenge referring women for abortions. It was extremely difficult at the time...For working-class women, poor women, for women of colour, women on reserves in the North, or brown women, it was extremely difficult. We were struggling all the time to try to get referrals for women...a lot of gynecologists were asking for extra money and women couldn't afford it...We started organizing and there was a real resonance...because it was something that really affected women in a very concrete way and the reality of women's lives if they became pregnant, the

\footnotetext{
${ }^{55}$ Egan, interview with author, October 1, 2018.
} 
options were very limited. So, we started the Ontario Coalition for Abortion Clinics. ${ }^{56}$

One of the first things OCAC did was establish "an illegal abortion clinic in Toronto" (OCAC 2018), with the help of Dr. Henry Morgentaler and two other physicians. ${ }^{57}$ In 1983, shortly after having been set up, the clinic was raided by police and doctors were arrested (OCAC). The raid was a setback, but organizers "fought to keep it open so that abortion could be accessible to all women" (OCAC 2018). More than 4,000 protesters gathered after the raid to demand that the clinic be reopened, and that abortion be made accessible to all women. While OCAC focused on reproductive rights, they also joined struggles for "a number of rights like the right to childcare, pay equity, and against racial and sexual harassment, freedom from forced or coerced sterilization which women with disabilities, black women, women of colour, and Indigenous women were subjected to" and "the need for decent jobs." 58 Women from the coalition understood that "all those things were necessary if women were truly to have choices in our lives." 59

OCAC received no support from any of the mainstream political parties but understood that they would need to build broad support if they were going to win. Rebick joined the NDP to help gain support within the party: "nobody else [from OCAC] wanted to get involved...so I did it because I had this Trotskyist idea that you can work inside and outside." 60 Bob Rae, the ONDP leader, "wouldn't support it. He

\footnotetext{
56 Egan, interview with author, October 1, 2018.

57 Egan, interview with author, October 1, 2018.

${ }^{58}$ Egan, interview with author, October 1, 2018.

${ }^{59}$ Egan, interview with author, October 1, 2018.

${ }^{60}$ Rebick, interview with researcher, August 6, 2018.
} 
said he was pro-choice but that we needed to support 'the rule of law.'”1 61 The ensuing fight for reproductive rights within the party was highly divisive but through the efforts of Rebick and others support within the NDP was won:

We had a huge fight with the leadership office for supporting the Morgentaler clinic...[Rae's] office tried to stack the election for the Women's Committee to stop us from supporting the clinic. The labour women were besides themselves and fought back. His staff was calling union leaders to try to get them to stop labour women from supporting Mary Ralls who was the prochoice leader of the Women's Committee. It was gross...but we won. We defeated them...They actually bused women from Bob Rae's riding to the meeting. We beat them not only at the Women's Committee, but we beat them at the next convention too. ${ }^{62}$

While winning the support of the NDP was not the deciding factor in the final victory for legalized abortion, it was one step in garnering more attention and more support.

Socialists, for the most part, strongly endorsed the legalization of abortion, arguing, like the LSA did, that women "must have complete control over [their] bodies...[and] any and all restrictions on the right of women to determine whether or not to bear a child should be removed" (LSA 1968: 5). They also argued that it was the government's responsibility to "initiate [and finance] a widespread educational campaign on birth control and establish community birth control centres for the dissemination and distribution of birth control information and devices" (LSA 1968: 5). For socialist feminists, "the struggle for abortion" was "fundamentally a class issue" (International Socialist 1987: 7). It was "working-class women who...suffered

\footnotetext{
${ }^{61}$ Rebick, interview with researcher, August 6, 2018.

${ }^{62}$ Rebick, interview with researcher, August 6, 2018.
} 
most from the limited access to abortion rights in Canada" (International Socialist 1987: 7). Also, it was understood that some women did not have the option to have children because of the "social and economic conditions" which forced them into wage labour and exploitation. Increasing "prices, lagging wages, inadequate day care facilities and the general climate of economic insecurity" forced many women "not to have the children they want[ed]" (1979).

While socialist feminists agreed that access to abortion was a class issue, the founding of OCAC led to debate on the correct strategy for its establishment. After Rebel Girls' Rag published an invitation from the International Socialists (IS) to a discussion on the "Way Forward for Abortion," debate erupted between OCAC and IS on whether opening clinics was appropriate. The criticism from IS was presented by Nancy Nicol (1986), ${ }^{63}$ who argued that socialists should support abortion being provided in hospitals, not clinics, and that this could be achieved by working with unionized health care and social service workers. OCAC, she maintained, relied too heavily on a legal strategy for obtaining abortion access by challenging the existing legal framework (OCAC 1987). Egan, a health care worker at the time, responded to this criticism by describing how health care workers had been fighting for over 9 years "against decreasing hospital access and cutbacks" and that health care workers were changing their approach based on these failures (Gellatly 1988: 6). OCAC, she argued, was the way forward (Gellatly 1988: 6). Gellatly (1988), reporting on this debate and supporting OCAC's position further argued,

\footnotetext{
${ }^{63}$ Nancy Nicol was the producer and director of a video series called "The Struggle for Choice."
} 
while we knew doctors would be charged, the campaign did not rest on the legal parameters established by court proceedings. Like striking workers who defy back-to-work legislation, we can mobilize around state attacks. The clinic strategy was a tool, a catalyst for building a broad-based movement with the capacity to organize (6).

Ultimately, it was the legal case against Morgentaler which resulted in new legislation. In 1988, the Supreme Court of Canada ruled that the existing abortion laws were unconstitutional in R. v. Morgentaler. However, this would have been impossible without the broad-based support that was garnered by abortion activists from all perspectives. While this was a major victory for activists and women, the struggle continues today to guarantee safe and legal abortion in many provinces.

The issue of abortion was not without its tensions and complications. While many fought for access to abortion, forced sterilization was a reality that immigrants, disabled, and Indigenous women faced in Canada. Sometimes women were punished for abortion with forced sterilization. Beth Palmer (2012b) explains, "even after high profile cases of forced sterilization in Canada, like that of Leilani Muir in Saskatchewan in 1959, the Canadian reproductive rights movement lacked a framework to include these contradictions in their struggles" (12). The practice of forced sterilization was in place in Canada since the 1930s and can be understood as one of many policies employed to undermine Aboriginal women, to separate Aboriginal peoples from their lands and resources, and to reduce the numbers of those to whom the federal government has obligations...the effects of the sterilization of Aboriginal women, whether intended or not, are in line with past Indian policy and serve the political and economic interests of Canada (Stote 2012: n.p). 
While forced sterilization can be understood as a class issue affecting the most poor and oppressed women, its exclusion from issues on the agenda for the pro-choice movement was an oversight by socialist feminists organizing for abortion access. While they were aware of the practice, it was given less attention and analysis than warranted. In Canada and the US there was also debate within social movements about who the fight for abortion was for and what it would mean for poor, racialized, and Indigenous women. In particular, Black and Puerto Rican nationalists reminded "white feminists that for many people of colour, reproductive control was closely associated with genocide" (Palmer 2012b: 12). In 1987, the International Women's Day organizers circulated a pamphlet stating that choice was "an illusion for most Asian, Native, Black, South Asian and other women of colour and immigrant women" who, on top of being denied access to abortion, were "forced or coerced" into sterilization and being used as test subjects for Depo Provera.

\subsection{International Women's Day and the IWD Committee}

As I noted in Chapter 2, the first International Women's Day in Canada was organized by the Women's Labour Leagues after their revival by the Communist Party of Canada. One of the lasting successes of socialist feminists was the restoration of International Women's Day in Toronto decades later. In 1975, Varda Burstyn, a socialist feminist coming from the Revolutionary Marxist Group, took the initiative to organize a "meeting of women from a range of organizations to talk about the perception in the newspapers that the women's movement was dead" (Egan 2017: n.p). Burstyn had a desire to bring together various forces in the women's movement 
to cohere a socialist feminist current. Prior to IWD, these forces had been isolated in their own distinct struggles. In an interview, Burstyn recalled that while considerable activity was taking place, the movement needed a unifying force. She determined that the organizing of a large march of the forces comprising the socialist feminist current could bring participants closer organizationally and politically ${ }^{64}$ At the time, Burstyn was a part of the new Revolutionary Workers' Party which was a forced merger of the League for Socialist Action, RMG, and Groupe Marxiste Révolutionaire (GMR) initiated by Fourth International. The merger caused a lot of infighting between members who had different opinions about what the focus of their political work should be. Part of Burstyn's motivation for organizing women was to demonstrate to the socialist left, in particular former members of the LSA, the importance of a vibrant and organized women's movement. Part of the RWP leadership was advocating a "turn to the working class" that Burstyn saw to mean abandoning work among the women's movement, the LGBTQ movement and elsewhere, and moving into industrial work. Opposing this turn, Burstyn set out to show the organization's leadership the importance of work in the women's movement through a show of force. ${ }^{65}$

At the first meeting it was decided that IWD would be organized again after a lapse of many years. However, the way that it would be organized was a matter of great contention, reflecting a split between radical and socialist feminist perspectives. The debate that ensued centred on whether men would be allowed to participate in the march. Women from the radical feminist group Women Against Violence Against

\footnotetext{
${ }^{64}$ Burstyn, interview with the author, January 10, 2019.

${ }^{65}$ Burstyn, interview with the author, January 10, 2019.
} 
Women (WAVAW) believed that men should not be allowed to march alongside women. Socialist feminists, on the other hand, thought that the march would garner more support and be more impactful if it included male allies. In an interview with Rebick (2005), Egan explains the split from the perspective of socialist feminists,

As the planning began, a very real political difference began to emerge. There were women who defined themselves as radical feminists and those of us who defined ourselves as socialist feminists, and no doubt many in between. To my mind, the question was about how to organize, how to be inclusive and build a broad mass movement, but it became focused on whether or not men should be allowed to participate in the march (117).

For Egan and others, who understood the problem of women's oppression not primarily as male domination, but rather as capitalist domination, a strong movement against women's oppression would require support from men - most of all, from working-class men who perhaps had more in common with working-class women than radical feminists acknowledged. From the perspective of the radical feminists, Susan Cole argues,

We wanted the demo for women only...We felt that there would be nothing more powerful for women to see than a large group of angry women asserting themselves. Politically speaking, we felt that even though the numbers might be smaller, the impact would be stronger. We were trying to articulate a different aesthetic...Socialist feminists had been political longer, and their politics came from a different place. The movement against violence against women came from women who had had that experience...The radical feminist view was that everything springs from gender difference. That was the politics I was working on (as quoted by Rebick 2005: n.p). 
Coming from the perspective of viewing patriarchy as the primary source of women's oppression, it made sense for radical feminists to attempt to exclude men from the march. However, with the two perspectives diametrically opposed, no agreement could be reached. The group split and formed two separate marches - one that included men and one women-only march. The latter, as expected, was smaller, "maybe two hundred women...who functioned within the structure of the women's movement" whereas the following day "a broad cross-section of women who believed they were struggling for women's equality" came out, approximately 2000 (Egan 2017: n.p). The first IWD had a range of speakers from various communities. Lorna Hall spoke about the deportation of Jamaican mothers. Deirdre Gallagher...spoke for Organized Working Women on the issues of women and a whole range of other feminist issues [were discussed]...We had a large, boisterous, and militant crowd...[who came] out to support the women's movement and to march in the streets of Toronto saying the women's movement is not dead...To our minds it was a hugely important event. ${ }^{66}$

For socialist feminists, this was a victory, and further, a demonstration that women were more likely to take part in marches and movements that encouraged their male friends, family members, and allies to join. For socialist feminists, the march was proof that alliances could be made with men and that a broader, more inclusive movement was the winning strategy.

The International Women's Day Committee (IWDC) was formed in 1979 from the split between radical and socialist feminists who met to discuss IWD. The IWDC

\footnotetext{
${ }^{66}$ Egan, interview with author, October 1, 2018.
} 
was an explicitly and unapologetically socialist feminist organization. The organization argued that socialist transformation had to be a part of the women's movement if it was to secure real gains for women: "we believe that the oppression of women touches every aspect of our lives and that the liberation of women will require fundamental changes in the structure of society" (IWDC 1982b). Gottlieb recalled IWDC as being an important place "of conversation and discussion" and for "hashing out positions in relation to being socialist feminists." 67 For her, and others, International Women's Day,

wasn't just a once a year march and protest. It was actually a way to focus the demands and campaigns of the feminist movement and it was a way to build coalitions with various components that were a part of the feminist movement at that time. So, bringing in the labour movement, bringing in women who were working around issues of race and racism, and the situation of domestic workers and immigrant women...bringing in the issues of Indigenous women in terms of their fight against the Indian Act and the ways in which they were discriminated against and lost status when they married out of their particular group...Ways in which lesbians and their particular fight was taken up in the feminist movement. Legal issues around daycare, childcare, abortion, and reproductive freedom. All these issues were brought into the coalition and all of the groups that were working on different issues in the movement were brought to the coalition and each year the demands and the way in which the march was organized...were discussed and hashed out. ${ }^{68}$

IWDC took various forms throughout the years (1978-1987). The organization strove to meet, at minimum, once per month throughout the year (Rebick 2005: 119). Some

${ }^{67}$ Gottlieb, interview with author, December 6, 2018.

${ }^{68}$ Amy Gottlieb, interview with author, December 6, 2018. 
years it met more, some years it met less. While it strove for consensus amongst its members, decision-making on policy and the overall direction of the organization was carried out through debate and then a vote (Rebick 2005: 119). All the work of the organization was done on a volunteer basis, with no remuneration. Over the years, IWDC committees worked on various issues and reported back to the group as a whole. At one point, there was a Coordinating Committee, Trade Union Committee, Education Committee, Newsletter Committee, Women's Movement Committee and New Members Committee (IWDC 1982). By dividing work up into committees, IWDC members actively promoted the organization and kept close links with the larger women's movement and trade union movement. One of the forms through which IWDC communicates with its members and with the broader Left was its quarterly newsletter, the International Women's Day Newsletter (1979-1986). The newsletter began as a one-page summary of events in the Toronto area, but later expanded to discuss various issues, events, and political opinions, and often responded to criticisms aimed at socialist feminists and their organizations. The newsletter connected socialist feminists active on various campaigns but who were not always in the same organizations. ${ }^{69}$ In this way, the newsletter played an important role in connecting activists in Toronto and sometimes in other parts of Canada.

IWDC's adherence to socialist feminism brought them into heated debates with other feminists and leftists. These debates help to highlight important aspects of

\footnotetext{
${ }^{69}$ Some groups that supported IWD included Organized Working Women, Women's Resource Centre, Equal Partners Committee (Local 524, United Electrical Workers of Canada), and Women Against Sexual Assault (IWDC Correspondence 1983).
} 
socialist feminists' particular political perspectives. In 1983, Broadside magazine ${ }^{70}$ criticized IWDC and the March $8^{\text {th }}$ Coalition for having "exclusionary politics" that prioritized socialism over feminism. The March $8^{\text {th }}$ Coalition had been set up by IWDC specifically to ensure that feminists of all political backgrounds could meet to organize the IWD march and events. According to Steinecker (1985), the group was a "a loose coalition of pro-feminist groups and individuals" (8). But liberal feminists like Lois Lowenberger argued that socialist feminists held too much control. ${ }^{71}$ It is likely that IWDC did hold sway over how some things were organized, given their position as facilitators of the coalition. But, the structure of the March $8^{\text {th }}$ Coalition did make it possible for women of different political backgrounds to have their concerns addressed. IWDC was, in this vein, regularly attacked for adhering to socialist politics, but the group never backtracked on its positions. IWDC (1983d) responded without apology for its politics,

Yes, IWDC is a socialist feminist organization; we have described ourselves as such since $1979 .$. We take issue with the assertion that socialist feminism as practiced by IWDC is exclusionary. While it is true that we ask women joining IWDC (the group not the Coalition) to agree with a general socialist feminist basis of unity, within which there is room for diversity of socialist and feminist opinion, we regularly initiate and/or participate in coalitions of feminist and progressive groups. In fact, mass action and coalition building constitute the cornerstone of our politics and practice (4).

\footnotetext{
${ }^{70}$ Broadside was "feminist newspaper that published for 10 years between 1979 and 1989" (Broadside 2012: n.p). Broadside wrote that "At a time when there were feminists galore - liberal feminists, lesbian feminists, equality feminists, socialist feminists, cultural feminists, and many more - you couldn't really put a label on" the publication, but the majority of the women in the Broadside collective "called themselves radical feminists" (Broadside 2012: n.p). Their magazine often reflected a radical and liberal perspective on the women's movement.

${ }^{71}$ Lowenberger was a Toronto lawyer involved in feminist legal issues. More about her specific arguments in the next section.
} 
Socialist feminists agreed that operating on "the principle that mass actions" was their "most effective instruments of change" (IWDC 1982b). For example, Maureen Fitzgerald (1979), an IWDC member, argued that in marching together on IWD with a diverse group of women and feminists,

We are saying that all these struggles are one. They belong to all of us. We cannot say, 'well, that's her issue because that's her union or because that's where she works' or 'that's her issue because she's a working mother or that's her issue because she's a lesbian...these issues are tied together and our strength is in fighting them together and we are (as quoted by Briskin and Weir 1992).

While socialist feminists believed that working together with other feminists could bring about progressive change, they also saw the significance of maintaining their own specifically socialist feminist and socialist groups. This allowed them to concentrate on their own socialist political analysis while taking part in and bringing said analysis to the larger movement. In addition, socialist feminists in IWDC sought to build broader coalitions with women organizing against racism and colonialism. In part, this goal was a recognition of some of socialist feminists' own weaknesses when it came to these issues, which will be touched on in the following chapter. In Chapter 5, I will discuss how this commitment to working with as broad a base of feminists as possible was, at times, taken too seriously, to the detriment of socialist feminists' own politics. This criticism was made at times by women who left IWDC out of frustration with organizing based on unity with more politically reactionary forces.

Despite the criticism the group sometimes faced, IWDC remained the coordinator for the March 8th Coalition each year until 1985. Stienecker (1985) 
argues, "the enormity of these yearly responsibilities...hindered IWDC's ability to develop and implement its own strategies" for the women's movement (8). These responsibilities were often time-consuming; the planning of IWD was a yearlong process. After handing over these responsibilities in 1985, IWDC began to focus more closely on the development of the organization (Stienecker 1985: 8). The group renamed itself as Toronto Socialist Feminist Action (TSFA) (1987-1992) and its newsletter became Rebel Girls' Rag (RGR). TSFA continued to operate "on the principle that mass action" was their "most effective instrument of change" (RGR 1987a: 2) and worked on many of the same issues and campaigns as IWDC. Stephen (1989) wrote about TSFA, "our limited energies continue to go toward extraparliamentary activities which, we believe are more consistent with the principles of mass action and coalition politics. We have an important function as socialist feminists in helping to build the popular movements in which we are active and put forward a mass action strategy whether it is in the struggle for reproductive rights, anti-imperialist solidarity, trade unions, or the women's movement" (3). Women in TFSA continued to participate in International Women's Day events and marches, and worked with Ontario Working Women, the Ontario Coalition for Abortion Clinics, and the Revolutionary Workers' League. TFSA also focused on winning demands at NAC, writing:

Our interventions and participation in the National Action Committee on the Status of Women provide a concrete example of TFSA's strategic decision to work within a mainstream organization around a limited agenda...While NAC is a liberal feminist organization, it remains an important site for connecting with other women's organizations, for doing educative work, putting forward 
a socialist feminist analysis and strategy, and building a bi-national base of support for the decriminalizations of prostitution and against the implementation of a new abortion law (Stephen 1989: 3).

The group dissolved in 1992 because of internal issues related to capacity building and the inability to solve issues of organization (discussed in detail in the following chapter) and external issues related to the decline in the Left and socialist movements generally.

\subsection{Anti-Imperialism and Anti-War}

One feature of the socialist feminist activism of the 1970s is the strong antiimperialist stances that these activists took. In the 1960s, 1970s, and 1980s, support for those targeted by the U.S. was widespread and embraced by the various sections of the movement. Nationalist movements inside China, Korea, Nicaragua, Guatemala, Chile, Cuba, El Salvador, Vietnam, Palestine, Zimbabwe, and South Africa were supported based on their struggles for independence, against U.S. interventions, and for socialism. Egan recounts,

In Toronto at the time, there was so much immigration from Latin America, of women who had the experience of the dictatorship in Chile, wars in El Salvador and Nicaragua, and those were the people we were working with and rubbing shoulders with. So, that sense of how women suffered through those but also, just what war, imperialism, and colonialism does. It's part of the system that we live under. I think that had a huge influence on us. ${ }^{72}$

Voice of Women (VOW) became a prominent anti-war organization, with its beginnings in the movement for nuclear disarmament in the 1960s (Chenier 2006).

\footnotetext{
72 Egan, interview with author, October 1, 2018.
} 
VOW was a non-partisan group that took an anti-nuclear position and even helped organize meetings with "women from the Soviet Union and other socialist countries" to promote peace (Grady 2018). During the same decade, the Student Union for Peace Action activists, including many socialist feminists, helped organize demonstrations, rallies, and meetings against war. These groups formed committees and united fronts to mobilize "Vietnam protests across the country" (Palmer 2012a: 273). Socialist feminists played their own role, supporting these struggles and working together with others to showcase how women were often the primary victims of war and imperialism. In particular, many helped in VOW's effort to organize an Indochinese Conference $^{73}$ which brought together North Vietnamese, South Vietnamese, and Laotian women to speak about the war in Vietnam:

That conference was organized by feminists...It's an interesting moment to think about. Women saw that as very important that they were reaching out across those differences but saw this as a struggle that we had to make together against imperialism and against our government's complicity in the Vietnam War. ${ }^{74}$

There was a lot involved in [the anti-war and anti-imperialist struggles] in terms of thinking about the Vietnam War and what was going on there. I was one of the representatives for the Women's Liberation Movement at the [Indochinese] Conference, there was one in Vancouver and Toronto, which invited North Vietnamese, South Vietnamese and Laotian women to come and speak to Canadians and American women...We listened to them talk about

\footnotetext{
${ }^{73}$ Socialist feminists, Trotskyists, and Maoists were involved in the organization of the Indochinese conference. For their part, the CPC refused to be involved because the conference organizing was in the hands of their rivals. One member noted that the Indochinese women were, therefore, "playing with the enemies of the Communist Party" (as cited by Sethna and Hewitt 2018: 119).

${ }^{74}$ Gottlieb, interview with author, December 6, 2018.
} 
chemical warfare, the use of exfoliants in Vietnam, birth defects, how women

and children were often the victims of war and talking about how many orphans were left in South Vietnam. ${ }^{75}$

There were six speakers at the conference: "Vo Thi The, a professor of literature; Nguyen Thi Xiem, a gynecologist and obstetrician; Dinh Thi Huong, a housewife; and teachers Phan Minh Hien, Khampheng Boupha, and Khemphet Pholsena" (Sethna and Hewitt 2018: 115). The conference and its speakers were monitored closely by the RCMP because, while Canada stayed out of the Vietnam War, "its Cold War political interests remained aligned with those of the United States" (Sethna and Hewitt 2018: 106). Furthermore, the RCMP had long viewed VOW, incorrectly, as a communist led organization (Sethna and Hewitt 2018). So, when North Vietnamese, South Vietnamese, and Laotian women were invited to speak, the RCMP viewed the event as an international communist-led threat to Canadian democracy (Sethna and Hewitt 2018). ${ }^{76}$

75 Kealey, interview with author, August 13, 2018.

76 The RCMP surveilled and directly interfered with movements throughout the 1960s, and these efforts increased in the 1970s. In the 1970s, the RCMP began to argue that "the virus [radicalism] that infected campuses in the latter half of the 1960s was now in the process of spreading in the wider society" (Hewitt 2002: 173). Of special concern to the state was the solidarity being forged between different national and international struggles. In Canada, the RCMP worked in partnership with US state agencies in a counterinsurgency program known as COINTELPRO (the Counter Intelligence Program) to destroy radical movements (Harris 2007). Working together, the Federal Bureau of Investigation (FBI) and its Canadian counterpart, the RCMP, were in some cases successful in infiltrating, undermining, and destroying the most radical elements of the Indigenous, Black, socialist and communist movements (Harris 2007).

The women's movement was likewise targeted by the RCMP. Christabelle Sethna and Steve Hewitt's (2018) book Just Watch Us, documents the extent of the surveillance and infiltration of the women's movement. Sethna and Hewitt note that this government and RCMP fear of the movement's infiltration by communists and socialists was a main reason given for this targeting. The RCMP, for example, diligently followed the Abortion Caravan, reporting on the activities of participants. While the Royal Commission of Inquiry into Certain Activities of the RCMP (McDonald Commission) report of 1981 shed light on many instances of RCMP subversion of social movements, much of the Commission's findings remained secret and much of the report remained heavily censored. As well, files on Operation CHECKMATE, a wide-ranging program of illegal activities directed against left-wing groups from 1972-1974, were destroyed in the mid-1970s by a decision of the RCMP Special 
Socialist feminists frequently worked with other coalitions to promote peace and anti-imperialism during the 1980s. Their goal was to link the women's movement with anti-imperialist struggles, and thereby make the connection between national oppression, war, and women's oppression. In October 1982, IWDC worked with the Canadian Action for Nicaragua (CAN) and Women's Action for Peace to co-sponsor a public workshop titled, "Why Are We Working Together: Political Activism and Coalition Politics in the 1980s" (IWDC 1982b: 3). The event was held to build support for a "March Against War in Central America" taking place later that month, but also to argue for the necessity of coalition-building in response to war. At the event, Maria Teresa Larrain, a member of the solidarity group Women Working with Immigrant Women, "emphasized the need for the different groups to freely criticize one another so that we can work together from a basis of common commitment and not out of phoney respect" (Wright 1982: 3). It was on this basis that socialist feminists worked with other groups. Some of the anti-imperialist events that socialist feminists attended, organized, or sponsored by socialist feminists included: Anti-nuclear demonstration in Toronto (April 1980), War, Women, and Liberation: Nicaragua, El Salvador and Guatemala (June 1982), Stop the Cruise Missile: Ottawa Demonstration

Operations Group (Whitaker, Kealey, and Parnaby 2012: 337). Hewitt (2002) further notes on the destruction of RCMP records of their subversive activities:

The [RCMP] Security Service, with the federal government's permission had already destroyed 208,481 of its files between July 1983 and May 1984. With the appearance of the new spy agency [the Canadian Security Intelligence Service (CSIS), which assumed intelligence duties split off from the RCMP, a decision was made to transfer some of the records to the National Archives of Canada. In 1987, CSIS created the National Archives Requirements Unit to review the documents in consultation with archivists. Out of nearly 500,000 records, 440,000 were destroyed. Twenty-nine thousand made the trip to the archives and 28,000 were retained at CSIS because of continuing value (207).

Such developments have made a full accounting of state repression of left-wing movements in the 1970s all the more difficult, while the scale of information destroyed suggests that the phenomenon was widespread. 
(October 1982), and others. ${ }^{77} 78$ Efforts were also made to keep abreast and inform others about the work of feminists in countries facing imperialist domination. This typically took the form of republishing articles, interviewing women, publishing summaries of ongoing struggles, and when possible bringing speakers from overseas.

Socialist feminists produced analyses which identified the underlying political and economic reasons for war taking place at that time and linked them to the broader class struggle. Prominent socialist feminist Dorothy Smith criticized the Left's inability to theorize the causes of the wars and conflicts of the day. She argued, "the notions of class and class struggle must be central. When we, as socialists, look at issues of peace and imperialist oppression, we're looking at class" (Smith 1984: 3). Smith (1984) continued,

When we talk about class in the context of capitalism, we're talking about relations which organize the exploitation of the mass of people in the interests of the self-expansion of capital. The mass of capital in the world increases as a result of exploited labour. It is controlled by forms of ownership that increase the powers of those who command capital rather than returning it to the benefit of those who create it. These relations organize our powerlessness before the threat of nuclear war, of technological unemployment, of the multiple oppressions of imperialism. These powers are organized on a global level...This is a period of the increasing centralization of capital on a global scale. We are seeing the emergence of an internationally structured workingclass, with a division of labour between a highly skilled and highly paid elite of

77 Others include the March Against War in Central America (October 1982), Wald-a-thon for Salvadoran Refugees (May 1982), and Women's Liberation, Disarmament and Anti-Imperialism Forum (March 1983).

${ }^{78}$ All of these events were promoted and supported in the International Women's Day Committee Newsletter (1980, 1982a, 1982c, 1982d, 1982e, 1982f, 1983e). 
workers in the First World and workers in labour intensive industries and services in both First and Third Worlds (4).

Smith (1984) persuasively argued for the necessity of a socialist movement to overcome the tendency towards war inherent in capitalism and the constant drive to increase and maintain profits. While the idea that war and imperialism have their roots in capitalism's drive for expansion was not new to socialists, the link was not accepted by the women's movement broadly. Socialist feminists' anti-imperialist stance was met with frequent opposition from liberal, and sometimes radical, feminists who rejected the connection between the Canadian feminist movement and movements for national self-determination and socialism. This position is perhaps best illustrated by Lowenberger's 1983 article in Broadside. While Lowenberger criticized International Women's Day (1983) for being too “oriented towards the male left" (14), her more specific criticisms were aimed at IWD's focus on antiimperialism which the article claimed was "divisive" and "insensitive."

The idea that feminist organizing should not include international solidarity with those fighting against imperialism was a common liberal feminist position. The implication was that women in Canada and abroad had no reasons of their own to be involved in struggle against imperialism, since men generally, or simply specific policies targeting women, were the source of their oppression. Lowenberger (1983) argued that the politics taken up by IWDC in Toronto reflected those women's efforts to be 'like the men' and prioritize issues seen as "male-oriented", writing,

I see no necessary relationship between feminism and anti-imperialism, antiZionism or national liberation. The mere fact that national liberation movements allow women to fight and die in them is an insufficient reason for 
feminists to embrace them. The Iranian and Algerian revolutions are examples of movements where women were in the forefront and are now severely repressed...the March 8 Coalition made no attempt to apply a feminist analysis to the Middle East struggle. Instead, it swallowed the rhetoric which holds that the Palestine Liberation Organization is good and Israel is bad...A lack of feminist analysis led to the focus on national liberation movements preferred by the male left, rather than on women's oppression...International Women's Day is increasingly becoming dominated by male-oriented leftist issues, to the exclusion of feminist issues. The handling of the national liberation movements discussed above is one example of this, as is the increasing number of men who insist on participating in the march (14).

Thus Lowenberger (1983) made clear the political stance of the liberal feminist movement, dismissing the revolutionary activity in Iran against the US-backed dictatorship of the Shah, in Algeria against French colonial dominance, and in Palestine against Israel's colonial oppression leading up to the First Intifada. Socialist feminists' support for liberation struggles demonstrated their commitment to ending this oppression. Lowenberger's suggestion that women in countries resisting imperialism were simply cannon fodder for male leftists denied those women any autonomy. She suggests that women militants did not understand the importance of the struggles of which they were part. Further, she suggests the existence of a 'universal feminist politic' that could unite all women, if only the "male-oriented" issues would be dropped. This is ironic in light of the fact that refusing to support international struggles would have alienated whole strata of women from the movement. 
In the same issue of Broadside, Mary O'Brien and Freida Forman of the Toronto Women's Research-Resource Centre wrote in to express their similar concerns that "feminism as analysis and perspective [were] absent" from IWD 1983. "More alarming still," they said, "was the introduction of a highly divisive and deeply controversial issue: The Middle East (reduced at the rally to a Palestinian struggle only)" (2). Lowenberger, O'Brien and Forman in this way implied that feminists should endorse, or at least not oppose, the illegal Israeli occupation of Palestine - a position that may have been divisive to Israeli women. The insistence that feminism should not be concerned with anti-imperialism or other "leftist" issues is consistent with the previous liberal women's movements. For Lowenberger, O'Brien, and Forman, there was no clear connection between women's fight for issues like reproductive rights and equal pay and the Israel-Palestine struggle (Pierson 1995). They were correct that, technically, these struggles are not connected, ${ }^{79}$ but socialist feminists saw the struggle for women's liberation as tied to the struggle for socialism. Marxists viewed internationalism as integral to building socialism, and Canada's imperialist policies threatened this. Pierson (1995) writes, "by 1983, recognition as growing that racism, imperialism, and militarism were at the core of the oppression of women in colonized and brutally militarized parts of the world" (365). Furthermore, IWD was, from the beginning, a socialist and anti-war event driven by communist and socialist organizers. Besides this, socialist feminists could easily respond with the question, "What about Palestinian women?"

\footnotetext{
${ }^{79}$ The same thing can be said about how the call for abortion wasn't exactly linked to the overthrow of capitalism.
} 
In response to the accusations that IWD did not represent feminist politics, IWDC wrote a response both in Broadside and in their newsletter. In both, they described how anti-imperialist struggles must be tied to feminist concerns. First, in Broadside, they addressed their conception of how women's oppression is conditioned by imperialism:

We believe that while women's subordination is a fact throughout most of human history and in most parts of the world, it takes very different forms and is conditioned by many different factors. And that is the first reason why we raised the question of imperialism: for many women in the world, it is a key structure of their oppression as women...Therefore, we must take exception to Lowenberger's statement that there is no necessary relationship between feminism and anti-imperialism, for the fact is that, for many Third World women, the two are bound up so closely together as to be inseparable in their lives and in their politics (IWDC 1983b: 2).

In the IWDC Newsletter, socialist feminists took their position a step further to argue that, not only is anti-imperialism a feminist cause in support of Third World women, but that imperialism also negatively affects Canadian women. IWDC argued that massive buildup of armaments and arms race, especially the proliferation of nuclear weapons, was a threat to women in all countries:

An anti-imperialist and anti-nuclear position is not only taken in support of our sisters' struggle against the conditions oppressing them, but also in our own interests. Military aggression and a nuclear arms buildup curb our rights as women daily, and may finally eliminate them altogether (IWDC 1983a: 2).

This response did not clearly outline how they saw the militarism affecting women in Canada, but in a later issue of the IWDC Newsletter the organization expanded its 
analysis to include the financial burden that Canadian militarism places on social services:

We are all frightened by the potential devastation of a nuclear war. But even today, we are suffering from the economic effects of militarism. Over the past 3 years, our government has cut social services in order to finance a military budget which has increased 60\%. For every dollar cut from education and health, $\$ 1.10$ has been added to military spending...The struggles for national self-determination and for women's rights have been held in check by the military aggression of the superpowers (IWDC 1983c: 2).

Still missing was a more developed understanding of Canada's role as a junior partner to US imperialism. Also missing in the statements responding to Lowenberger, O'Brien and Forman, was an analysis of the prevailing political, economic, and social conditions of women in Algeria, Iran, and Palestine. This would have contributed to highlighting the limitations of liberal/radical feminism and helping to inform readers of the significance of the anti-colonial struggles in those countries for women. However, such data may not have been available.

Two months after International Women's Day 1983, women from IWDC held a conference to discuss the various positions on anti-imperialism that were put forward after the controversy of that year's event, inviting Lowenberger and others to speak. This in itself demonstrates the lengths to which socialist feminists went to find common ground with other feminists. They held events like this one to help women see the limitations of liberal feminism. In summarizing the event, Gottlieb (1983) wrote, "While we reached no unanimous conclusions, one thing was clear: we have many things to discuss and despite our fears we made a good, if tentative, 
beginning" (2). Predictably, no common ground was found because the two positions

- liberal/radical and socialist feminist - were incompatible. Furthermore, giving a platform to Lowenberger's positions may have further alienated women in the movement who understood national liberation to be central to women's liberation in countries oppressed by imperialism - a position that was widespread within the socialist and communist movement, and one that socialist feminists worked to bring to the women's movement. In the following section, I'll show how similar tensions arose between racialized, immigrant, and Indigenous women, and the existing feminist movement from which they felt excluded. Although they prided themselves on taking up many of the broader socialist movement's anti-imperialist positions, socialist feminists increasingly found themselves under criticism for lack of inclusion of women from oppressed communities, and further found themselves embroiled in the disputes over who feminism serves and who it excludes.

\subsection{Relation to Anti-Racist and Anti-Colonialist Organizing}

A number of socialist feminists that I interviewed identified anti-racist work as among the most important work in which they and/or other socialist feminists were involved. At the same time, many of the same people mentioned that, despite this work, one of the biggest criticisms their organizations received was that they never considered race at all or did so insufficiently. While most women I spoke to refuted the accusation that their organizations never considered race and racial oppression, many also admitted they were never quite sure of how to organize in response to this issue: 
“[People] think that second wavers did nothing to fight racism and that isn't true. What is true is that we tried but we didn't know what we were doing so we made a lot of mistakes...[I understood racism as] fighting the state against racism but I didn't know it as transforming an organization and how much tensions there were around that...We tried and we did it very dramatically [in NAC] and there was a big backlash...and we didn't know how to handle it. We just didn't have the skills." 8081

“I think [our anti-racism work] wasn't very deep. We tried a little bit and since that time, I've done a lot more...but we didn't really understand it then. I don't think socialism or the socialist feminist movement understood race sufficiently in those years." ${ }^{82}$

"Socialist feminism has also made an argument for an inclusive politics that says you have to recognize racialized [and] colonized [peoples]. If you want to build an effective political movement it has to include and speak from the politics of the diversity of people...There's a debate at how effective socialist feminism has been at that and whether it has been or not and, I think, some anti-racism feminists would say socialist feminists haven't been that good at it." 83

"To be honest, I think racism was definitely on our radar and we definitely saw ourselves and identified ourselves as struggling against racism, but I would say that we had a particular framework for understanding that and I think that

\footnotetext{
${ }^{80}$ Rebick, interview with researcher, August 6, 2018.

${ }^{81}$ Rebick attributes the fall of NAC to both a cut in government funding but also the racism that was prevalent. The leadership in NAC had worked hard to create designated spots on the executive for women of colour, Indigenous women, and disabled women. She argues, "overnight NAC was transformed. It worked but it created a lot of stress...There was polarization in the executive between women of colour and white women...We underestimated how much racism there would be." In particular, Rebick remembers that members of NAC and the media wrote off Sunera Thobani, who was president after her from $(1993$ - 1996) because of their racism.

${ }^{82}$ Field, interview with author, November 8, 2018.

${ }^{83}$ Luxton, interview with author, July 19, 2018.
} 
framework was a solidarity framework. Which was similar to the antiimperialist work that we were doing...I think the critique to be made of that was that we didn't see ourselves as involved in that. We were in solidarity with people that were "over there" and that right from the beginning identifies us as seeing ourselves as white and more importantly, we see ourselves in solidarity with people struggling against racism, but we don't see the ways that we ourselves are part of the problem. The ways in which we act out, in our everyday lives, white supremacy." 84

"I really do see socialist feminism as trying to combine, maybe in an early way, what people call intersectionality today - consciousness of culture, ethnicity, as well as gender." 85

One of the challenges of talking about anti-racist work in the 1960s - 1980s is that what constituted "anti-racist politics" in that period was not the same as the antiracist activism of the present. While socialist feminists' publications like the IWDC Newsletter, Rebel Girls' Rag, and Cayenne all expressed anti-racism as a core value, the work of socialist feminists around anti-racism, as Gottlieb points out, was mostly based on being in solidarity with "others." There was little understanding of how socialist feminists' own actions and organizations could contribute to the problem of racism. The limitations of a "solidarity" approach to anti-racist organizing came to the fore during the planning of International Women's Day in 1986. This event is discussed in detail below and it highlights how much of the anti-racist work being done by socialist feminists was just trying to come to terms with racism and then

\footnotetext{
${ }^{84}$ Gottlieb, interview with author, December 6, 2018.

${ }^{85}$ Kealey, interview with author, August 13, 2018.
} 
educating other white women. This work, as Black women pointed out, was the bare minimum in terms of anti-racist organizing.

While some racialized women organized as socialist feminists, notably Rosemary Brown, the movement itself was largely 'white' and therefore most women lacked the direct experience of racial oppression. ${ }^{86}$ My own survey of socialist feminist publications (Cayenne, Rebel Girls Rag, OtherWoman, IWDC Newsletter) suggests that socialist feminists did not shy away from this fact and acknowledged it as a weakness. For example, socialist feminists admitted to being relatively unaware of the struggles of Indigenous women in an issue of Cayenne (1985):

For the most part, we in the women's movement know very little about the lives, pain, laughter, anger, creativity and struggles of native women. We do hear about the issues that make headlines - the struggle to recognize women in the Indian Act, the heroic actions of women demanding an end to the kidnapping of their children by state agencies in this country, the murder of AIM activists like Anna Mae Aquash in the U.S. - and many of us have tried to work to support those struggles. Yet native women remain for the most part, invisible (19).

Indeed, colonization or settler-colonialism featured little in the analysis of socialist feminist publications and, when it did it appear, it was typically in response to colonialism in the Global South. In this vein, socialist feminists, and indeed most of the movement, lacked an analysis of how colonialism/settler-colonialism structured

\footnotetext{
${ }^{86}$ All the women interviewed for this project would be considered 'white,' so this dissertation is limited in its analysis as it lacks interview data from racialized women. This is both a reflection of socialist feminist limitations, the ineffectiveness of my snowball sampling, and a sign that racialized women didn't organize in these groups. It is also important to note that there were numerous racialized women who were socialists and communists but who still did not identify as "socialist feminist."
} 
Canadian society and, indeed, structured gender relations in Canada. Socialist feminists did reflect, however, on their tendency to understand racial oppression as separate from other issues. Instead of seeing racial oppression as structuring all the issues they worked on, analysis of racism was too often relegated to its own separate category, something recognized by the IWDC:

For many years, the March 8th Coalition has tried to give attention to the special oppression of women of colour and immigrant women. At first, we dealt with these issues in a separate section of the leaflet and, in particular, forums or activities. Later, we tried to overcome 'tokenism' by referring specifically to the impact on women of colour and immigrant women whenever we discussed any feminist issue. Nevertheless, many women have felt that, issues of racism somehow tended to 'get lost' (IWDC 1986: 3).

As the above statement hints, the nod to racial oppression when discussing feminist issues in publications and at rallies was insufficient to convince many racialized women that socialist feminists were indeed allies. This particular statement was issued after a conflict arose between Black, Indigenous, and white women in the organizing of the International Women's Day 1986. It suggests that collectives consisting of primarily white Canadians, regardless of whether they were socialist or not, had to be pushed on issues of racism and colonialism before they fully integrated that analysis. The Toronto Black Women's Collective (1986a) argued, "individual awareness of the problem is "the beginning of the process" of understanding racism for white women (31). The next step is, "verbalizing the problem...followed thereafter by collective awareness of the group" (Toronto Black Women's Collective 1986a: 30). In this way, anti-racist activists pointed out that the bare minimum that white women 
could do was to raise collective awareness about racism. Despite the efforts of socialist feminists to integrate some of this anti-racist analysis into their work, the tensions that arose around International Women's Day often reflected their weaknesses and oversights in this area, and difficulty in turning their own selfcriticism and acknowledgement of weakness into concrete action.

In 1985, the March 8 Coalition $^{87}$ decided that the theme of International Women's Day 1986 would be 'No to Racism', with the main slogan as 'No to Racism from Toronto to South Africa.' Part of the reason for this choice was that the struggle against apartheid in South Africa was becoming increasingly visible in Canada and in mainstream consciousness internationally. Canadian governments had long supported apartheid in South Africa in myriad ways, and Canada was cited as an early model for apartheid due to its treatment of First Nations, in particular the reserve system (Freeman 1997). Canadian companies were also heavily invested in South Africa and benefitting from the cheap labour of Black South Africans (Engler 2015; Engler 2013). Likewise, racism and colonialism in Canada was widespread and relatively unchallenged, including many incidents of racist and colonialist violence during the 1970s and 1980s and RCMP killings. Attacks had led to the deaths of many south Asian and Black Canadian and Indigenous youth including Buddy Evans (1978), Albert Johnson (1979) and others, causing outrage from people in those communities and Canadians from all backgrounds (Barrett 2017; Ontario Human Rights Commission).

\footnotetext{
87 This was also the year that IWDC officially stepped down as organizers of the March $8^{\text {th }}$ Coalition, but they and other socialist feminists were subsequently still heavily involved in the organizing process.
} 
The choice of anti-racism as the theme for IWD prompted Black and Indigenous activists who were not previously involved in IWD to become involved in organizing efforts. In particular, the Toronto Black Women's Collective (TBWC) and Native Women's Resource Centre (NWRC) involved themselves in the process. TBWC (1986b) saw the "theme as a genuine" and welcomed "effort on the part of our white sisters to come to terms with racism in the women's movement and to put their labour and their feet where their mouth was on sisterhood" (n.p). TBWC commended the organizers "on their courage, because it is not easy to fight against racism" (n.p). The organization also noted that despite the Coalition's efforts, that they found it "extremely difficult" to organize even with "the most together white feminists" many who had never closely worked with Black women (TBWC 1986b). The Collective noted,

This coalition from our point of view has only organized white women over the last ten years. In selecting this theme [anti-racism], perhaps it was not fully aware of the step that it was taking. Simply, it was seeking to organize Black women. Did the Coalition consider how it would have to change in order to do so? ... The step of choosing this theme shows interest, shows concern, but it is just a first step (Black Women's Collective Toronto 1986a: 31)

In an interview with Rebick (2017), Dionne Brand (2017) talked about how the Black Women's Collective shook up the Coalition that year by inviting Indigenous women and Native Women's groups. She explains the tension that ensued:

There were capable women who had run IWD for a long time, and the bureaucracy of it was well in hand. So, we came in conflict with some of the ways they did things. Suddenly it was very charged...I do think that the vision 
of us, 10 Black women, walking into the room was scary for people, and that played to our paranoia...We are in the weakest position, so how could we be scary? I think we had allies, and I don't think the women who were upset with us were against us. I also think there were women who admired us...I don't think anyone coming into the room was who they were before. It was a transformative time...Some white women threw their hands up in the air because they lost control and so felt they couldn't do anything. They withdrew their goodwill...(as quoted by Rebick 2017: n.p).

One of the main conflicts revolved around existing Coalition members' right to vote on issues that affected Indigenous and racialized women. Members of the Native Women's Resource Centre argued that the vote was not compatible with their communities' forms of decision-making. Women from the Black Women's Collective (1986b) further argued that the vote "would disenfranchise the Black and Native women in the room" and that the primarily white women had no right to vote on "issues that had nothing to do with their lives" (n.p). White women's need for further education on racism and colonialism was ultimately impeding the ability of racialized and Indigenous women to effectively organize in the Coalition, they argued. In that vein, the TBWC argued that "what the coalition needed to do was some workshops for white women about racism. Not where the black women and women of colour come in and say what racism is, but white women sitting down with each other and talking about how it works" (Brand as quoted by Rebick 2017: n.p). Faith Nolan (1986) writes, "time was needed for [white women] to acknowledge and deal with their own racism. The identification of the fact that racism was alive and well among them led to hostility and resentment within the ranks and towards the Black 
Women's Collective (Nolan 1987). Ultimately, the proposal for workshops on racism led by white women for white women was rejected.

The events leading up to the 1986 International Women's Day march led to self-reflection on the part of socialist feminists - in particular, those involved in the March $8^{\text {th }}$ Coalition and the newly-renamed Toronto Socialist Feminist Action. Jennifer Stephen (1989) wrote about the limitations of TSFA's politics in Rebel Girls' Rag and spoke about the organization's new commitment to anti-racist organizing:

In TSFA we have recognized that it is essential that we take up an anti-racist politic and work to implement that politic in our practice. We participated in the 1986 March 8th Coalition, which was the first time the women's movement in Toronto was forced to respond to the reality that racism is one of the greatest barriers to achieving full unity among women. It is crucial that we as socialist feminists incorporate a systematic analysis of racism into our politics (1989: 3).

The recognition that racism was one of the "greatest barriers to achieving full unity among women" meant that if socialist feminists were to commit to a broad coalition politics, they would need to overcome racism inherent in their own practices. One way that TSFA did this was to respond to the backlash from some white women with regards to criticism from other participants in IWD. Their aim was to publish a response that confronted them in a way that would educate these women on racism. Women from the IWDC Newsletter published an article called "Some White Women's Response to March 8," which recognized that socialist feminists' own organization(s), and the women's movement more broadly, had not been inclusive. The article argued the necessity of white women in the movement understanding how oppression was 
structured in differing ways depending on race, class, gender, nationality, and sexuality:

We understand that being white gives us a commonality, and that as white women we must deal with both the personal privilege and structures of racism in a heterosexist, racist, class society, and within the women's movement. We also have differences of class, sexuality, national origins, and experiences of oppression, which impact on our lives in different ways, and our political outlooks. We recognize that the women's movement has not integrated an anti-racist perspective and we must be self-critical of that. We accept the criticisms of South Asian, native, black, Chinese and other women of colour that the movement hasn't been open to them...It is the responsibility of white women and the women's movement to fight racism. We accept the need to educate ourselves on racism in order to take up this fight. We strongly endorse the anti-racist politic that was developed with the leadership of women of colour in the March 8th leaflet. We also support the general perspective that was articulated in the coalition speech, particularly the need to build a new women's movement with the participation and leadership of South Asian, native, black, Chinese and other women of colour. The women's movement must be self-critical of its history in this regard...Mistakes have been made, and we want to commit ourselves to working self-critically on the development of a truly anti-racist feminism (IWDC 1986: 21).

The statement both acknowledges the relative absence of racialized and Indigenous women in the women's movement, and the larger structural oppressions that these women face. Socialist feminists also tried to ensure the issue was not reduced to personal guilt about racism because, as they saw it, the alternative was to stop engaging in politics, which would solve nothing. This was articulated by Maria Lorenzo (1986): 
The worst thing that could happen to us as socialist feminists is that our guilt about our racism should immobilize us to the extent that we fear in engaging in real political discussion and debate, or fear to challenge those with whom we have serious political differences. In the long run, this would only constitute a disservice to our sisters of colour - and to ourselves (42).

This approach of acknowledging and responding to racism, even when uncomfortable and challenging, was important in a time when such conflicts or criticism at times resulted in white women retreating from the movement. In the same article, Lorenzo (1986) argues that the "real propagators of racism are...not inside the women's movement, but outside in the state and economic structures that shape and limit all our lives...But when the understandable anger of women of colour at white women's racism threatens to create unbridgeable chasms between us, it is important that we not be guilted into political silence (Lorenzo 1986: 41-42)." Among the debates consuming the women's movement, this was an important reminder. While women found themselves at odds in the women's movement based on race, including the movement's approach and efforts to collaborate with oppressed communities, the greatest danger was for the structural oppression committed by the state (genocide of Indigenous people, economic exploitation of the working-class, imperialist wars on the Global South, police violence and murder, etc.) go unchallenged. However, Lorenzo's emphasis on the "real propagators of racism" was criticized by socialist feminists Rachel Epstein and Jenny Horsman for downplaying white women's racism and suggesting racialized women were being "divisive, disruptive, [and] overlysensitive" when IWD events that year became heated. Sangster (2010b) argues, "while tensions and inequalities based on race, class, and colonialism certainly 
existed in feminist, New Left, and anti-racist organizing...they were also points of debate and struggle" (3). Socialist feminists' attempts to integrate race, class, and gender into one analysis often emphasized the common ground that anti-racist struggle had with women's struggle. The March $8^{\text {th }}$ Collective (1986) argued this succinctly,

We do not believe that racism is merely a misunderstanding among people, a question of interpersonal relations or an unchanging part of human nature. It is, like sexism, an integral part of the political and economic system under which we live. We cannot just educate racism away. Even legal reforms are not enough. We must take racism to its material roots and change the economic and political structures which maintain it (n.p.).

Socialist feminist and IWDC organizer Sherie Macdonald also emphasized "the role of the ruling class in maintaining and propagating racism as well as sexism" and "underlined the need to struggle against a common enemy" (Fourt 1986: 28). In her own words, "white women, we're here to say to you that the fight against racism is your fight, too. Because whether we're talking about fighting racism or sexism, we're talking about changing the very nature of the political and economic system under which we live" (Macdonald 1986: 36). Macdonald underscored how corporations benefitted from paying racialized workers less and using them as a reserve army of labour. One of the problems with this analysis is that it repeats "an assumption of automatic sisterhood from white women towards black women" because of a shared oppressor but "sisterhood can only be nurtured and developed when white women acknowledge the complex power relationships between white women and white men in relation to black women and black men" (Bhavnani and Coulson 2005: 96). 
Racialized women, confronting what they saw as a lack of understanding in the feminist movement, forced conversations about race and prompted socialist feminists to address this weakness in their political work.

Despite the efforts of socialist feminists after IWD 1986, there are indications that problems persisted in how racialized women were treated in majority-white collectives, unions, and organizations. One year later, an example was given by Pauline Peters, who accused the Toronto Women's Bookstore (TWB) of tokenism and racism after she presented the collective with a series of suggestions on how to involve more black women in the organization. Peters argued that her proposal was met "coldly and critically" (Peters 1987: 12). Members of Our Lives, the newspaper collective of which Peters was a member, called for a boycott of the bookstore. While the TWB was not a socialist feminist business, it was supported by socialist feminists who later chose to run a rebuttal to Peters' article in Rebel Girls' Rag. The article argued that the TWB was "actively involved in anti-racist work in Toronto..." and that Peters "marginalized and also made invisible the contributions of the South Asian woman...white working-class members" and two black women of the bookstore (Fernandez, Julian, Johnston, Lawrence, McAuley, McCallum, Martin, Opperman, Vise, Wine 1987b: 2-3). Conflicts such as these led many Black women to create their own feminist/womanist newspapers, magazines, and organizations in the 1970s and 1980s, including Our Lives, Tiger Lily and Womanist, the Black Women's Collective, Lesbians of Colour, and the Congress of Black Women. These organizations allowed black women to address their absence in other feminist publications and 
organizations as well as their conviction that existing organizations were not meeting their needs and aspirations.

\subsection{Labour Issues}

Affinity with labour struggles was a major component of socialist feminist organizing throughout the 1970s and 1980s. However, socialist feminist focus on labour activism was not as strongly emphasized as was the case in traditional leftwing parties and politics, or, rather, was emphasized differently. This is not to say that socialist feminists did not support these struggles, or were not involved in their trade union locals, or that they lost touch with the importance of class. Instead, the socialist feminist approach to labour struggles reflected a central aspect of its political analysis and approach to class, which saw the latter as encompassing and structuring women's lives in a multitude of ways. Thus, organizing for daycares and abortion access were considered just as integral to socialism as organizing in the trade union movement, and as much of a "class issue." That being said, many of the women I spoke to were involved in trade union struggles, and indeed, such struggles were many women's central focus and where they spent the most energy organizing.

One example was the organizing work of Debbie Field, a socialist feminist who worked as OPSEU's Equal Opportunities Coordinator and later organized workers to oppose Hamilton-based Steel Company of Canada's (Stelco) discriminatory nowomen hiring policy. During the Second World War, Stelco relied on women's labour to continue production (United Steelworkers n.d.; Luxton and Corman 1991). However, after the war, Stelco implemented an unofficial no-women hiring policy which continued for decades. Some of the women hired at Stelco during the war 
remained at their jobs, while others were pushed out, and no new women were hired (Luxton and Corman 1991). Field helped to found the "Women Back Into Stelco Committee," the purpose of which was to fight this sexist and discriminatory company policy. Field became an organizer in this campaign through her involvement in the Revolutionary Worker's League (RWL):

The RMG fused with the LSA and created a new group called the RWL...Inside our combined organization, the LSA people were really pushing this idea that we needed to make a turn to industry. [They argued] the way the revolution was going to happen is all of us being embedded in industry rather than other working-class jobs. So, there was a big pressure on women...to make a turn to industry. Part of why I went to Stelco was because there was pressure on leaders...to get industrial jobs. In hindsight, it's just ludicrous to imagine what some of us were doing. Actually, a lot of people's lives got messed up because they gave up good jobs as teachers or white-collar jobs and went into the bluecollar situation and either got laid off or it didn't last very long. 8889

The Women Back Into Stelco campaign was also supported by the United Steelworkers of America (USWA) Local 1005, the union representing Stelco workers (Luxton and Corman 1991). RWL, like many groups at the time, was focused on organizing industrial workers. Field and another party member were sent into Stelco as salts. "Salting" is a process whereby a trade union or political organization asks a member or volunteer to apply to one or more workplaces in order to organize a union or, in this case, to organize women against this discrimination. While the work was difficult and conditions were less than ideal, Stelco was one of the largest and best-

\footnotetext{
${ }^{88}$ Field, interview with author, November 8, 2018.

${ }^{89}$ Field's comments reflect real divisions within the socialist and labour movement about who counted as the real working class. While clerical and professional jobs were ripe for further organizing, the RWL and other groups saw workers' salvation in the industrial proletariat.
} 
paying employers in Hamilton (Luxton and Corman 1991). Thanks to the strike struggles waged in the 1950s, working at Stelco was a way for workers to secure a decent living for themselves and their families. The campaign to bring women back into Stelco was successful at launching a Human Rights Complaint, and Field and others were hired on (Briskin and Weir 1981). ${ }^{90}$ Field was interviewed about the campaign in a documentary produced by socialist feminists Linda Briskin and Lorna Weir. She made no attempt to glamorize the exploitation of Stelco workers, but made the case that women are equally capable of doing the work. She explains,

I can do the work and handle the dirt and smoke...the same way the men can...I don't like it, but I don't think any of them do either...It's very depressing to work there...You feel your life really being drifted away by the work process (in Briskin and Weir 1981).

During my own interview with Field, she told me that after the Women Back Into Stelco Committee's victory, when women entered the workforce they were greeted with cheers and applause from the male workers. At the same time, tensions developed in the workplace as women demanded that the culture of workplace sexism and workplace harassment be addressed (Marr 2007). This included opposing the habit of male workers putting up pornographic or suggestive "pin-ups" in the shop. ${ }^{91}$

Additionally, women members faced sexist discrimination in the trade union movement. The idea persisted that women's labour issues (pay equity,

\footnotetext{
${ }^{90}$ Many of the employment gains that Stelco women won were later rolled back because of major layoffs (Luxton and Corman 1991).

${ }^{91}$ Field, interview with author, November 8, 2018.
} 
unemployment, working conditions) were secondary to men's issues because women were presumed to be "secondary wage earners." Women's objection to this line of thinking was put succinctly by Saskatchewan Working Women (SWW), "the suggestion that unemployment among women isn't a serious problem because we're only secondary wage earners is a serious threat to our basic right to work. If we fail to defend this right, we lose our basis for financial independence and thereby suffer a severe setback in the fight for equality" (1979).

Barbara Cameron recalls the sexism that women faced in the Ontario Federation of Labour, "I've heard a tape of Evelyn [Armstrong] getting up at an Ontario Federation of Labour convention in the 1970s. The catcalls that faced a woman speaking at a labour convention then seems unbelievable today. All kinds of sexist comments were being yelled out" (as quoted by Rebick 2005: 94). Similarly, Field and Kathlyn Petersen remember this treatment while organizing in the OFL, Canadian Labour Congress (CLC), and Canadian Union for Public Employees (CUPE). Petersen and Field recall that it was common for women to be shoved, yelled at, laughed at, catcalled, and harassed -- something they experienced when they and other women tried to organize a caucus to address their specific concerns:

"When we first got on the floor for childcare at a convention for CUPE we were harassed off the floor by the men. There was swearing and just viciousness. It totally shocked me because in most left organizations there's not that kind of verbal nastiness. But eventually we did get childcare at convention and we did get women's caucuses, LGBT caucus, black and Indigenous caucuses." 92

\footnotetext{
92 Petersen, interview with author, August 31, 2018.
} 
"We began to caucus everywhere. That was the way we started to create a socialist feminist movement in the union movement...We would talk about daycare or sexual harassment or negotiating for issues that were relevant to women and often the guys would just make fun of us. It was very hard to get this organized in a way that worked for us and that's why we needed to create caucuses. My biggest experience was in OPSEU...it was there that we eventually created a caucus which created this position that I was involved in - the Equal Opportunities Coordinator - because we felt that we needed something like that to better integrate women into the union movement." 93

Field, Cameron, and other socialist feminists were involved in an organization called Organized Working Women (OWW) which in 1977 "organized the first 'Women's Caucus' in the history of the OFL" (Kirkconnell, Craig, McDermott, and McPhail 2018). OWW was founded a year earlier, and "put on workshops, conferences and educational programs in the Toronto Area for trade union women" (OWW pamphlet). According to Field, OWW "became a current in the union movement that tried to pull together all socialist feminist currents." ${ }^{\text {4 }}$ The OWW also "prepared resolutions to go to Ontario Federation of Labour conventions" and organized members "on the floors of conventions to push labour to take up women's demands" (Cameron as quoted by Rebick 2005: 94). Along with socialist feminists, the OWW included many members of the Communist Party (Rebick 2005: 95). OWW also organized support for labour from within the women's movement. Cameron, then a member of the CPC, credits OWW for bringing "the women's movement into support for the struggles of labour women" (as quoted by Rebick 2005: 94). Women also

\footnotetext{
${ }^{93}$ Field, interview with author, November 8, 2018.

${ }^{94}$ Field, interview with author, November 8, 2018.
} 
fought hard to have their concerns heard in the CLC. As a result, in the 1980s, resolutions were passed at CLC meetings to endorse "woman's freedom of choice in supporting the right of women to full access to abortion" and "removal of abortion from the Criminal Code" (IWDC 1982b: 4).

Socialist feminists saw maternity leave as a basic demand for women's economic independence and "full integration into social production" (RWL 1979). They celebrated gains to maternity leave in Cayenne, Rebel Girls' Rag, and publications by the RWL, LSA, and RMG. For them, maternity leave was essential but insufficient (in and of itself) in the fight for women's liberation. After many years of stagnation, the fight for maternity leave was rejuvenated in the 1960s as more women entered the labour force. These new women workers demanded they not be "penalized or discriminated against because of their reproductive responsibilities (de Wolff 2006: 101). ${ }^{95}$ Rosemary Waskett (2012) explains, "before paid maternity leave" it was expected that women leave their jobs out of "moral" responsibility for their children and families (n.p). Working women, some of whom were socialist feminists, supported the demand for maternity leave in unions (CUPW, PSAC, CALFAA, CWC, USW), the labour movement (OWW, Saskatchewan Working Women, CLC), women's organizations (IWDC, OCAC, NAC) and within political parties (NDP, CPC). In 1971, "unemployment insurance was extended to include maternity leave. Mothers could claim up to 15 weeks of benefits," but many mothers could not afford to take it because their income would be too low (Floresco 2012: n.p). The labour movement

\footnotetext{
95 The last big win for maternity leave had come in 1921, when the Maternity Protection Act was introduced in British Columbia. In the 1940s and 1950s there were unsuccessful attempts to extend maternity leave and get unemployment insurance benefits to cover maternity leave Floresco 2012).
} 
"saw maternity leave as a benefit it could improve through contract negotiations" (Floresco 2012: n.p). They were correct. In the late 1970s, trade unions in Quebec formed the Common Front, which successfully negotiated maternity leave and other demands with the Quebec government. These gains inspired "feminists and unionists in the rest of Canada" (Floresco 2012: n.p) and, in 1981, the Canadian Union for Postal Workers (CUPW) went on strike demanding paid maternity leave. Socialist feminists, communists, and women's organizations joined the picket line. CUPW "was the first national union" to achieve maternity leave for its workers. The union negotiated 17 weeks of paid maternity leave which "set a precedent that cleared the way for similar arguments in other public and private sector workplaces across the country" (de Wolff 2006: 102). Shortly thereafter, telecommunications workers, CWC (Local 42), won a similar contract and "throughout the 1980s maternity leave spread to broader public sector, armed forces, and RCMP" (Floresco 2012: n.p). Gains to maternity leave "continued, but at a slower pace" and in the 1990s benefits extended to families who chose adoption and to same sex couples (Floresco 2012: n.p).

Socialist feminists also paid attention to specific trends in technology and the economy they saw as threatening to impact women's livelihoods. In this way, the issue of "microtechnology" and further automation became an important factor in women's organizing and mobilizing in the women's and workers' movement in the 1970s and 1980s. At that time, the mass production and introduction of microchips was dramatically improving the affordability and effectiveness of various technologies used in industry. IWDC's Trade Union Committee raised concerns that these technological changes would eliminate many of the jobs done by women, affect 
the health of workers by isolating them from one another, and increase surveillance of workers through "keystroke supervision or monitoring" that would cause undue stress and physical problems (Pelletier and the Women and Technology Committee 1983: 68). Women workers' concerns about these changes mirror many of the concerns of workers today about further elimination of jobs in favour of automation. Furthermore, they identified that women would bear the brunt of this new high-tech manufacturing. In 1982, some members of the committee worked with trade union women to raise the issue at the OFL. The IWDC distributed a leaflet describing the committee's concerns:

The microtechnology industry is going to have very serious and negative effects on women and women's struggle for equality. Women, particularly immigrant and third world women, are being exploited at piece work wages to assemble silicon chips in non-unionized factories. And the technological advances made possible by the microchip industry will be used to literally transform the sectors where the majority of women work. It has already started; office and service jobs are the prime targets. The effect on women, in our struggle for jobs, equality and improved working conditions, is going to be dramatic and potentially devastating as the ground for struggle shifts and changes under our feet (IWDC 1982a: 3).

The IWDC also partnered with the Ontario Public Service Employees Union (OPSEU) to premiere Laura Sky's 1982 film Good Monday Morning, which documented the "frustrations, fears, hopes and responses of women office workers...centered around the impact of new technology in the office, the consequent de-skilling of women's jobs and the health and safety concerns related to video display terminals (VDTs)" (Steffen 
1988: 68). IWDC and OPSEU then presented joint workshops on these issues to several trade union locals and other groups (IWDC 1982a).

Continuing to work closely with labour struggles, socialist feminists were active in the 1980s to oppose the successive neo-liberal free trade agreements negotiated between Canada and the United States. Along with mobilizing work, socialist feminists highlighted the effects the trade agreements would have on women workers. Marjorie Cohen, co-chair of the Coalition Against Free Trade, explained what she and other like-minded people thought the women's movement and analysis could bring to the anti-free trade movement:

What I felt we could bring was what was going to happen to women's jobs and that was the whole services sector. [The men] were focused on automobiles and the manufacturing sector and I knew the manufacturing sector was important for women because they were going to lose everything in clothing, textiles, boots, shoes, and small electronics. But, what I thought our innovation was...was in bringing a discussion to the services sector. ${ }^{96}$

Canada and the US began negotiations on the Canada-United States Free Trade Agreement (CUSFTA) in May 1986, in 1987 a deal was reached between the governments and in 1988 the proposal "became the major Canadian election issue" (Wilkinson 2006: n.p). CUSFTA was seen by socialist feminists, as well as the broader left and trade union movement as an attempt to undercut workers and the gains they had made. The governments and media of both countries tried to sell "freer competition" as beneficial for the Canadian economy, while socialists insisted that any benefits would go to the capitalists, not the workers, giving capital the

\footnotetext{
${ }^{96}$ Cohen, interview with researcher, August 26, 2018.
} 
opportunity to move to areas with low unionization and lower or no minimum wage (Egan and Gordon 1988). Some predictions of the left and trade union movement have been borne out, with declines manufacturing employment and union members in Canada. Since the CUSFTA came into effect in 1989, union membership has declined from 36 per cent, to 29 per cent in 2014 (Statistics Canada 2018). Manufacturing employment has fallen from 2,145,900 persons in 1989 to 1,734,000 in 2019, despite a population increase of more than 10 million (Statistics Canada 2019).

In 1988, Rebel Girls' Rag ran an article entitled "No to Free Trade, Yes to Full Employment" which argued that free trade was "part of the reorganization of the world economy following the 1973 recession, it is one of a package of economic measures introduced by neo-conservative governments led by Thatcher, Reagan, Mulroney and others." The TSFA newsletter argued that the new push for free trade went "hand-in-hand" with the "privatization of social services, erosion of trade union rights and wages falling behind inflation" (Egan and Gordon 1988: 2). Socialist feminists well-understood that women and racialized workers were typically the hit the hardest when jobs disappeared or moved, and worked to highlight this fact within the broader movement (Egan and Gordon 1988: 2). The "garment, textile footwear, leather and electronics industries," where many immigrant and racialized women worked, were seen as particularly vulnerable (Coalition for Visible Minority Women 1987: 11). In a meeting with Progressive Conservative MP Barbara McDougall, then Minister responsible for the Status of Women (1988 to 1990), Alvarine Aldrige a factory worker at GH Sportswear Ltd., laid out these impacts, 
The clothing and textile industry is the second largest industrial employer in Canada, employing twelve percent of the manufacturing labour force (second only to the food industry). Of the 100,000 Canadian jobs, 79 percent are held by women. These are 80,000 Canadian women who work in clothing. This industry employs the highest percentage of women on any manufacturing sector. Approximately 80 percent of these women were not born in Canada (As quoted by Our Lives 1988: 11).

Socialist feminists advocated that they join "trade unions, immigrant women's groups and other organizations of the disadvantaged" to oppose the CUSFTA (Egan and Gordon 1988: 2). ${ }^{97}$ Women members of the OFL and Ontario New Democratic Party (ONDP) organized a "Women Against Free Trade" group, which organized pickets, community meetings, and press conferences to highlight the negative consequences of neo-liberal free trade for women and workers (OFL Women's Committee 1988). However, this campaign was seen by some to focus on electing the NDP as a progressive alternative, which some socialist feminists called into question (Stephen 1988: 4). NAC also made important interventions on free trade, and, as a result, "relations between NAC and the federal government became less cooperative and increasingly adversarial" (Bashevkin 1989: 366). NAC's analysis of the CUSFTA was based on the research by the socialist feminist scholar Marjorie Cohen and NAC vicepresident, who was also active in the Council of Canadians, the Pro-Canada Network, and the Coalition Against Free Trade (Bashevkin 1989: 366-367). Cohen's research was published by NAC and contributed to the organization's decision to join coalitions

\footnotetext{
97 They were right to warn about the potential job losses and attacks on workers. The garment and
} textile industry was shown to be less profitable in Canada as imports from the US flooded the market. 
comprised of organizations opposing the government of the Brian Mulroney Conservatives then the only political party supporting the CUSFTA. This led the “federal conservatives in the spring of 1989 to reduce NAC's funding by more than 50 percent...by 1992 and refuse to participate in the annual NAC lobby on Parliament Hill” (Bashevkin 1989: 368-369).

\subsection{Free and Universal Daycare}

During the 1970s, childcare became an issue around which feminists organized, and socialist feminists played an important role in connecting the demand for daycare with the broader class struggle and fight for socialist reforms. While Anne Fourth (1987) claimed the issue of universal access to childcare was relatively marginalized in Canada except for the activity done by socialist feminists (3), Susan Prentice (1986), a childcare activist, argued that the issue was mostly "the object of benign neglect by socialist feminists" (7). The truth seems to lie somewhere in the middle of these two claims. Socialist feminists were indeed fighting for access to childcare but their capacity to organize was limited by their focus on a wide range of issues. Campaigns for childcare were widespread in the 1970s and 1980s, far beyond the campaigns that exist today. Socialist feminists identified the lack of access to childcare as one caused by commodification and/or privatization, whereby parents were expected to "purchase [daycare] in the marketplace" (Betteridge 1986: 9). For socialist feminists, lack of access to childcare was therefore a systemic issue of the capitalist economy.

Childcare was further seen as both a public and private issue, bound up with expectations of womanhood and the nuclear family structure. Marianne Gilbert, a 
socialist feminist active in the Child Care Committee of the New Democratic Party Women's Committee put the issue in the following way, women are daycare workers...privately within the family and publicly within daycare centres...Feminist socialists will not accept the view that the family and the economy are separate independent realms. WE KNOW the family cannot be transformed except as part of the general transformation and destruction of capitalism (original emphasis, 1975: 19).

As Gilbert argued, the socialist feminist position emphasized that childcare needed to be re-imagined and transformed based on a new political economy. Childcare should be the responsibility of the whole of society, not the primary responsibility of mothers in individual family units. This was the argument put forth by many groups including Saskatchewan Working Women (1980) who argued that "good daycare" was "one of the fundamental needs of working women" and that "the inadequacies of the presentday care system" were "an immediate and central concern of all working women in the province" (1). Similarly, the Vancouver Women's Caucus (VWC) argued "that society - not just the mothers and the fathers - has the responsibility to provide for children, and that daycare should be available and free" (Briemberg 2019: n.p). Socialist feminists recognized that while the onus of child-rearing was put on individual women, the capitalist class benefited, and indeed relied on women to provide a new generation of workers that required no investment on their part. In other words, women had the de facto responsibility to continue to reproduce the labour force of capitalist society. Socialist feminists developed theory, research, and practice to support this idea. Furthermore, as the RMG said, "the position of women under contemporary capitalism" was "characterized by a fundamental contradiction" 
(1975: n.p). The "growth of the productive forces demands female labour outside the home" but "the capitalist relations of production precludes the socialization of domestic labour" (RMG 1975: n.p). Women, the RMG argued, "have been both allowed and forced to labour outside the home, while maintaining their role inside it, and this has produced their dual role as wage and domestic workers" (original emphasis, RMG 1975: n.p). In this light, socialist feminists saw the issue of childcare as central to the contradictions in capitalism and the relationship between the family structure and economy in capitalist society.

While socialist feminists saw the issue of childcare as one ultimately requiring revolutionary transformation, activists also made short-term demands for reforms. This primarily took the form of calling for the opening of more publicly-funded daycare centres, a demand made as early as the 1960s. At the University of Toronto, student activists, many who would later identify as socialist feminists, occupied a campus building for 8 months demanding that the university provide childcare for students and faculty. For many, the experience was transformative and went far beyond the demands for childcare. Luxton (2018) explains:

[The occupied building] became a place where political activists on campus could meet each other. We occupied it for 7 or 8 months and a lot of that time was spent sitting on the floor watching kids play or fall asleep and talking. It was like a political education residential school for New Lefties...For me, the daycare was simultaneously an educational project. We read, studied, and talked to each other about the way you might in school but we were also raising our kids together...I'm loving living with all these other people...That 
gave me a practical experience that was very precious...We were initially going to raise the socialist baby and make revolution. ${ }^{98}$

The activists ran the occupied daycare "as a parent coop." ${ }^{99}$ After 8 months of occupation, the University of Toronto agreed to the protesters' demands and the daycare centre is still active today.

A similar fight for childcare took place at Simon Fraser University led by Melody Kilian. Students and faculty occupied a Board of Governor's meeting in Spring of 1968 to protest a Canadian Association of University Teachers (CAUT) censure. They brought their children with them "somewhat satirically to use the space to fill a student need" and from that occupation emerged the idea of an on-campus nursery (Kilian 1968: 4). Shortly thereafter, students occupied space on campus to form an independent nursery. The experience, Kilian argues, led the participants to rethink what it meant to raise children as a communal family. The grassroots nursery did not last. Indeed, by their own self-admission, VWC did not fully commit itself to the issue of childcare and instead other issues like "organizing working women, educating women about women's oppression, and the abortion campaign took precedence" (Briember 2019: n.p). However, VWC continued to fight for childcare by aiding in the organizing efforts of women's unions such as the Service, Office, and Retail Workers Union of Canada (SORWUC) and the Association of University and College Employees (AUCE). Childcare became a central demand for union negotiations and "two daycare centres were organized into SORWUC" (Briemberg 2019: n.p).

\footnotetext{
98 Luxton, interview with author, July 19, 2018.

99 Petersen, interview with author, August 31, 2018.
} 
It was not until 1979 that the childcare movement in Ontario decided "to move onto the political offensive and adopt the slogan of universal daycare" (Fourt 1987: 3). Action Daycare, founded in 1979, was one of the first organizations to take up this call. Fourt (1987) argues, "up to this point the strategy had been mainly defensive in nature, fighting to keep daycare centres open one by one" (3). Socialist feminists of IWDC partnered with Action Daycare, which advocated for universal service funded by the "Ministry of Education rather than Social Services" under the belief that "childcare should be a right not a welfare program" (Action Daycare 1982a: 2). Action Daycare began as a provincial advocacy group but "expanded its mandate into the federal arena" in the 1980s (Rise Up! Feminist Archive 2018c: n.p). Action Daycare activist and socialist feminist Pat Schulz cited France, Sweden and Cuba as examples of countries that took an acceptable approach to childcare (Briskin and Weir 1981). The organization argued that two events in Canadian history showed that universal childcare could be easily implemented. In 1930, "the ten month publicly funded school year was created by legislation for all children over seven years of age" (Action Daycare n.d, n.p). During the Second World War, the federal government passed an Order-in-Council authorizing the Ministry of Labour to enter into cost-sharing agreements with any provincial government willing to establish daycare services," resulting in the fast establishment of public childcare (Action Daycare 1982b: 16). Action Daycare pointed out that when the war broke out, "overnight the image of the perfect Canadian woman changed from being the foundation of hearth and home to being the industrious beauty on the assembly line," and thus, the state had to “consider alternative care for children" (Action Daycare 1982b: 16). These examples 
demonstrated that the problem was not the unfeasibility of public, universal childcare. Instead, the main obstacle identified by socialist feminists was government priorities and government subservience to free market and profit driven daycare. There was also a patriarchal element to childcare in which women were seen as natural caregivers who should provide for their children. In 1981, "the daycare movement developed a platform which was adopted...by the NDP and then by the OFL in 1981" (Fourt 1987: 3). This movement continued throughout the rest of Canada and in 1982, "a conference in Winnipeg led to the development of a national organization, the Canadian Daycare Advocacy Association" (Fourt 1987: 3).

The second immediate demand by socialist feminists was that workers in daycare centres should be unionized, with acceptable wages and working conditions, including staff training, a reasonable child-adult ratio, and suitable physical space (Action Daycare 1982a). In this analysis, the problem of lack of access to daycare was compounded by the frequently low-wage, insecure, ununionized nature of existing childcare positions. As well, every effort was made by employers to undercut those daycare workers that did occupy unionized positions. When daycare workers did go on strike, as was the case for Mini Skool workers in Ontario (1982), socialist feminists joined them on the picket line. As was their usual approach, socialist feminists organized on the principle that the only way to win access to childcare was by bringing together women, workers, mothers, and allies together in one struggle. As Betteridge (1986) argued, "the current crisis is unlikely to be solved unless a wide variety of organizations join daycare lobby groups to demand free universal daycare" (9). 
When such demands were ignored or dismissed by governments, some socialist feminists joined with others to open non-profit daycares. Some debate emerged around the politics of this strategy, as many saw it as not feasible as a longterm strategy or demand, but a short-term way of fulfilling an existing need. Socialist feminists Adamson and Prentice (1985) argued that, while they knew that establishing non-profit daycares would not "result in the free universal daycare system which was our ultimate goal, ...we knew we needed to organize to provide our own care in the interim" (6). ${ }^{100}$ They continued,

Before we get to where we are going, we need the tools to help us move. We are all aware of the true 'slippery slope' of 'accepting liberal reforms in place of radical social change.' Nevertheless, those co-op daycare centres housed some of the most vigorous and vocal daycare activists, who, while holding onto a longer-term vision, nevertheless chose to establish care in their own neighborhoods. Our provision of care for ourselves and our kids, while still focussed on demanding services from the state, was a radical act (Adamson and Prentice 1985: 6).

Debates over the establishment of non-profit daycares demonstrated the constant tension within socialist feminist politics about how to deal with the immediate needs of women, without sacrificing their transformative socialist politics. ${ }^{101}$

\footnotetext{
100 These efforts stimulated huge growth in community co-op daycares across Canada - including by people who were not affiliated with socialist feminists. Many of these centres are still in existence, run collectively by parents and communities, but not under any political banner.

101 The same thing can be said for the struggle against violence against women, of which socialist feminists were also a part, though not to the same extent as radical feminists. These activists, for example, established rape crisis centres to deal with the immediate problems faced by women, but were still uncompromising in their mission to end the structural and interpersonal relations that led to violence against women.
} 


\subsection{Positions on Wages for Housework Campaign}

During the height of socialist feminist activism in the 1970s, another campaign - spearheaded by autonomist Marxist feminists - sought compensation for women working as housewives. In 1972, Selma James, Mariarosa Dalla Costa, Silvia Federici, and Brigitt Galtier co-founded the International Wages for Housework Campaign, which "organized around the principle that women should be paid for performing the socially necessary labour of housework and childcare" (Rise Up! Feminist Archive 2019: n.p). The movement came out of the Italian radical autonomist tradition and its activists helped to shape early social reproduction theory (Huot 2016; Rousseau 2016). In 1973, Dalla Costa and Federici toured Canada to promote the campaign. Their speaking tour was well-received by some activists, particularly those in an organization called New Tendency (Huot 2016). New Tendency (1973-1975) was composed largely of student activists influenced by autonomism and who were critical of Marxist-Leninists and Trotskyists (Huot 2016). In 1975, these activists would go on to establish the Toronto Wages for Housework Committee and, soon thereafter, committees in several other cities including Regina, Kitchener, Winnipeg, and Ottawa (Huot 2016; Wages for Housework Committee 1977b).102

Wages for Housework activists saw the housewife as a proletarian, regardless of her husband's class position. Giuliana Pompei (1972) argued, "No one has even thought that a slave was not a slave if he had a rich master who could guarantee him a higher standard of living than other slaves" (2). If women were going to achieve

\footnotetext{
102 New Tendency eventually split because Wages for Housewife activists wanted their campaign to take priority over the other issues the group was focusing on.
} 
equality with men, Wages for Housework activists argued, they needed to be paid for their work in the private sphere (Wages for Housework Committee 1977, 1977b). They also advocated for demands beyond compensation for their work in the home. Some of these demands included free abortion on demand, increased wages for women, the decriminalization and destigmatization of prostitution, and custody for lesbian mothers (Wages for Housework Committee 1977, 1977b). Furthermore, activists advocated for increased social services which would reduce their hours of work: "we want greenery, gardens and parks in every part of the city - which means not spending two or more hours a day taking the children out to breathe and play" (Pompei 1972: 5).

Wages for Housework organizers in Canada shared an understanding of women's oppression in the home with socialist feminists. Both groups understood women's oppression as stemming from patriarchy and capitalism. While Wages for Housework activists subscribed to a socialist feminist theory of social reproduction, there was a perception among some socialist feminists that the Wages for Housework campaign held different values and priorities to the socialist feminist movement. Debbie Field remembered Wages for Housework activists to be "radical feminists" and argued that socialist feminists were opposed to their campaign. ${ }^{103}$ Furthermore, she recalled serious tensions between the two groups because of her and other socialist feminists' participation in mixed-gender organizations like the Revolutionary Marxist Group:

${ }^{103}$ Field, interview with author, November 8, 2018. 
There was a group of radical feminists, particularly around Wages for Housework, who were very hostile to us. They just really thought that any women who hung around with men, in a mixed organization, were not really good feminists. ${ }^{104}$

The objection towards Wages for Housework is echoed in Luxton's More Than a Labour of Love. Luxton (1980) shares the concerns of housewives in Flin Flon, Manitoba who worried that wages for housework could put women under further control of the state and their husbands. For one, they argued that women could be easily manipulated in and out of the workforce depending on the size of the government's child support payments (223-224). Furthermore, they worried that their work in the home might be regulated and supervised (223-224). Luxton concludes,

very few groups have actually campaigned specifically for housewives, and therefore the women involved in the wages-for-housework campaign deserve credit. However, their campaign is essentially a dead-end one, which will not eliminate the contradictions of domestic labour and which may well divert women's energies away from more useful strategies (224).

Similarly, Liz Rowley remembered socialist and communist women opposing Wages for Housework. She recalled the Communist Party's "strong position" that housework "was not work that we thought women should be paid for."105 Instead, the CPC demanded changes to how household labour was done throughout society. They pointed to "developments in the Soviet Union where childcare was available

\footnotetext{
${ }^{104}$ Field, interview with author, November 8, 2018.

105 Rowley, interview with author, January 4, 2019.
} 
everywhere in factories and workplaces," where there "were community kitchens where people could go to eat" so that "they didn't have to go home [from work] and do a second shift," and where there were "communal laundries" and other "efforts to socialize those household tasks that have traditionally fallen to women."106 In the US, Angela Davis (1982) also wrote a critique of Wages for Housework, arguing that the movement:

assumes that if women were paid for being housewives, they would accordingly enjoy a higher social status. Quite a different story is told by the age-old struggles of the paid household worker, whose condition is more miserable than any other group of workers under capitalism (136).

Wages for Housework activists acknowledged, "wages for shit work is still shit work" (Pompei 1972: 5). The primary solution they presented, however, was "to reject our role" by "not getting married and not having children" (Pompei 1972: 5).107 Yet, Wages for Housework located women's power in the idea of the welfare mother:

Our biggest source of power as women is precisely the welfare mother who put a price tag on raising a family and won us our first wage for housework. The very fact that some women have a wage for that work automatically puts more leverage in the hands of all women (Wages for Housework Committee 1977: 3).

This is a radically different perspective from those socialists who saw women's political power rooted in their unions, parties, and organizations. Davis (1982) also critiqued the whiteness of Wages for Housework, arguing that black women had long

\footnotetext{
106 Rowley, interview with author, January 4, 2019.

107 This is exactly the position that Morton (1972) criticized Benston (1969) for arriving at (see Chapter 1).
} 
been paid for domestic labour and yet it did not alleviate their oppression. She argued, "As paid housekeepers, [black women] have been called upon to be surrogate wives and mothers in millions of white homes" (Davis 1982: 136). She further argued that the campaign had the adverse effect of discouraging women from entering the labour force.

Nonetheless, socialist feminists, communist women, and Wages for Housework activists largely shared an analysis that women's unpaid labour in the household was essential to their oppression. Some went further, arguing that this unpaid work was essential to the functioning of capitalist society. As discussed in Chapter 1, the idea that women's oppression is tied to their unpaid work and role in the family was central to Margaret Benston and Peggy Morton's analysis. Where activists differed was in how to organize around this observation and what role capitalism played. Socialist feminists, communist women, and Wages for Housework activists experienced frustration with the way that their issues and concerns were ignored in other leftist organizations, and by Marxist theory which they saw as excluding analysis of women's unpaid work in the home. Giuliana Pompei's Wages for Housework outlined this frustration:

When we began looking at ourselves, as women, one of the main things we discovered was that the home, the family structure as a place of specific exploitation of our labour power. In our analysis we must perforce give first place to this 'private sphere,' these domestic walls outside which Marxist class analysis - not to mention the practical activity of the left political organizations and out of parliament - stops. Inside the home we have discovered our invisible work, the enormous quantity of work that women are forced to perform every day in order to produce and reproduce the labour force, the 
invisible - because unpaid - foundation upon which the whole pyramid of capitalist accumulation rests (1972: 1).

Wages for Housework lost momentum at the end of the decade.

A major pitfall of the Wages for Housework campaign is that it was premised on the continued isolation of women in the home where political organization and unionization is difficult. In this respect, socialist feminists, radical, and autonomous Marxists all agreed on the family (private sphere) as the primary location where women are oppressed. Kilian (1968) paints a picture of this isolation and oppression in practice:

So often I see pregnant girls at work and I'm horrified at their innocence of their own fates. Their expectations are so high and so happy. The other girls give the young mother a baby shower, the beginning of her new consumer role. When she finally leaves they send cards. She might visit her old work place once or twice to show off her baby. At first it probably feels good to be away from a job that was probably low-paid and dreary anyway. But then somehow everyone forgets about her. Very soon she finds herself cut off from the outside world. Lonely and bored in her apartment with her baby, she senses that the rest of the world is going on without her. She begins to wonder why it is that she is not happy...Sometimes she stands beside the crib and watches her sleeping baby and is almost overcome by love for him or her. She would not give up her baby for anything. But why then is the love clouded by doubt and guilt? Why does she also spend so much time standing at the window waiting for something? What is wrong with her that she sometimes secretly wishes she had never had the baby? Perhaps she is not maternal enough. Maybe she is sick because she doesn't love her own baby...The doctor might prescribe some tranquillizers (1). 
Wages for Housework does not change the position of women in society, nor does it reflect the reality of growing numbers of women who work full-time. It does not change women's relationship to housework or gender roles more broadly. Present day liberal feminist variations on this objective, such as the Canada Child Benefit, 108 do not provide sufficient support of the kind Wages for Housework demanded, but are not far off the aims of the campaign.

\section{Conclusion}

Socialist feminists attempted to connect the experiences and struggles of working-class women with an economic and structural analysis of capitalism. In doing so, they were able to push the women's movement to consider the role that capitalism played in women's oppression, and to make radical economic demands. Socialist feminist involvement in struggles around maternity leave, abortion, and in the labour movement contributed to a number of important gains. Despite some gains, these struggles are still relevant today, and activists can still learn from these struggles. In other words, socialist feminism did not exhaust its raison d'être. In particular, activists should understand why women's liberation requires economic transformation. The quality of working-class women's lives and the choices available to them depend on how resources are allocated, and who is empowered and prioritized.

\footnotetext{
108 Introduced in 2016, the Canada Child Benefit program is a monthly payment given by the Canadian federal government to those eligible with a child or children under the age of 18 . The payment averages around $\$ 500$ per month per child, with additional benefits decreasing with each child up to 4 , if the family net income is over $\$ 31,120$ (Canada Revenue Agency 2019).
} 
The struggle for socialism, a prerequisite of women's liberation, necessarily includes proletarian internationalism. Socialist feminists made connections with women across the world who were struggling against oppression, imperialism, and war. They also spoke out against Canada's negative role in many international conflicts. Both of these are important and notably diminished in today's women's movement. While socialist feminist expressions of solidarity with immigrant, racialized, and "third world" women didn't go far enough, they demonstrate a desire to do better. Their political theory and their actions could have been strengthened had they made earlier connections between the issues they advocated for and the specific ways that working-class immigrant, Indigenous and racialized women experienced them (e.g. abortion/forced sterilization).

Socialist feminists began to form their own autonomous women's groups because they felt that their issues were not being addressed in a satisfactory manner by existing Leftist organizations. In these autonomous groups, it was possible for socialist feminists to prioritize analysis of so-called women's issues and work on campaigns directed at women's economic independence, health, and well-being. While socialist feminists sometimes had the support of their other/former organizations, their decision to form separate groups made them a small, albeit important, force. Their small numbers also required them to participate in coalitions with other women who did not always share their political analysis. Socialist feminists made coalitions with activists across political and class differences on issues of daycare, abortion, anti-war, labour, and against racism. Indeed, some socialist feminists went so far as to suggest that it was through these coalitions that 
revolutionary change that centered women would occur. While these coalitions were helpful to pushing forward certain demands, they were also mired in debate as political tendencies clashed. Thus, attempts at autonomous organizing and coalitionbuilding had mixed results. In the final chapter I analyze these and other organizational issues that socialist feminists encountered. 


\section{Chapter 5: Conclusion}

This concluding chapter focuses explicitly on the organizational practices and strategies of socialist feminists by drawing on interviews and archival research. I review some of the divergent perspectives within and around socialist feminism about questions of aims and organization. In particular, I look at the debates around hierarchy, leadership, and involvement in the NDP. Some of the questions I sought to answer were: Did Canadian socialist feminists see structurelessness, consensus, and leadership as important and why/why not? What debates emerged around these methods? How did anti-hierarchy play out in practice? What issues arose around structurelessness? How did socialist feminist coalition politics differ from the Old Left approach to coalitions? Why did socialist feminists organize in the NDP when their politics were more revolutionary in outlook? What lessons can we gather from experiments with New Left forms of organizing? Most significantly, I examine the efforts to define a socialist feminist politics around particular organizational practices.

\subsection{Understanding Unity and Political Divisions}

As I have already demonstrated, no clear consensus on political strategy existed within the socialist feminist movement. This was the criticism made by Brock and Wright (1988) in their review of the 1988 book Feminist Organizing for Change, which attempted to crystallize a socialist feminist politics for the time based on their experiences in Toronto. Brock and Wright argued that the authors, Adamson, Briskin, and McPhail "write as if ... [there is a] unified vision of socialist feminism where there is virtually none in place" (1988: 4). For many in the movement, socialist feminism 
was never a coherent political and ideological movement. Therefore, in developing an analysis of socialist feminist strategy it is important not to characterize the movement as homogenous. This is further complicated because early socialist feminists were reluctant to disagree with one another and argue out differences. As I demonstrated in Chapter 4, emphasis was placed instead on unity and working together on campaigns and political goals. It is, however, possible to talk about some of the similarities and differences within the movement.

\subsection{Structurelessness, Consensus, and Leadership}

Many self-identified socialist feminists in Canada organized in Trotskyist groups and in the New Democratic Party, both of which adhered to traditional forms of party organization, leadership, and decision making. However, within IWDC, TSFA, the Vancouver Women's Caucus, and other distinctly socialist feminist groupings ${ }^{109}$ women embraced other forms of organizing centered around principles of structurelessness, consensus, and eschewing formal leadership. Some socialist feminists with experience in traditional left parties and organizations turned their backs on traditional forms of organization that they saw as contributing to their marginalization. Instead, these activists took inspiration from the larger feminist movement, which was then experimenting with anarchist-inspired, horizontal forms of organizing. Luxton (2001) argues, "strategically, socialist feminism aimed to enable and to empower women to act on their own behalf politically, rather than relying on leaders" (86). Commenting on socialist feminist organizing in the U.S., Burnham and

\footnotetext{
109 The same is true within the women's movement more broadly. This includes groups that were not distinctly socialist feminists but in which socialist feminists played a large role (like the Toronto Feminist Bookstore).
} 
Louie (1985) explain, "the rejection of both the traditional socialist movement and the 'establishment' was extended to a rejection of traditional forms of organizing. As such, political strategy became tainted as an expression of socialist 'orthodoxy' or a 'male hierarchical' approach and was consequently dismissed out of hand" (97). This was sometimes the case in Canada as well. Some socialist feminists even saw "the dissolution of Trotskyist and Maoist parties during the late 1970s and early 1980s" as having "beneficial effects on socialist feminist open meetings" because this allowed local feminists to get together on more amicable and less sectarian terms (Weir 1987: 102). The destruction of the "traditional left" therefore could be seen as an opening for organizing, rather than a defeat or harbinger of their own decline. Today, much of the British and American socialist feminist literature continues to ascribe to a decentralized politic (Brenner 2014; Wainwright 2015).

My interviews with research participants and a survey of archival documents indicate that socialist feminists in Canada tried their best to organize in ways that weren't so top-down and experimented with what could be accomplished using new organizational methods. Take, for example, Carolyn Egan's recollection of organizing in OCAC and IWDC:

We [OCAC] tried to work in that way [prefigurative and non-hierarchical]. We had meetings once every two weeks that were open to everyone as long as they supported the goals we were moving towards. We did have an elected coordinating committee but all our decisions were made at the larger meetings and we tried to be - nothing is ever perfect obviously - but we tried to build as inclusive and democratic movement as possible so that it turned on the head [the idea] that there were leaders, the leaders would make 
the decisions, and the leaders would guide the movement...In IWDC it was pretty much the same style of organizing. ${ }^{110}$

Similarly, Linda Kealey spoke about the importance of anti-hierarchy. For her, and others in the movement, anti-hierarchy was a way of rejecting traditional organizational models whereby men dominated as leaders:

We talked about not having leaders and trying to take turns at leading discussions or doing jobs. Non-hierarchy was one of the aims of [socialist feminism]. Rejecting male models [of organizing] but, of course, that only works if people are fairly like-minded and not basing any of their personal worth or sense of themselves on leadership... So, it's limited, but I think it was a useful phase of trying to think about power and how power works. ${ }^{111}$

Marjorie Cohen also remembered decentralized forms of organizing as being important to socialist feminists and other New Left organizers: "[Prefiguration and non-hierarchy] was an objective of socialist feminists but I don't think it was exclusively socialist feminist." 112 While these organizational forms were widely embraced and considered innovative at the time, many socialist feminists later came to reflect on their strengths and weaknesses. Some continued to ascribe to a prefigurative and non-hierarchical politic; others felt it was a strategy suitable for some organizations and campaigns but not useful for others; and some came to outright reject it. 113

\footnotetext{
110 Egan, interview with author, October 1, 2018.

111 Kealey, interview with author, August 13, 2018.

112 Cohen, interview with researcher, August 26, 2018.

113 In Chapter 4, I showed how Petersen was frustrated with daycare activists and organizers who insisted that she see their perspective so that they could follow consensus. Her experience organizing with the Young Socialist Alliance, Revolutionary Marxist Group, and Revolutionary Workers' League led her to reject consensus. Similarly, Rebick, who also organized in the RMG and RWL, argued that at
} 
Some of the biggest debates around consensus and hierarchy emerged from the IWDC and, later, TSFA. These organizations, from their inception, tried to work on the principles of consensus and anti-hierarchy. They were fairly successful in this respect as smaller organizations that did not try to expand outside of the Toronto area. Even still, they came up against problems of organization that are typical in groups following such principles. Within IWDC, some became frustrated with the refusal of the organization to acknowledge the existence of leadership in its ranks. Former IWDC member Sandy Steinecker (1984) argued this point after her resignation from the group, writing,

There was an article published - "the Tyranny of Structurelessness" - that I remember really hit home to me at that time. I started to think that the concept of leaderlessness or structurelessness was part of what was going wrong.

In fact, neither IWDC nor the coalitions we initiated were leaderless or structureless. Instead, we created informal structures which were worse, and harder for new women to get into because they weren't formal or acknowledged. The result was a fairly complicated series of cliques and hierarchies that were never acknowledged because you weren't supposed to have them. And so, to try and penetrate that was almost impossible because it wasn't there; it was like the emperor having no clothes - you couldn't get at it. I remember thinking that the organization was screwy...

I would like somebody to say, you know what, maybe the women's movement does need some leaders. Even better, to admit that the women's movement has leaders. Because it does. There is no question. I have a list of people and if

the time her Trotskyist training led her to view the political party as playing an important role in revolutionary change. 
somebody came into town and said to me who are the key women in Toronto, I would know who to tell them to call (14-15).

This phenomenon was observed not only in socialist feminist organizations but within the broader feminist movement, where it faced its own critiques.114 In the article to which Steinecker referred, "The Tyranny of Structurelessness," Jo Freeman (1970) argued that the idea of structurelessness arose out of a real concern for the way that leadership, especially male leadership, gave control to "others over our lives" (1). ${ }^{115}$ Freeman's paper argued that, as a result of this experience, the idea of structurelessness became "an intrinsic and unquestioned part of women's liberation ideology" (1). This organizational approach appeared to work in consciousness raising groups, but "without realizing the limitations of its uses" many feminist activists applied it elsewhere "out of the blind belief that no other means could possibly be anything but oppressive" (2). At its inception the idea of structureless or non-hierarchical organization in the feminist movement likely appeared as a logical mechanism to address very real barriers women faced within organizations. Instead, as Freeman argued, structurelessness could spontaneously reproduce hierarchical leadership structures in informal ways. Freeman made the case that this phenomenon took place through friendships, networks, and connections outside a given political group becoming the basis of new informal structures within the group. When this happened, women would "become informal, unplanned, unselected,

\footnotetext{
114 Namely, as Freeman (1970) points out, the critique that leadership (and therefore hierarchy) was present and acted to subdue the voices of some members.

115 I highlighted the way this manifested in the previous chapter, with regards to Bernstein, Morton, Seese, and Wood's criticism of SUPA, the New Left, and participatory democracy.
} 
unresponsible elites; whether they intend[ed] to be so or not" (Freeman 1970: 8). The danger of structurelessness, Freeman argued, is that decisions will be based on friendships over actual ideas and that "informal structures have no obligation to be responsible to the group at large. Their power was not given to them; it cannot be taken away" (6). ${ }^{116}$ In other words, with formal structure, hierarchy and organization, come the possibility for accountability and mechanisms to enforce it.

Freeman (1970) further argued that, if the women's liberation movement was "to move beyond...elementary stages of development," it needed to abandon structurelessness as an organizational principle. She noted, "we cannot decide whether to have a structured or structureless group; only whether or not to have a formally structured one" (1970: 3). Furthermore, Freeman argued, structureless groups can only work at a local level, while the women's movement needed to organize nationally. This inability to organize on a larger scale, as well as to move forward politically, was Steinecker's second criticism of IWDC: with no formal leadership structure or organizational strategy, some felt the group was instead too focused on working to bring new members up to speed politically. Steinecker (1984) explains,

I remember talking to a friend about our experiences in IWDC. We were both feeling really frustrated that we couldn't move forward; we felt on this treadmill, always working with where the newest women were. I don't mean that in a disparaging way, even a little. But what always happened is that they

\footnotetext{
116 "This does not mean that we should go to the other extreme and blindly imitate the traditional forms of organisation. But neither should we blindly reject them all. Some traditional techniques will prove useful, albeit not perfect; some will give us insights into what we should not do to obtain certain ends with minimal costs to the individuals in the movement. Mostly, we will have to experiment with different kinds of structuring and develop a variety of techniques to use for different situations" (Freeman 1970: 10).
} 
came in with a certain kind of experience and a certain kind of knowledge and that's where we always had to deal, over and over again. We couldn't seem to use what we had learned over the years and give that to them. In fact, there was a real taboo against it. There was a taboo against having experience or using experience...

What we had in IWDC was like turning on a tape recorder; it just kept repeating itself over and over again. It felt like you couldn't move, you couldn't learn anything, that you were doomed to stay on the same conveyer belt over and over again. And it was really hard because any time you said something somebody turned around and using one word or another called you an elitist and thought you were trying to grab leadership or that you wanted to ignore new women, that you didn't care about integrating them (15).

In this way, IWDC operated more as a consciousness-raising group than a political organization drawing upon its experience to mobilize for militant struggle. In other words, the group began from the lowest-common denominator, with the goal of raising the consciousness of new members around a common politics, without a clear strategy for what was to come next for IWDC. Some, like Freeman and Steinecker, argued that this strategy was not sustainable for a political organization seeking to challenge capitalist relations of production or capitalists' political power. A similar concern was brought up at the Socialist Feminist Conference in 1987 where, "one woman remarked from the floor that absolutely no place had been provided for the consideration of socialist state formation, either actually existing or potentially so" (Weir 1987: 100).

Steinecker (1984) suggested that the IWDC should draft a constitution with their "analysis of the patriarchy, the role of capitalism" and how they believed "the 
system will be overthrown" and what their "role could be in the overthrow of that system" (15). She sympathized with "traditional left organizations" who had more clearly-defined responsibilities and who were "committed to working together over a long period of time (15-16). But, as Luxton (2001) explains, women's liberation groups were often, "less concerned about developing enduring organizations and institutional forms" and instead "relied on informal networks between individuals and small groups" to "set up collectives to provide services to women and strengthen the public face of the women's liberation movement" (85). The socialist feminist trend often shared these goals and strategies and they were effective strategies in one's local community. For many, socialist feminists' organizing priority was to "prefigure new liberatory ways of organizing society" (Luxton 2001: 85; Egan 1987; McKay 2005; Brenner 2014; Gordon 2013).

After five years of work with IWDC, Nancy Adamson (1984) resigned with similar complaints to those of Steinecker:

I finally decided to leave IWDC because I do not feel that we are going anywhere. I no longer know why we exist as a political grouping and it seems impossible to get the group to discuss that...I no longer believe the group can or will deal with the issues of politics, leadership, purpose, and accountability (2).

Adamson likewise argued that the organization failed to deal with questions of leadership and accountability. She levelled similar critiques against radical feminists in NAC. In 1988, Lorraine Greaves withdrew her candidacy for President at NAC's Annual General Meeting. A radical feminist who organized in the Violence Against Women Movement, Greaves argued that women in NAC's Left Caucus were abusing 
Robert's Rules of Order and interfering with the establishment of a genuine 'feminist process' (Chappell 2002; Adamson and Molgat 1988). She criticized NAC for always relying on voting "as the method to solve conflicts" (Chappell 2002: 42). Radical feminists in NAC saw "structure and organizational rules" as "inherently patriarchal and hence unsuitable for use by feminists" (Adamson and Molgat 1988). Socialist feminists Adamson and Anne Molgat (1988) wrote a statement dismissing the accusation that the Left was "somehow responsible for the difficulties" NAC was facing and accused Lorraine of "red baiting" (5-6). Further, they argued that the idea that there was some kind of agreed upon 'feminist process' was inherently flawed:

The suggestion seems to be that there is some process which will include all women, validate their skills and teach them new ones, and empower them, AND that all feminists, regardless of their political analysis, will agree on it. We feel that a focus on process obscures the debate which we would argue is actually about differing political analyses and hence differing strategies (6).

Their statement was published in Cayenne, "a socialist feminist bulletin produced by a group of women who were formerly part of the IWDC," but who left "because of a perceived lack of space for political discussion and debate within IWDC" (Rise Up Archive n.d). Thus, Adamson found similarities between radical feminist views of organization and socialist feminists within the IWDC.

For their part, TSFA (formerly IWDC) members Miriam Jones and Jennifer Stephen wrote a statement arguing that NAC's Left Caucus had been wrongly "scapegoated by a silent minority at NAC, called everything from male controlled to male influenced, and considered completely organized and disciplined" (5). Jones 
and Stephen stressed the importance of coalition politics to keep NAC going. They proclaimed that "unity or unanimity in our analyses" was neither desirable nor necessary, because "some common positions are arrived at on specific issues through the use of a coalition model" (5). They argued that calling for a kind of apolitical feminist process, radical feminists viewed coalition politics as a threat (Jones and Stephen 1988: 5). Radical feminists, Jones and Stephen (1988) argued, saw difference as un-feminist, while coalition politics encouraged discussion and acknowledged political differences. They also pointed out that it was women from the IWDC and OCAC who originally called for the organizational restructuring of NAC (Jones and Stephen 1988).

From this we can see that both within the socialist feminist movement, and between socialist and radical feminism, debate took place around questions of organizational methods, including voting versus consensus and other practices. In NAC, a major voice of the women's movement in Canada, socialist feminists rejected notions of an inherently feminist process. Despite this history of debate, recent efforts have been made to define a socialist feminist politics centred on such concepts, and to paint other forms of organizing as anti-feminist, "masculinist," and patriarchal. Such traditional organizational forms and practices have been called "barriers to women's self-development and leadership" (Brenner 2014: 39). For Brenner, socialist feminism is defined in part by its "commitment to self-organization" and structures "that are non-hierarchical and democratic and therefore more inclusive" (2014: 45). For Gordon (2013), socialist feminism is "closely connected to the principle of prefigurative politics - the notion that a democratic end goal cannot 
justify undemocratic means, because the end would be corrupted by undemocratic means" (n.p). While this may reflect the views of a distinct tendency in socialist feminism - perhaps the triumphant one - it was not the position of many in the socialist feminist movement and does not fully capture the historical circumstances from which it emerged.

\subsection{Coalition Politics and Social Democracy}

Throughout this dissertation, I have suggested that a distinguishing feature of socialist feminist activism was a prioritizing of coalition politics. Broadly speaking, coalition politics refers to the belief that political change will be brought about most effectively through uniting disparate organizations or stakeholders around a common goal. This idea was brought up in almost all of my interviews. Here are some examples from Rebick, Gottlieb, and Petersen:

You have to work with people you don't agree with. We learned how to build coalitions and how to negotiate differences...NAC itself was a coalition, the women's movement was a coalition, the free trade coalition, the anti-war coalition...It's not that we didn't have fierce debates because we did. But we didn't write off other people because we didn't agree with them. We worked with them. ${ }^{117}$

In order to be able to include and address different aspects of women's oppression we needed to bring together people who were involved in different locations, different campaigns, and issues, and bring them together so that we could: number 1 , have a better understanding of what was going on; number 2 , so that we could include those understandings and; number 3 , figure out a

${ }^{117}$ Rebick, interview with researcher, August 6, 2018. 
way to work together. If we didn't figure out a way to work together then our movement would be that much weaker. It was a way of strengthening our movement so that it included all the different locations of women's oppression, all the different ways women experienced that oppression, and the demands and campaigns that we were involved in as women. ${ }^{118}$

All of us are many things, so coalitions need to be built and that comes again, to me, from traditional Marxism and what a united front is. It's like what NAC was. It brought together under one umbrella...thousands and thousands of people who could come together...to fight for some basic issues. ${ }^{119}$

In many ways, this desire to form and work in coalitions is what made socialist feminists so successful in their ability to organize across different groups in the women's movement. To revisit some of their accomplishments, socialist feminists created a vibrant movement in Toronto and Vancouver and energetic organizations in other parts of the country revived the tradition of International Women's Day, formed important alliances with labour, and mobilized effectively for reproductive rights.

The socialist feminist preference for coalition politics can be seen as distinct from the early $20^{\text {th }}$ century leftist party attitude towards coalitions. ${ }^{120}$ The distinction is one of emphasis and approach, with New Left coalition politics valuing coalitions' significance as vehicles for change. For Petersen, her understanding of the

\footnotetext{
118 Gottlieb, interview with author, December 6, 2018.

119 Petersen, interview with author, August 31, 2018.

120 Rosa Luxemburg (2005) [1901]) once wrote about coalitions in France: "The first consequence of socialist participation in a coalition cabinet is, therefore, the renunciation of the most important task of all socialist activity and, above all, of parliamentary activity: the political education and clarification of the masses" (n.p). Similarly, Zetkin wrote that socialists must not collaborate with "bourgeois feminists' even on issues of common concern" (Boxer 2007:132). Eleanor Marx, Alexandra Kollontai, and Louise Saumoneau all expressed this animosity toward cross-class alliances (Boxer 2007: 137).
} 
importance of coalitions came from the Old Left and the idea of a united front, but, for many others, it came from the New Left. The Old Left did organize coalitions. For example, the $\mathrm{CPC}$ organized with the $\mathrm{CCF}$ or $\mathrm{CCF}$ members on various issues and based its party program from the early 1930s around the goal of a united front against fascism. In Russia, the early Bolshevik rule relied on a coalition with the left-wing bloc of the Socialist Revolutionary Party, and while the Bolsheviks saw themselves as representatives of the urban proletariat, they emphasized the need for a coalition with the poor peasantry. However, a distinction can be made between the socialist feminist vision of coalitions and that of the early $20^{\text {th }}$ century communists. Rather than the seemingly hegemonic view of coalition-building as one possible tool of the socialist movement towards a given end, many socialist feminists envisioned the development of the socialist movement "as the coming together of the many distinct and autonomous movements, each with a separate agenda reflecting the self-interest of the specific sector represented" (Burnham and Louie 1985: 114). Socialist feminists reasoned that, since women came from various backgrounds in terms of class (as well as race, sexuality, nationality) that this sort of coming together of women was necessary to an inclusive and powerful movement. Three such examples can be found in writings on the movement and one contemporary document:

In the women's movement, the theme of "unity in diversity" has replaced what is now considered an outdated and racist conception of "sisterhood." Focusing on differences among women has been a vehicle, not always successful, to promote solidarity among women across class divides, and across differences based on race, ethnicity, sexuality, ability, and political ideology (Briskin 1999: 22). 
While cautioning that there is no political consensus among socialist feminists she [Carolyn Egan] stressed that socialist feminism does offer a much broader conception of politics than traditional left models often permit. Socialist feminists are committed to actively building alliances between different political movements through a coalition and mass action strategy as well as extending the notion of politics both in terms of the relationship between political and personal life, and of process and methods of work within groups and movements (IWDC 1984: 12).

We believe that the present class system maintains and perpetuates racism, sexism and heterosexism, and must be overturned before these oppressions can be FINALLY eradicated...As socialist feminists we believe the concept of self-emancipation is fundamental...We take a mass action perspective. We build alliances with other oppressed groups in particular the organizations of the working-class. We recognize that...women's liberation and the emancipation of all oppressed and exploited people will only take place through collective [and] mass action...Our present political goal is to help build a mass movement of women with an anti-racist, class perspective, with the broad participation and leadership of working-class women and women of colour. We view coalition politics as a step toward this goal... (Rebel Girls' Rag 1988: 2).

The adherence to a new politic with emphasis on "unity in diversity," and "collective mass action" was a direct rejection of traditional left forms of struggle, in particular, the idea of "the struggle for a coherent general line" that could "guide the direction of the whole working-class movement" (Burnham and Louie 1985: 113). How deep this line of thought ran can be seen in socialist feminists' own insistence that there was "no political consensus" among them. Burnham and Louie (1985), in a contemporaneous polemic, characterized this perspective as one in which "there is 
no such thing as a politically identifiable and overriding class interest that could serve as a cohering thread, binding the elements of the progressive movement together" (113). They argued that that this outlook amounts to social democracy, rather than revolutionary socialism. Burnham and Louie summarize it as the belief that,

there is no political strategy capable of maturing the working-class movement into more than the sum of its disparate parts, each operating on the basis of its own independently developed agenda. In effect, it views the revolutionary formation as one grand patchwork of tactical alliances, and consigns progressive forces to eternally operating at the level of coalition politics (113).

They argue that this approach "holds out the gloomy promise of remaining at the lowest level common denominator politics and provides no inkling of how the left might progress towards a revolutionary program" (114). This mirrors Steinecker and Adamson's complaints expressed in their resignation from IWDC.

One significant reason behind feminists' and some socialist feminists' preference for coalition politics was their rejection of traditional vanguard or democratic centralist organizational forms espoused by the traditional left. Harriss (1989) argues that the women's liberation movement rejected "the hierarchical organization and vanguardist attitudes of Leninist groups" denying them "in favour of creating a broad-based movement operating in collective and collaborative ways. And above all [the women's liberation movement] asserted the need to organize autonomously around our oppression as women, to define our priorities without interference from men" (35). Since they relied on some degree of ideological, political and organizational agreement, these politics were often viewed as inherently incapable of inclusiveness. "Vanguardism" could be summarized as the idea that a 
highly-organized and determined section of the working-class movement must provide leadership and general direction to the broad working-class in order for the class to conquer political power. The idea can be traced to Marx and Engels' declaration in the Manifesto of the Communist Party that,

Communists, therefore, are on the one hand, practically, the most advanced and resolute section of the working-class parties of every country, that section which pushes forward all others; on the other hand, theoretically, they have over the great mass of the proletariat the advantage of clearly understanding the lines of march, the conditions, and the ultimate general results of the proletarian movement. The immediate aim of the Communists is the same as that of all other proletarian parties: Formation of the proletariat into a class, overthrow of the bourgeois supremacy, conquest of political power by the proletariat (Marx and Engels 1998 [1848]: 66).

During the height of the socialist feminist movement in Canada, organizations adhering to some version of the vanguard concept included the CPC, CPC(M-L), En Lutte, LSA, RMG, RWL and various smaller groups. While not precluding coalitionbuilding, "vanguardism" insists that some level of united organizational and political leadership must exist to build working-class consciousness and political power.

However, by the mid-1980s, much of socialist feminist politics congealed around the "unity in diversity" positions outlined above, many of which they shared with the broader feminist movement. While some disagreed with this explication of socialist feminism, others moved away from more traditional-left organizations and embraced them. The decline of what some called the New Communist Movement was seen as a kind of purging of sectarian forces that did not ascribe to, and even hindered mass action and coalition-building (Weir 1987). Further, some socialist feminists saw 
the rise of Trotskyist, Maoist, and Marxist-Leninist groups in the 1970s to have, ultimately, provided "a 'breeding ground' for socialist feminism" by providing a "context in which a politic that challenged that of the orthodox far left could develop" (Adamson et. al. 1988: 125). With the dissolution of many such groups, socialist feminism saw itself as a viable alternative to which activists could turn.

The more that socialist feminists rejected the traditional left and its positions, the more their politics began to resemble that of the radical feminists that they initially opposed. As the "socialist feminist movement began to lose some of its momentum and bearings...many Marxist women withdrew from socialist feminist organizations, if not from the women's movement altogether "(Vogel 1989: 1). Vogel (1989) explains,

The theoretical and organizational perspectives of radical feminism now appeared to offer more guidance to socialist feminists than they had before, particularly on the critical questions of sexuality, interpersonal relations, ideology, and the persistence of male domination throughout history. At the same time, women's experience in revolutionary movements and socialist countries seemed more removed from immediate socialist feminists' concerns. A certain pessimism regarding the achievements of existing socialist movements and the possibilities of current revolutionary initiatives developed. In this atmosphere, some socialist feminists became persuaded that Marxism could not be transformed or extended by means of the application of feminist insight but betrays women's liberation to the demands of socialism. Whereas socialist feminism has originated in a commitment to the simultaneous achievement of women's liberation and socialist revolution, that double commitment now threatened to break apart (1-2). 
Vogel here is speaking more about the movement in the United States, but a similar phenomenon could be observed in Canada. In particular, the rejection of vanguardism, democratic centralism, and the need for a general line become more apparent in socialist feminist literature both in academia and self-published zines and journals. This led many to embrace prefigurative, anti-hierarchical, and consensusbased forms of organizing. At the same time, many others turned to the NDP. Perhaps due to the decline of radical-left spaces, and the less stringent ideological requirements for membership, Canada's social-democratic New Democratic Party began to be viewed as a viable, if not the most viable, space for socialist feminist organizing.

\subsection{New Democratic Party}

Whether or not the NDP could be a vehicle for women's liberation was always a significant question in socialist feminist organizing. The debate comes up over and over again in socialist feminist zines, conferences, publications, organizations, and meetings. Jennifer Stephen (1988) summarized the dilemma in a contribution to Rebel Girls' Rag:

We have all asked at least once: 'What should we do about the NDP?' While many socialist feminists view social democracy with varying degrees of skepticism, the NDP is seen as a legitimate place for political work. What remains unclear, however, is how closely we should work with the NDP. Still others reject the party like a love relationship turned sour, the memory of which brings shudders, although not necessarily any sleepless nights (4).

The inability to decide whether to organize within the NDP is also a longstanding issue for the Trotskyist movement in Canada, from which many socialist feminists 
emerged. On the subject of orientation towards the NDP, the Trotskyist position also largely comes from its pessimism towards socialist countries and communist parties (Fourth International 1938). While the Marxist-Leninists and Maoists largely saw the NDP and social-democracy as an obstacle to revolutionary development, Trotskyists in Canada have more often seen it as an opportunity. The origins of this approach can be seen in Trotsky's proposal in the 1930s that his followers should enter social democratic parties, either to turn them towards a revolutionary socialist approach, or as a source of members for revolutionary organization (Fourth International 1938). Additionally, a reason that working inside the NDP may have been favoured by some is its relatively looser membership requirements, as the party does not impose significant ideological requirements on its members. This meant that socialists could join ranks with a mainstream political party and influence it from inside. Many held out hope that rank-and-file NDP members, and through them the party itself, could be won over to revolutionary socialism (Rebick 2018). In theory, therefore, multiple tendencies can co-exist within the NDP and use the party's democratic process to argue for the NDP to adopt their positions. Those socialist feminists who entered the NDP in the 1960s - 1980s often did so not only to sway political opinion within the party, but to recruit members to the LSA, RMG, and RWL - a tactic known as entryism. Rebick explains,

Trotskyists had this thing of intervening in the movement...You work in the movement because the movement is important to social change but also because you were trying to recruit people and that was true in the NDP as well. 
You organize inside the NDP. You organize to push the NDP to the Left but you also organize to recruit people. 121

Entry into the NDP did not necessarily mean that socialist feminists gave up their commitments to revolutionary Marxism; entryism was a strategy. ${ }^{122}$ While those activists entering into the NDP may have had to dilute their politics and sometimes hide their true intentions, they did so with a commitment to strengthening their own movements. On occasion, they did win ideological and political battles. Such was the case with Rebick's entry into the NDP to push the OCAC agenda, as I discussed in Chapter 3. Even so, some saw their time better spent elsewhere. Linda Kealey, who eventually joined the NDP, shared this opinion, "I thought the NDP was probably not worth my time back then. Not socially conscious enough or change oriented enough."123

For those socialist feminists who embraced non-hierarchical and prefigurative aspirations, it is difficult to reconcile their involvement with the NDP with their criticisms of party, hierarchy, and leadership. Many of the same apparent downsides of the Old Left are present in the NDP at an organizational level, if not the full-scale "vanguardism." For example, openly organizing an alternative leadership and program is considered a violation of party norms and punished. ${ }^{124}$ Within the NDP Caucus (NDP MPs), considered the most important component of the NDP and its

\footnotetext{
${ }^{121}$ Rebick, interview with researcher, August 6, 2018.

122 Entryism was not unique to the Trotskyists. But other communists had abandoned the idea of influencing NDP policy and direction. Instead, they focused on influencing the rank and file membership and workers that supported the NDP. In other words, they never tried to consciously change the direction of the NDP or a be a faction within the NDP.

123 Kealey, interview with author, August 13, 2018.

${ }^{124}$ I noted in Chapter 2 how different Trotskyist organizations were expelled from the party after their entryist strategy was discovered.
} 
most official expression (next to the Leader's office, which is the final arbiter), discipline is strict. The leadership decides how votes are cast, at penalty of expulsion from the Caucus and sitting as an independent, losing the party resources required for the next election campaign. Indeed, the NDP leadership and its political line is selfperpetuating and explicitly anti-socialist/Marxist/communist. Unsurprisingly, for a political party, NDP leadership exercises significant control over party policy, candidate selection, communications, and conventions. Socialist feminists understood these limitations. Despite these obvious similarities to the features criticized by many radical and socialist feminists, the decline of the radical left contributed to the view that the NDP was the main political space in which to organize. Ironically, the increasing turn towards the NDP took place at a time when socialist feminists themselves recognized that, "much of the party's policy has retreated from the socialist views of the 1970s debate, taking up instead a defensive nationalism, a social democratic version of 'fortress Canada'" (RGR 1989: 2).

Sangster (2010) argues that, "by the 1980s, what had been a socialist vision was for many becoming a social democratic one" (13). She continues, "some New Left feminists saw this shift more clearly in class as well as political terms: when asked in 2003 'what happened to the women's movement,' New Left feminist and trade activist Myrna Wood replied with some acuity, 'She got a degree and moved into an executive office" (Sangster 201: 13). Sometimes the socialist feminist turn towards the NDP or social-democratic parties generally was predicated on the possibilities this opened for greater political influence or effectiveness. In part, we can see this as an admission that political parties were and are indeed important for mobilizing larger sections of 
Canadian society. Marilyn Porter, who moved from the UK to Canada, initially joined the CPC, but found that there was no work being done by the party in Newfoundland, where she lived, and therefore no potential to make an impact. Porter argued the same about the movement nationally, noting, "the Communist Party had no seats in the House of Commons and precious little chance of gaining one" (Porter 2013: 142) and while she was "still supportive of them" that didn't change the fact that the CPC is "not a particularly useful place to work." 125 For her, it was therefore important to abandon "ideological purity in order to engage more people. It meant abandoning the direct approach to revolution and working with forms of reformism. I began to balance, precariously, between principle and practical politics. I now see that this was a key and necessary step for me to take" (Porter 2013: 142). The same was true for Kealey (2018) who eventually joined the NDP despite her initial criticisms: "once you get to smaller places there's not much other activity or politically sympathetic activity to be involved in so when I was at Memorial I did work in the NDP at St. Johns...It really depends on where you are what your political options are..."126 Adamson et. al. (1988) likewise emphasized,

currently in Canada there is no large, popular, or legitimate parliamentary communist or socialist party...The existence of the NDP and its commitment to a progressive platform on women's issues, at least in principle, has had an impact on the development of the socialist feminist strategic orientation to the government and state apparatus (123-123).

125 Marilyn Porter, interview with author, September 5, 2018.

126 Kealey, interview with author, August 13, 2018. 
Others held more conviction that the NDP could be a party that radically transformed capitalist society. In 1968, Newbigging, a member of the League for Socialist Action, argued that the NDP is "the present political vehicle for the only force that can and will transform capitalist society - the working-class. It is through the NDP that the women's liberation movement can establish ties with working women and the trade unions and thereby achieve much needed stability and direction" (4).

However, Porter (2013) admits, "as we [the NDP] get bigger and closer to real power, the trend to compromise grows stronger" (144). Therefore, as was often the case, socialist feminists struggled "between principle and compromise" (Porter 2013: 144). Indeed, socialist feminists repeatedly questioned whether women's demands could be met "by an NDP-style social democracy" or if they needed "a more revolutionary model of empowerment" (Brock and Wright 1988: 7). Stephen (1988) cautioned that, "electoral support is one way that a coalition with the NDP can defuse a social movement" (5). Striking here is Stephen's then-reference to socialist feminists' support for the NDP as a coalition. This implies that at one-point, socialist feminists aimed to maintain their own independence and organizations, and to align with the NDP as a movement, rather than be subsumed within it. But as their movements disappeared, many were left with the NDP as the only alternative. The NDP has not demonstrated itself to be capable or consistent in advocating for the working-class and mobilizing outside of the election period. While it's conceivable that a social democratic party might build capacity and work towards a socialist future, the NDP does not formally uphold socialism nor has it been good at mobilizing people while in government. 


\subsection{Reconsidering the Political Party}

At a time when progressive political organization is arguably at a 100 -year low, a new generation of activists are looking for direction to counter the ills of capitalism. American socialist feminist Johanna Brenner (2014b) argues that "rebuilding the Left will require drawing on socialist feminist traditions" (n.p). As I showed in Chapter 1, this sentiment has been echoed by other socialist feminist academics and organizers (Brenner 2014a, 2014b; Rowbotham et. al. 2013; Ferguson and Bhattacharya 2018; Ehrenreich 2018; Holmstrom 2002) but what exactly we should learn and incorporate from this history is variously interpreted.

In this dissertation, I have attempted to shed light on Canadian socialist feminist political history, development, and historic role in various community struggles. As this chapter argues, socialist feminists in Canada were of several minds about political parties and the party organizational form. However, those who fully embraced decentralized and consensus-based organizational principles may have "thrown out the baby with the bathwater." Indeed, socialist feminism was strongest when there were active socialist parties and organizations and when socialist feminists could play important roles in a vibrant national organization like, for example, the National Action Committee on the Status of Women.

In this vein, present-day crises require coordinated, sustained and accountable organization that can implement structural changes benefiting women, working people, and the future of life on the planet. An Ipsos poll taken on the eve of the 2019 federal election found that 67 per cent of Canadians agree that "Canada's economy is rigged to advantage the rich and powerful" and that 52 per cent believe 
that "Canada's society is broken" (Bricker 2019: n.p). ${ }^{127}$ A Forum Research poll in August 2019 found 58 per cent of Canadians holding a positive view of socialism. ${ }^{128}$ But those residents of Canada will not see any mainstream political parties expressing such views as plainly as the questions in these two polls, which found broad agreement. There are certainly institutional barriers - from the media, other political parties, and business, among others - to a party holding these views gaining mainstream acceptance. But the absence of representation for so many Canadians' views is striking. They and their interests deserve to be represented - including in government - and to have a party to support with a clear conscience.

Some may argue that this view neglects an analysis of political parties as oppressive institutions in themselves. Undoubtedly, hierarchy carries with it the risk of the undue use of power by those above against those below. At the same time, I've shown that non-hierarchical organizing can fall prey to the same dynamics. Most important to minimizing harm in the context of the hierarchy and institutional power of a political party is accountability. A political party also serves an important function to crystallize viewpoints in favour of socialism, and critical of a rigged economy, mainstream parties, and society, into clear policy and solutions.

Some socialist feminists may argue that this flies in the face of socialist feminism. Indeed, this dissertation has shown that the socialist feminist experience in Canada was not homogeneous and did not share a consensus around the "new

\footnotetext{
127 Similar numbers expressed agreement that "traditional parties and politicians don't care about people like them;" "Canada needs a strong leader to take the country back form the rich and powerful" and; "Experts in this country don't understand the lives of people like them" (Bricker 2019: n.p).

12818 per cent reported a "very positive opinion" (Forum Poll 2019).
} 
politics" and organizing emerging from the New Left. As I demonstrated in Chapter 2, socialist feminists had strong ties to the Trotskyist movement, which followed in the tradition of democratic centralism. That said, many gradually left democratic centralism behind in favour of new organizational forms. In Canada, many of the official and unofficial leaders of socialist feminist organizations were women members of Trotskyist organizations like the League for Socialist Action, Revolutionary Marxist Group, and Revolutionary Workers' League. Socialist feminist groups like the Vancouver Women's Caucus, International Women's Day Committee, and Toronto Socialist Feminist Action took a different approach and were never able to form a national organization or party structure, nor was this their goal. Yet they held as their goal the toppling of Canadian capitalism and ushering in a socialist society. While efforts to form horizontal and consensus-based organizations were a response to the sexism and discrimination women were encountering in traditional left organizations and parties (like those mentioned above), non-hierarchy and consensus were not the answers, just as structure and democratic decision-making were not the problem in themselves. Structural factors affected women's participation in the movement, including child-rearing and homemaking obligations without significant state support, and lack of infrastructure to accommodate these requirements. This much is evident from the experience of communist women in SUPA (some who later identified as socialist feminists), which purported to be a horizontal organization. Furthermore, in socialist feminist organizations, Indigenous and racialized women often reported feeling marginalized not unlike the way that socialist feminists felt inside Old Left and New Left organizations. Eliminating a 
formal leadership structure was therefore not, in itself, a solution to the problem. Freeman, Steinecker, and Adamson's critiques of the women's movement and socialist feminist groups indicate that these new forms of organization could indeed compound the problem.

\subsection{Conclusion}

Many of the organizational methods and structures of the New Left were wellsuited to consciousness-raising and providing services to women. Additionally, they worked well for smaller scale and decentralized initiatives. For many who elaborated socialist feminist politics, their successes gave rise to a confidence that the movement's achievements were owed to these distinctive politics, and that socialist feminism and the women's movement would grow and expand together (Brenner 2014a, 2014b; Rowbotham et. al. 2013; Holmstrom 2002). In its most blithe expression, this included the belief that the collapse of the socialist left in the late 1980s - early 1990s would pave the way for socialist feminism to reach its potential (Weir 1987). However, not only did this fail to occur, but socialist feminism as a movement suffered much the same fate as the rest of the left following the counterrevolutions in the Soviet Union and other socialist-identified countries in Europe. Arguably, reactionary or anti-socialist forces have gained strength since that time, while revolutionary or socialist politics have had little, if any, recovery. The status quo image of politics as a choice between neo-liberalism (Trudeau, Obama, Macron, Merkel) and far-right revanchism (Trump, Canada's Conservatives, Le Pen) appears as the ultimate conclusion of the efforts to erase socialism from the vocabulary of the women's movement and labour movement, among others. Suddenly, not only is the 
left no longer brimming with energy, it is isolated, and its permitted expression is reduced to ineffectual critique.

While the political necessity remains, including the unfinished work of women's liberation, in Canada, and arguably internationally, the movement is lacking. What may be lacking most acutely is organization. For the ruling classes, political parties and state institutions have not lost their relevance as instruments of agitation, organization, and rule. A modern socialist left must be conscious of what tools cannot be discarded, or indeed are most critical, if it hopes to organize people in the thousands and millions required to bring about transformative, revolutionary change.

Reflecting on socialist feminism from our vantage-point today, socialist feminists brought various segments of the women's movement together around bold demands and engaged people in different and sometimes liberating forms of activism. When political parties would not adequately organize around so-called women's demands, socialist feminists committed themselves to building a movement of women from various political backgrounds. In doing so, they won important advances around reproductive rights and made gains in the labour movement. Furthermore, their critique of capitalism became the subject of debate within the women's movement.

While socialist feminists' experiments with New Left forms of activism did help to win some demands, they could be unrealistic about questions of leadership and political parties to the detriment of the socialist movement. The disinclination towards parties, leadership, and organization may have, in a classic ironic reversal, 
contributed to the movement's lack of endurance to this day. This danger was identified by socialist feminists themselves. This is not to say that the groups (SUPA, CPC, CPC (ML), RWP) at which socialist feminist thinkers aimed many of their critiques were correct or effective. They too lost momentum or disappeared by the 1990s. Rather, it is to note that the lack of a mass socialist political party and other instruments of power is a disadvantage, not a blessing. 


\section{Appendix}

I want to extend a special thank-you to everyone who contributed to this project whether through interviews, donations of materials, access to archives, or general advice. This project would not have been possible without your help.

\section{Interviews}

This list includes the names of the political groups that interview participants mentioned being involved during the 1960s - 1980s. It is not meant to be a comprehensive list of their organizational affiliations or work.

Meg Luxton, July 19, 2018

RMG, RWL, NAC, Toronto Women's Liberation, Women's Press

Professor

Toronto

Judy Rebick, August 6, 2018

NAC, RMG, RWL, NDP, OCAC

Journalist

Toronto

Carolyn Egan, October 1, 2018

OCAC, IWDC, Students for Democratic Society, Women's Liberation Movement, TSFA

President of the Steelworker Toronto Area Council

Toronto

Elizabeth Rowley, January 4, 2019

CPC, NAC, IWD

Leader of Communist Party of Canada

Toronto

Marilyn Porter, September 5, 2018

UK Women's Movement, CPGB, RMG, CPC, NDP

Professor

Bristol (UK), Newfoundland

Linda Kealey, August 13, 2018

New Left Caucus, Women's Press, Women's Liberation Movement, NS

Women's Action Committee, NDP

Professor

Rochester (US), Toronto, Nova Scotia, New Brunswick

Marjorie Griffin Cohen, August 26, 2018

NAC, Coalition Against Free Trade, OFL, CLC 
Professor

Toronto

Debbie Field, November 8, 2018

OPSEU, NAC, Stelco, RWL, RMG, CLC, OFL, OWW

Coordinator at the Coalition for Healthy Food

Toronto, Hamilton

Kathryn Petersen, August 31, 2018

Young Socialist Alliance, Toronto Women's Liberation, Daycare

Centre, RMG, RWL, CUPE, Old Mole

Hamilton Public Library

Chicago (US), New York (US), Toronto, Hamilton

Amy Gottlieb, December 6, 2018

RMG, IWDC, Jewish Women's Committee Against the Occupation

Artist and Activist

Toronto

Varda Burstyn, January 10, 2019

Women's Liberation Movement, Pollution Probe, NDP, IWDC, RMG, RWP

Writer and Scholar

Toronto

\section{Resources}

This is a list of resources consulted in addition to the works cited.

\section{Author's Personal Collection}

A Conference for Socialist-Feminist Women Correspondence (1982)

"Bread and Roses," McAfee and Wood, Vancouver Women's Caucus (1969)

"Consumerism and Women," Toronto Women's Liberation (n.d.)

Fact Sheet: Organized Working Women, OWW (n.d.)

Feminist-Socialist Conference Correspondence (1983)

IWDC Correspondence, IWDC (February 9, 1983)

IWDC Correspondence, IWDC (February 4, 1983)

IWD Open House and Celebration Poster, March $8^{\text {th }}$ Coalition (1983)

International Women's Day Pamphlet (1978)

International Women's Day Pamphlet (1979)

International Women's Day Pamphlet (1981)

International Women's Day Pamphlet (1982)

"Is A Machine After Your Job," Worker's Action (n.d.)

OWW Skills Building Workshop, Peterborough (November 1982)

OWW Correspondence, Deirdre Gallagher (1979)

Socialist-Feminist Conference Newsletter (May 1983) 
"The Fight for Health and Safety," Toronto Clarion (February 12, 1982)

"They Are Burning Effigies," Peggy Morton (1975)

Toronto Women's Liberation Newsletter (n.d.)

"We're Worth More!", NAC (1990)

Women - Reform or Revolution, Melody Kilian (1968)

Rise Up Feminist Archive - https://riseupfeministarchive.ca/

Action Now, National Action Committee (1990)

Action Bulletin, National Action Committee (1985-1989)

Angela Davis: International Women's Day, IWD (1985)

Black Women's Collective National Day of Action Pro-Choice Statement (1989)

Cayenne: A Socialist Feminist Bulletin

Canada's Women, CPC (1963)

Canadian Labour Congress Statement on Women's Rights (1974)

Equal Times, Federal NDP Women's Organizer (April 1982)

Feminist Action, National Action Committee (1985-1991)

International Women's Day Committee Newsletter (1979-1986)

IWD Basis of Unity Statement (1979)

IWDC Women's Strike Support (1979)

Open Letter to March 8th Coalition, Black Women's Collective (1989)

Organize IWD 1979

Pan Canadian Preconvention Discussion Bulletin, RWL (1979)

Priorities, Federal NDP Women's Organizer

Rally Against Racism Statement, Black Women's Collective (1989)

Rebel Girls' Rag: A Forum of Women's Resistance (1987-1992)

Submission to the 1973 LSA/LSO Convention on Women's Liberation (1973)

The Grapevine, Organized Working Women (Dec. 1987, Feb. 1988, Jan. 1989)

The Womanist (1988-1989)

Tiger Lily: A Journal by Women of Colour

"The IWDC - We Continued the Fight," IWDC (1978)

“The Daycare Kit," The Daycare Research Group (1982)

Toronto International Women's Day Speech delivered Angela Robertson (1989)

Toronto IWD Chronology, 1978-1982

Union Women, OWW

Union Woman, Organized Working Women

Vancouver International Women's Day Brochure (1986)

Wages for Housework Campaign Bulletin (Spring 1977, Autumn 1977)

Working Women, Saskatchewan Working Women (Apr. 1980, Apr. 1979)

“Women's Liberation," Revolutionary Marxist Group (1975)

\section{Canadian Women's Movement Archives - Ottawa}

"Labour Power," Peggy Morton (1972)

"The status of women in Canada," League for Socialist Action (1968)

“Today's Woman: A Marxist-Leninist View," New Outlook Publishers (1970) 
"Women and Socialism," Vancouver Women's Study Group (circa 1970)

"Women's Work," Working Women's Association (1982)

"Woman's Work is Never Done, or, the Production Maintenance and Reproduction of Labour Power," Peggy Morton (1971)

"You Can't Make A Revolution Without Them," Margaret Randall (1975)

\section{Communist Party of Canada Collection - Toronto}

As One! For Equality, For Happiness, For Peace, World Congress of Women (1953)

Compilation of Articles of Women's Struggles from YCL-LJC Publications (2014)

Declaration on the Rights of Canadian Women, Congress of Canadian Women (1953)

New Horizons: A Socialist Perspective for Youth (1978-1983)

New Worlds for Women, Dorise Nielson (1944)

Rebel Youth (1981-1990)

"Your Husband is a Union Man!", Canadian Labour Congress (1956)

Young Worker (1976-1978)

Ontario Archives - York University

"Conference of the Chiefs of Women's Departments of EU Communist Parties," CPC (1930)

International Women's Day, CPC Women's Department (1931)

Letter from Alice Buck to secretaries of WLL (1930)

Letter from Canadian Defense League to WLL (1931)

"Participation of Women Workers in Economic Battles," CPC (n.d.)

"Party Work Among Women," CPC (n.d.)

"Work Among Women for Campaign Against Embargo on Soviet Union," CPC (1931)

Report of European Communist Parties Conference on Woman's Work, CPC (n.d.)

“Bourgeois Women's Organizations in Canada," CPC Women's Department (n.d)

"Resolution on Work Among Women and the Tasks of the Parties," CPC (1931)

"Resolution on Woman's Work," CPC and National Women's Department (1931)

The First Canadian Working Women's Delegation to the Soviet Union, CPC (1931)

"The Status of Working-Class Women in Canada," CPC (1930)

"Women and the Fight for Socialism," Becky Buhay (1948)

Canada's First World War Experience Online Collection - vimyridgehistory.com

"Anything New in War Work?", Government of Canada (n.d.)

"Canadian Women in the Great War," Military Advisory Board (1921)

"War and Women," MacDonald (1918)

Women in the Production of Munitions in Canada, Imperial Munitions Board (1916)

"Women's Work," Department of External Affairs (1921) 


\section{Works Cited}

Abella, Irving. The Canadian Labour Movement, 1902-1960. Ottawa: Canadian Historical Society.

Action Daycare. 1982a. "A Daycare Conference." IWDC Newsletter 4(4): 2. Retrieved October 31, 2018 (https://goo.gl/5pquKF).

----. 1982b. “The Daycare Kit.” Retrieved October 31, 2018 (https://goo.gl/4ab1CC).

----.. n.d. "Action Daycare Letter." Retrieved October 31, 2018 (https://goo.gl/BF52X7).

Adams, Howard. 1995. Prison of Grass: Canada From a Native Point of View. Saskatoon: Fifth House Books.

Adamson, Nancy. 1984. “Dear IWDC" in IWDC Newsletter 6(4): 2.

Adamson, Nancy and Anne Molgat. 1988. "The Mystique of Feminist Process: A Report from the NAC AGM." Cayenne 4(2): 5-6.

Adamson, Nancy, Linda Briskin and Margaret MacPhail. 1988. Feminist Organizing for Change: The Contemporary Women's Movement in Canada. Toronto, $\mathrm{ON}$ : Oxford University Press.

Adamson, Nancy and Susan Prentice. 1985. "Towards a Broader Strategy for Choice." Cayenne 1(3): 3-8. Retrieved October 31, 2018 (https://goo.gl/XhLhV2).

Angus, Ian. 1977. “A Brief History of Canadian Trotskyism, 1928-1939.” Retrieved November 11, 2019 (https://bit.ly/33zwVky).

Anderson, Doris and Maude-Emmanuelle Lambert. 2006. "National Action Committee on the Status of Women." The Canadian Encyclopedia. Retrieved October 20, 2018 (https://goo.gl/cZRHfk).

Andrew, Caroline, Pat Armstrong, Hugh Armstrong, Wallace Clement and Leah Vosko. 2003. Studies in Political Economy: Developments in Feminism. Toronto: Women's Press.

Austin, Dave. 2013. Fear of a Black Nation: Race, Sex, and Security in Sixties Montreal. Toronto: Between the Lines.

Armstrong, Pat and Hugh Armstrong. 1987. "Looking Ahead: The Future of Women's Work." Australian-Canadian Studies (3): 1-11. 
Armstrong, Pat and Ann Pederson. 2015. Women's Health: Intersections of Policy, Research, and Practice. Toronto: Women's Press.

Arruzza, Cinzia, Tithi Bhattacharya, and Nancy Fraser. 2019. Feminism for the 99\%: A Manifesto. New York: Verso.

Ashwin, Sarah. 2000. Gender, State, and Society in Soviet and Post-Soviet Russia. London: Routledge.

Bacchi, Carol Lee. 1983. Liberation Deferred?: The Ideas of the English-Canadian Suffragists, 1877-1918. Toronto: University of Toronto Press.

Bader-Zaar, Birgitta. 2017. “Controversy: War-Related Changes in Gender Relations: The Issue of Women's Citizenship." International Encyclopedia of the First World War. Retrieved October 30, 2019 (https://bit.ly/2q4ScUn).

Bannerji, Himani. 1995. Thinking Through: Essays on Feminism, Marxism, and Anti -Racism. Toronto: Women's Press.

Baggins, Brian. 2010. "Origin of the Family, Private Property, and the State." Marxist Internet Archive. Retrieved August 17, 2017 (https://goo.gl/UUcoAn).

Baker, Maureen and Mary-Anne Robeson. 1981. "Trade Union Reactions to Women Workers and Their Concerns." The Canadian Journal of Sociology 6(1): 19 $-31$.

Barker, Colin, Laurence Cox, John Krinsky, and Alf Gunvald Nielson. 2013. Marxism and Social Movements. Leiden: Brill.

Barker, Donna. 1987. "Anatomy of Working with a White Collective." Our Lives 2(3): 12-13.

Barker, Joanne. 2008. “Gender, Sovereignty, Rights: Native Women's Activism Against Social Inequality and Violence in Canada." Johns Hopkins University Press 60(2): 259-266.

Barrett, Paul. 2017. "In Canada, the Killing of Black Men by Police Never Seems to Be About Race." Rabble. Retrieved November 11, 2019 (https://bit.ly/34qoI0).

Bashevkin, Sylvia. 1989. "Free Trade and Canadian Feminism: The Case of the National Action Committee on the Status of Women." Canadian Public Policy 15(4): $363-375$.

----. 2002. Welfare Hot Buttons: Women, Work, and Social Policy Reform. Toronto: Toronto University Press. 
Bebel, August. 1910 (1879). Women and Socialism. New York: Cooperative Press. Retrieved July 30, 2015 (https://goo.gl/s9Lp7B).

Benston, Margaret. 1969. “The Political Economy of Women's Liberation.” Monthly Review 41(7): 31-44.

Bernstein, Judi and Peggy Morton, Linda Seese, and Myrna Wood. 1967. "Sisters, Brothers, Lovers...Listen..." Rise Up! Feminist Archive. Retrieved December 2, 2018 (https://goo.gl/6Q1pAq).

Betteridge, Lise. 1986. "Facing the Daycare Crisis: A Campus Forum." Otherwise. 2(5): 9. Retrieved October 30, 2018 (https://goo.gl/gEDvKz).

----. 1986b. “Sisterhood Must Be Struggled For.” Our Lives 1(1): 31-33.

Bezanson, Kate and Meg Luxton. 2006. Social Reproduction: Feminist Political Economy Challenges Neo-Liberalism. Montreal: McGill-Queen's Press.

Bhavnani, Kum-Kum and Margaret Coulson. 2005. "Transforming Socialist Feminism: The Challenge of Racism." Feminist Review 80(1): 87-97,

Blanc, Eric and Jeremy Gong. 2018. "How Class Should be Central." Jacobin. Retrieved September 5, 2019 (https://bit.ly/2ly2x9g).

Boxer, Marilyn. 2007. "Rethinking the Socialist Construction and International Career of the Concept of 'Bourgeois Feminism.'” The American Historical Review 112 (1): 131 - 158.

Bradbury, Bettina. 1987. “Women's History and Working-class History.” Labour/Le Travail 19 (Spring): 23-36.

Bradburn, Jamie. 2011. “All Haile Canada's First Female MPP Candidate.” Torontoist. Retrieved November 3, 2019 (https://bit.ly/2oMo004).

Brenner, Johanna. 2014a. “21 ${ }^{\text {st }}$ Century Socialist feminism.” Socialist Studies 10(1): $31-49$.

Brenner, Johanna. 2014b. “The Promise of Socialist feminism.” Jacobin. Retrieved July 9, 2019 (https://bit.ly/1v0QLh2).

----. 2016. "Socialist Feminism in the 21st Century." Canadian Dimension. Retrieved September 22, 2019 (https://bit.ly/2kVGadG). 
Bricker, Darrell. 2019. "As Election Looms, Majority of Canadians (52\%, Up 15 Points since 2016) Say Canada's Society is Broken." IPSOS. Retrieved September 27, 2019 (https://bit.ly/2lF6FUZ).

Briskin, Linda. 1999. "Mapping Women's Organizing in Sweden and Canada: Some Thematic Considerations" Pp. 3-50 in Women's Organizing and Public Policy in Canada and Sweden edited by L. Briskin and M. Eliasson. Montreal and Kingston: McGill-Queen's University Press.

----. 1989. "Socialist feminism: From the Standpoint of Practice." Studies in Political Economy 30 (Autumn): 87-114.

Briskin, Linda and Lorna Weir. 1981. "Rising Up Strong.” Retrieved July 23, 2018 from (https://goo.gl/UvhsDK).

Briemberg, Liz. 2019. "Daycare Should Be Available Free for All Children." Vancouver Women's Caucus: A Women's Liberation History Project. Retrieved June 25, 2019 (https://bit.ly/2S5gfwe).

Broadside. 2012. "What was Broadside." Retrieved October 17, 2018 (http://www.broadsidefeminist.com/).

Brock, Debi and Wright Cynthia. 1988. "Feminists Organizing for Change." Rebel Girls' Rag 3 (1): 7.

Brodie, Janine. 1996. Women and Canadian Public Policy. Toronto: Harcourt Brace \& Company, Canada.

Bronskill, Jim. 2018. “New Book Says RCMP Looked at Women's Movement Through 'Red Tinged Prism." The Star. Retrieved November 20, 2019 (https://goo.gl/SQhCJ5).

Brown, Robert and Ramsay Cook. 1974. Canada: A Nation Transformed. Toronto: Penguin Random House Canada.

Bubeck, Elisabet. 2004 [1995]. Care, Gender, and Justice. Oxford: Oxford University Press.

Buhay, Becky. N.d.-a circa 1930s. Buhay Correspondence to District Labour Committees. Communist Party of Canada (11C3067, Box 11, Folder 33). Archives of Ontario, Toronto, Canada.

----. N.d.-b circa 1931. How to Reach the Masses of Working Class Women [report]. Communist Party of Canada. (11C289, Box 11, Folder 32). Archives of Ontario, Toronto, Canada. 
Burnham, Linda and Miriam Louie. 1985. The Impossible Marriage: A Marxist Critique of Socialist feminism. Oakland, CA: Line March: A Marxist-Leninist Journal of Rectification.

Canada Revenue Agency. 2019. "T4114 Canada Child Benefit and Related Provincial and Territorial Programs." Retrieved November 3, 2019 (https://bit.ly/36sSdCh).

Callinicos, Alex and Roy Bhaskar. 2003. "Marxism and Critical Realism." Journal of Critical Realism 1 (2): 89-114.

Carr, Edward Hallett. 1961. What is History? Harmondsworth: Penguin Books

Canada Broadcast Company (CBC). 2018. "50 Years Ago, the Women of Canada's 'Abortion Caravan' Stormed Parliament for Reproductive Rights." The Sunday Edition, June 3, (https://goo.gl/7JePzs).

----- 2001. “Communist Canada: Ottawa Clamps Down When Canadians Find Hope in the Communist Movement" in Canada: A People's History. Retrieved March 23, 2019 (https://goo.gl/1GvGmP).

----. 2001. "Boom and Bust in Alberta." Canada: A People's History. Retrieved November 18, 2018 (https://goo.gl/7hSLRR).

----. 1998. "Daycare During Wartime" in CBC Digital Archives. Retrieved July 13, 2019 (https://bit.ly/2Sia4oL).

Canadian Auto Workers (CAW). N.d. "The 1930s." Retrieved November 11, 2019 (https://bit.ly/2Q8f9Rz).

Cayenne. 1985. "Native Women." Cayenne 1(2): 19-21. Retrieved October 15, 2018 (https://goo.gl/HJKcKX).

Chappelle, Louise. 2002. Gendering Government: Feminist Engagement with the State in Australia and Canada. Vancouver: UBC Press.

Chenier, Nancy. 2006. “Canadian Women and War.” Canadian Encyclopedia. Retrieved October 26, 2018 (https://goo.gl/m3zsM4).

Chrysochou, Theopoula. 2013. "Engels and the Debate on Women's Oppression" Paper presented at the 24th International Congress of History of Science, Technology and Medicine, July 24, Chelmsford, UK. Retrieved September 16, 2017 (https://goo.gl/qzuQ5v). 
Coalition for Visible Minority Women. 1987. "Free Trade Agreement: What it Means to be Immigrant and Visible Minority Women." Our Lives 2(4): 11. Retrieved October 30, 2018 (https://goo.gl/n7A51o).

Cohen, Phil. 2018. "The Politics of Memory" interview with KPFA's Against the Grain. Retrieved March 11, 2019 (https://bit.ly/2xyhIC2).

Cohen, Marjorie and Jane Pulkingham. 2009. "Public Policy for Women: The State, Income Security and Labour Market Issues." Studies in Comparative Political Economy and Public Policy 32 (32): 1 - 417.

Collins, K. 1931. Correspondence National Women's Department to Woman's Labour Leagues [letter]. (11C3089, Box 11, Folder 33). Archives of Ontario, Toronto, Canada.

Communist Party of Canada. N.d. "The Textile and Clothing Industry in Canada" [report]. (11C2937). Archives of Ontario, Toronto, Canada.

----- N.d.-b. "Party Work Among Women Canada” [report]. (Box 11, Folder 32). Archives of Ontario, Toronto, Canada.

Connelly, Patricia. 1978. Last Hired, First Fired: Women and the Canadian Work Force. Toronto: Women's Press.

Connelly, M.P. 2015. "Women in the Labour Force." Historica Canada. Retrieved June 27, 2016 (http://goo.gl/jLl1hH).

Copp, Terry. 1982. "The Rise of Industrial Unions in Montreal 1935-1945." Labour / Le Travail 37 (4): 843-875.

Cozzarelli, Tatiana. 2019. "DSA Convention 2019: Sanderism and the Tyranny of the Procedural." Left Voice. Retrieved November 17, 2019 (https://bit.ly/2NV05oL).

Custance, Florence. 2015 [1924]. "Report to the 1924 Convention." Retrieved November 11, 2019 (https://bit.ly/2X5mSBf).

Daly, Mary. Gyn/ecology: The Metaethics of Radical Feminism. Boston: Beacon Press.

Day, Richard. 1973. Leon Trotsky and the Politics of Economic Isolation. London: Cambridge University Press.

Davis, Angela. 1983. Women, Race, and Class. New York: Vintage Books. Retrieved September 19, 2019 (https://bit.ly/2EgOtaU).

Dean, Jodi. 2016. Crowds and Party. New York: Verso. 
De Wolff, Alice. 2006. "Bargaining for Collective Responsibility for Social Reproduction" Pp. 93-116 in Social Reproduction: Feminist Political Economy Challenges Neoliberalism. ON: McGill-Queen's University Press.

Dill, Bonnie. 1983. "Race, Class, and Gender: Prospects for an All-Inclusive Sisterhood." Feminist Studies 9 (1): 131-150.

Dixon, Marlene. 1977. “The Rise and Demise of Women's Liberation: A Class Analysis." Marxist Internet Archive. Retrieved March 11, 2019 (https://goo.gl/nb9juu).

Douglas, Carol Anne. 1980. "What the Hell is a Radical Feminist?" Off Our Backs: A Women's News Journal 10 (2): 15.

Dworkin, Andrea. Woman Hating. New York: E. P. Dutton

Edgar, David. 2018. "The Radical Legacy of 1968 is Under Attack. We Must Defend It." The Guardian, May 10, (https://goo.gl/7FLWLM).

Egan, Carolyn. 1987. “Toronto International Women's Day Committee: Socialist Feminist Politics" Pp. 109 - 118 in Feminism and political Economy eds. Heather Jon Maroney and Meg Luxton. Toronto: Methune.

Egan, Carolyn and Shelly Gordon. 1988. "No to Free Trade, Yes to Full Employment." Rebel Girls' Rag 2 (2): 2. Retrieved October 30, 2018 (https://goo.gl/U45ev9).

Ehrenreich, Barbara. 2018. "What is Socialist Feminism?" Jacobin. Retrieved May 15, 2019 (https://bit.ly/2Vv8WOG).

Eisenstein, Hester. 2009. Feminism Seduced: How Global Elites Use Women's Labor and Ideas to Exploit the World. London: Paradigm Publishers.

Elbaum, Max. 2018. Revolution is in the Air. New York: Verso.

Engels, Friedrich. 2007 [1884]. The Origin of the Family Private Property and the State. New York: International Publishers.

Engler, Yves. 2015. Canada in Africa: 300 Years of Aid and Exploitation. Halifax: Fernwood Publishing.

Engler, Yves. 2013. "Our Shame: Canada Supported Apartheid South Africa." Canadian Dimension. Retrieved November 3, 2019 (https://bit.ly/2pt0V2Y). 
Epstein, Barbara. 1995. "Why Poststructuralism Is a Dead End for Progressive Thought." Socialist Review 25(2): 83-119.

Epstein, Rachel and Jenny Horsman. "Dear Cayenne." Cayenne 2 (4): 2 -3. Retrieved September 24, 2019 (https://bit.ly/2mqQb3c).

Executive Committee. 1930. “Report of the National Executive Canadian Women's Committee for a Working Woman's Delegation to the USSR on the Selection of a Delegation." (11C2965, Box 11, Folder 32).

Ferguson, Susan. 2008. “Canadian Contributions to Social Reproduction Feminism, Race and Embodied Labor." Race, Gender, and Class 15 (1-2): 42-57. (https://goo.gl/gL7vHu).

----. 2014. “A Response to Meg Luxton's 'Marxist Feminism and Anticapitalism.'” Studies in Political Economy 94 (1): 161-168.

Ferguson, Susan and Tithi Bhattacharya. 2018. "Socialist Feminism for the $21^{\text {st }}$ Century.” Audio Recording. New Socialist. Retrieved May 15, 2019 (https://bit.ly/2W4RZPr).

Fernandez, Sharon, Betty Julian, Jude Johnston, Christ Lawrence, Beth McAuley, Marilyn McCallum, Stephanie Martin, Joanne Opperman, Esther Vise, and Wendy Wine. 1987b. “Toronto Women's Bookstore.” Rebel Girls' Rag 2(1): 2 -3 .

Firestone, Shulamith. 1970. The Dialectic of Sex: The Case for Feminist Revolution. New York: Farrar, Straus and Giroux.

Floresco, Aaron. 2012. "A Struggle to Remember: Fighting for our Families.” Video. Rise Up Feminist Archive. Retrieved September 22, 2019 (https://bit.ly/2m8SVSn).

Foley, Barbara. 2018. "Intersectionality: A Marxist Critique." Monthly Review Online. Retrieved August 31 [https://bit.ly/2PvGoHf].

Fong, Benjamin and Andrew Sernatinger. 2019. "Reading the Resolutions: Two Perspectives." Democratic Socialists of America. Retrieved November 17, 2019 (https://bit.ly/37dfEjp).

Forum Poll. 2019. "Majority of Canadians Have Positive Opinions of Socialism, But Americans Hold a Different Opinion." Forum Research. Retrieved September 27, 2019 (https://bit.ly/2lDeudY).

Fourt, Anne. 1987. "Strategies for Daycare." Cayenne 11 (12): 2-10. Retrieved November 2, 2018 (https://goo.gl/jzAdPW). 
Fourt, Anne. 1986. “Impressions of IWD.” Cayenne 2(3): 28. Retrieved September 24, 2019 (https://bit.ly/2k00Xyc).

Fourt, Anne, Nancy Jackson, Marie Lorenzo, Liza McCoy, Judi Stevenson, and Lynda Yanz. 1989. "Cayenne: A Socialist Feminist Bulletin: Goodbye Letter." Retrieved September 22, 2019 (https://bit.ly/2m23yqe).

Frader, Laura and Sonya Rose. 1996. "Introduction: Gender and the Reconstruction of European Working-Class History" Pp. 1-33 in Gender and Class in Modern Day Europe edited by L. Frader and S. Rose. New York: Cornell University Press.

Frager, Ruth and Carmela Partias. 2005. Discounted Labour: Women Workers in Canada, 1870-1939. Toronto: Toronto University Press.

Frances, Raelene, Linda Kealey and Joan Sangster. 1996. "Women in Waged Labour in Australia and Canada, 1880-1980." Labour / Le Travail 71(Fall): 54-89.

Freeman, Jo. 1970. "The Tyranny of Structurelessness." Retrieved December 7, 2018 (https://goo.gl/MsxvJt).

Freeman, Linda. 1997. The Ambiguous Champion: Canada and South Africa in the Trudeau and Mulroney Years. Toronto: University of Toronto Press.

Fuller, Abigail. 2004. "Toward an Emancipatory Methodology for Peace Research" Pp. 91-109 in Critical Strategies for Social Research edited by W. Carroll. Toronto: Canadian Scholars' Press.

Fourth International. 1938. "The Founding Conference of the Fourth International." Retrieved November 3, 2019 (https://bit.ly/2C79Rxp).

Gellatly, Mary. 1988. “I.S. Challenged.” Rebel Girls’ Rag 2(3): 6 - 8.

Ghodsee, Kristen. 2018. Why Women Have Better Sex Under Socialism: And Other Arguments for Economic Independence. London: Vintage.

Gilbert, Marianne. 1975. "Who Will Mind the Baby When the Mother Goes to Vote?" Priorities 3(3): 18-19. Retrieved October 31, 2018 (https://goo.gl/BT5Hga).

Gilman, Nils. 2017. "The Cold War and the Welfare State." The American Interest. December 4, 2017, (https://goo.gl/szBtmR).

Goldman, Wendy. 1995. Women, the State, and Revolution: Soviet Family Policy and Social Life, 1917 - 1936. New York: Cambridge University Press. 
Gordon, B. N.d. [circa 1930]. “The First Canadian Working Women's Delegation to the Soviet Union." (11C2962, Box 11, Folder 32). Archives of Ontario, Toronto, Canada.

Gordon, Linda. 2013. "Socialist Feminism: The Legacy of the 'Second Wave.'” New Labor Forum. Retrieved March 11, 2019 (https://goo.gl/YvnDtS).

Gorham, Deborah. 1988. “Feminism: Some Recent Canadian Contributions.” Labour / Le Travail 22 (Fall): 267-272.

Gottlieb, Amy. 1983. “Debates in the Women's Movement.” IWDC Newsletter 5(3): 2. Retrieved October 16, 2018 (https://goo.gl/1CSqR7).

Government of Canada. 2016. "Royal Commission on the Status of Women in Canada." Retrieved October 12, 2018 (https://cfc-swc.gc.ca/abu-ans/wwad -cqnf/roycom/index-en.html).

----. 1914 (circa). “'Support and Substitution:' Women's Roles during World War I.” McMaster University Digital Archives. Retrieved December 1, 2017. (Link is no longer available).

Grace, Lisa Grace. 2007. “Women's Work; Great Gains Have Been Achieved Through the Past Century, but a New Exhibit Offers this Warning: Take Nothing for Granted. What Has Been Won Can Slip Away." The Hamilton Spector. March 13. Retrieved November 3, 2019 (https://bit.ly/2JLpdf8).

Grady, Sylvia. 2018. "Voice of Women." Rise Up Feminist Archive. Retrieved October 26, 2018 (https://goo.gl/qp8DAk).

Gregory, Frances. 1977b. "When's Pay Day?" Wages for Housework Campaign Bulletin 2(1): 4.

Hall, Anthony. 2011. "Treaties with Indigenous Peoples in Canada." The Canadian Encyclopedia. Retrieved October 30, 2019 (https://bit.ly/2NsPOyC).

Hanson, Eric. 2009. "Marginalization of Aboriginal women.” First Nations and Indigenous Studies: The University of British Columbia. Retrieved September 12, 2018 (https://goo.gl/hJX68q).

Harman, Chris. 1984. "100 Years on the Origins of Family.” Socialist Worker Review. 68 (September): 15-20.

----. 1990. "From Trotskyism to State Capitalism." International Socialist 2(47). Retrieved November 3, 2019 (https://bit.ly/2oNegCQ). 
Harris, Christopher. 2009. "Black from the Inside." Upping the Anti 5(December). Retrieved November 19, 2019 (https://bit.ly/2xBev4B).

Harriss, Kathryn. 1980. "New Alliances: Socialist feminism in the Eighties." Feminist Review 31 (Spring): 34 - 54.

Henderson, William. 2016. "Indian Act." The Canadian Encyclopedia. Retrieved July 9, 2017 (https://bit.ly/2sPkhRq).

Hewitt, Stephen. 2002. Spying 101: The RCMP's Secret Activities at Canadian Universities, 1917-1997. Toronto: Toronto University Press.

Hinton, Alexander, Andrew Woodford, and Jeff Benvenuto. 2014. Colonial Genocide in Indigenous North America. Durham: Duke University Press.

Holmstrom, Nancy. 2002. The Socialist Feminist Project: A Contemporary Reader in Theory and Politics. New York: Monthly Review Press.

Hough, Jennifer. 2014. "Renowned 'Nazi hunter' says Canada still a haven for scores of war criminals who will likely never face justice." National Post, June 22. Retrieved November 13, 2019 (https://bit.ly/2tsYMpX).

Huot, John. 2016. "Autonomist Marxism and Workplace Organizing in Canada in the 1970s." Upping the Anti 18 (June). Retrieved July 15, 2019 (https://bit.ly/2XQDBY3).

Imperial Munitions Board Canada. 1916. Women in the Production of Munitions in Canada. Retrieved July 8, 2019 (https://bit.ly/2XtHcuM).

International Socialists. 1987. "I.S. Invites Debate." Rebel Girls' Rag 2(1): 7.

International Women's Day Committee. 1983a. “Thinking about International Women's Day." IWDC Newsletter 5(2): 2. Retrieved October 16, 2018 (https://goo.gl/fnGg79).

----. 1983b. "Letter to Broadside." Broadside 4 (7): 2-3. Retrieved October 16, 2018 (https://goo.gl/4a3Wbm).

----. 1983c. "That Arms Race is a Women's Issue." IWDC Newsletter 5(5): 2.

----. 1983d. "Get Your Facts Straight, Broadside." IWDC Newsletter 5(1): 4. Retrieved October 17, 2018 (https://goo.gl/JYA8vb). 
----. 1982a. "Microtechnology: An Important Issue for Women and Unionists." IWDC Newsletter 4 (3): 3. Retrieved October 29, 2018 (https://goo.gl/Bes3Ro).

----. 1982b. "IWDC is a Socialist feminist Group." IWDC Newsletter 4 (4): 1. Retrieved October 18, 2018 (https://goo.gl/gS3MbD).

----. 1982c. IWDC Newsletter 4(1). Retrieved October 10, 2018 (https://bit.ly/2kST3oY).

----. 1982d. “Upcoming Events.” IWDC Newsletter 4 (3). Retrieved October 29, 2018 (https://goo.gl/Bes3Ro).

----. 1982e. "March Against War in Central America." IWDC Newsletter 4 (2). Retrieved October 29, 2018 (https://bit.ly/2mnjd3v).

----. 1984. "Talking About Socialist feminism." IWDC Newsletter 6(2): 12-14. Retrieved April 19, 2019 (https://bit.ly/2XCv5vi).

----. 1986. “Some White Women's Response to March 8." IWDC Newsletter 8(2). Retrieved October 10, 2018 (https://goo.gl/HJFLSG).

---- 1982f. IWDC Newsletter 4(1). Retrieved October 10, 2018 (https://bit.ly/2kST3oY).

---- 1980. IWDC Newsletter 2(1). Retrieved October 10, 2018 (https://bit.ly/2kSczBS).

---- 1983e. “Why Peace Now?” IWDC Newsletter 5(1). Retrieved October 29, 2018 (https://bit.ly/2kIKdu5).

James, Selma. 1975. Sex, Race and Class: The Perspective of Winning. Talgarth: Merlin Press.

Jones, Glen. 2014. "An Introduction to Higher Education in Canada" Pp. 1-38 in Higher Education Across Nations edited by K. Joshi and S. Paivandi. Delhi: B.R. Publishing. Pp. 1-38.

Jones, Miriam and Jennifer Stephen. 1988. “Tempest in a Teapot." Rebel Girls' Rag 2(4): 4-7.

Kaur, Ravneet and Suneela Garg. 2008. "Addressing Domestic Violence Against Women: An Unfinished Agenda." Indian Journal of Community Medicine 33(2): 73-76.

Kashtan, William. 1982. Canada's Party of Socialism. Toronto, ON: Progress Books. 
Kaplan, Temma. 1985. "On the socialist origins of International Women's Day." Feminist Studies 11 (1): 163-171.

Kealey, Linda. 1984. "Canadian Socialism and the Woman Question, 1900-1914." Labour / Le Travail 13 (Spring): 77-100.

Kettle, Martin. 2018. “Where Are All the Revolutionaries of 1968? They're Long Gone." The Guardian, May 17, (https://goo.gl/YmweMB).

Klein, Alice and Wayne Roberts. 1974. “Besieged Innocence: The 'Problem' and Problems of Working Women, Toronto 1896 - 1914" Pp. 223 in Women at Work, Ontario 1850 - 1930 edited by J. Acton, P. Goldsmith, and B. Shepard. Toronto: Canadian Women's Educational Press.

Kilian, Melody. 1968. "Children Are Only Little People, or The Louis Riel University Family Co-Op." Canadian Union of Students. Retrieved June 24, 2019 (https://bit.ly/2YbYkGv).

Kirkconnell, Holly and Sue Craig, Pat McDermott, and Margaret McPhail. 2018. "Organized Working Women (OWW)." Rise Up Feminist Archive. Retrieved November 10, 2018 (https://goo.gl/jmJ7S6).

Kollontai, Alexandra. 2006 [1909]. "The Social Basis of the Women's Question.” Marxist Internet Archive. Retrieved March 10, 2019 (https://goo.gl/zHzAn3).

Krupskaya, Nadezhda. 1936. "Preface: The New Law on Mother and Child." Marxist Internet Archive. Retrieved November 11, 2019 (https://bit.ly/2Q9htYH).

League for Socialist Action. 1968. The Status of Women in Canada. Retrieved November 2, 2018 (https://goo.gl/iheDUX).

Littler, Jo and Mandy Merck, Hilary Wainwright, Nira Yuval-Davis, and Deborah Grayson. 2016. "Feminism and 'the S-word." Soundings 61: 95-112.

Logan, Tricia. 2016. "Indian Residential Schools, Settler Colonialism and Their Narratives in Canadian History." Ph.D., University of London.

Lorenzo, Marie. 1986. "Women and Racism in Toronto: Some Anger and Some Hope." Cayenne 2 (3): 41-43. Retrieved October 26, 2018 (https://goo.gl/T4pAvh).

----. 1985. "Not An Easy Choice: A Feminist Re-examines Abortion." Cayenne 1 (2): 43-44. Retrieved September 22, 2019 (https://bit.ly/2kupZE9).

Lowenberger, Lois. 1983. "IWD: Lip Service to Feminism." Broadside 4 (6): 14. 
Luxemburg, Rosa. 2003 [1912]. "Women's Suffrage and Class Struggle.” Marxist Internet Archive. Retrieved March 10, 2019 (https://goo.gl/sz9Gj6).

----. 2005 [1901]. "The Socialist Crisis in France." Marxist Internet Archive. Retrieved September 25, 2019 (https://bit.ly/2ngNWQj).

Luxton, Meg. 1983. "Two Hands for the Clock: Changing Patterns in the Gendered Division of Labour in the Home." Studies in Political Economy. 12 (Spring): $27-44$.

----. 2001. "Feminism as a Class Act: Working - Class Feminism and the Women's Movement in Canada." Labour/Le Travail 48 (Fall): 63-88.

----. 2015. "Reclaiming Marxist Feminism: A Response." Studies in Political Economy 95 (Spring): 161-172.

----. 2014. "Marxist Feminism and Anti-Capitalism: Reclaiming Our History, Reanimating Our Politics." Studies in Political Economy 94 (Fall): 137-160.

----. 1980. More Than a Labour of Love: Three Generations of Women's Work in the Home. Toronto: Canadian Scholars Press.

Luxton, Meg and June Corman. 1991. "Getting to Work: The Challenge of the Women Back into Stelco Campaign.” Labour / Le Travail 28 (Fall): 148 - 185.

Luxton, Meg and Heather Jon Maroney. 1987. Feminism and Political Economy: Women's Work, Women's Struggles. Toronto: Methuen.

MacDonald, Sherie. 1986. "The Coalition Speech." Cayenne 2(3): 36-37. Retrieved September 24, 2019 (https://bit.ly/2k00Xyc).

Mackay, Ian. 2005. Red, Rebels, and Radicals: Rethinking Canada's Left History. Toronto: Between the Lines.

MacKenzie, David. 2001. Canada's Red Scare 1945-1956. Ottawa: Canadian Historical Association.

MacKinnon, Catharine. 1989. Toward a Feminist Theory of the State. London: Harvard University Press.

Maillé, Chantal and Lena Wängnerud. 1999. "Looking for New Opportunities in Politics: Women's Organizations and the Political Parties in Canada and Sweden" Pp. 184-209 in Women's Organizing and Public Policy in Canada and Sweden edited by L. Briskin and M. Eliasson. Montreal: McGill and Queen's University Press. 
Margolis, Eric. 1998. “Remembering Ukraine's Unknown Holocaust.” Toronto Sun, December 13. Retrieved November 22, 2019 (https://bit.ly/3avREJZ).

Maroney, Heather Jon. 1983. “Feminism at Work.” New Left Review 1(141): 51-71.

Marx, Karl. 1969 [1859]. "Preface to a Contribution to the Critique of Political Economy" Pp. 502-506 in Karl Marx and Friedrich Engels: Selected Works. Moscow: Progress Publishers.

Marx, Karl and Friedrich Engels. 1998 [1845]. The Communist Manifesto. New York: Signet Classics.

----. 1998 [1846]. The German Ideology. New York: Prometheus Books.

----- 1975 [1870]. "Marx to Sigfried Meyer and August Vogt in New York.” Marxist Internet Archive. Retrieved July 16, 2019 (https://bit.ly/1w0604q).

McIntosh, Robert. 1993. "Sweated Labour: Female Needleworkers in Industrialized Canada." Labour / Le Travail 32 (Fall): 105-138.

Millar, Anne. 2011. “Synthesizing Current Research: Women's Higher Education and the World Wars." Strata 3 (September): 24-54. Retrieved November 11, 2019 (https://bit.ly/32Elcjr).

Millett, Kate. 1969. Sexual Politics. New York: Ballantine Books.

McNally, David and Sue Ferguson. 2015. "Socialist Reproduction Beyond Intersectionality: An Interview." Viewpoint Magazine. Retrieved January 17, 2020 [https://bit.ly/2R6uXVF].

Mitchell, Juliet. 1966. “Women: The Longest Revolution.” New Left Review 1(40): 11-37.

Molinaro, Dennis 2011. "Deportation from Canada.” The Canadian Encyclopedia. Retrieved September 16, 2018 from (https://goo.gl/SgegmN).

----. 2018. Deportation from Canada. Ottawa: Canadian Historical Association.

Morris, Cerise. 2006. "Status of Women in Canada." The Canadian Encyclopedia. Retrieved October 21, 2018 (https://goo.gl/K8uqge).

Moscovitch, Allan. 2015. "Welfare State." The Canadian Encyclopedia. Retrieved October 20, 2018 (https://goo.gl/LA5UYc). 
Morton, Peggy. 2005. "Oral History Interview." Alberta Labour History Institute. Retrieved March 31, 2019 (https://goo.gl/syJb3h).

----. 1972. “Woman's Work is Never Done, or, the Production, Maintenance, and Reproduction of Labour Power" [article]. (Box 144, Folder 54). Archives of Ontario, Toronto, Canada.

National Women's Department. N.d. Women Workers in Canadian Industry [report]. Communist Party of Canada. (11C2978). Archives of Ontario, Toronto, Canada.

----. 1931. “The European Conference of Heads of Women's Departments” [report] (11C3072, Box 11, Folder 33). Archives of Ontario, Toronto, Canada.

----. 1931b. National Women's Department Correspondence to WLL [letter]. Communist Party of Canada. (11C3071, Box 11, Folder 33). Archives of Ontario, Toronto, Canada.

Naylor, Tom. 1975. The History of Canadian Business 1867-1914: Industrial Development. Toronto: James Lorimer and Company.

----. 1975. The History of Canadian Business 1867-1914: The Banks and Finance Capital. Toronto: James Lorimer and Company.

Newbigging, Joan. 1968. "The Liberation Struggle." League of Socialist Action. Retrieved November 2, 2018 (https://goo.gl/6YbmSy).

Newton, Janice. 1995. The Feminist Challenge to the Canadian Left, 1900 - 1918. Montreal: McGill-Queen's University Press.

Nicol, Nancy. 1986. “The Struggle for Choice” [video]. Toronto, ON: Intervention Video Inc.

Nolan, Faith. 1987. "Nova Scotian Cultural Activist Delvina Bernard." Our Lives 2(1): 3.

O’Brien, Mary and Freida Forman. “Letters.” Broadside 4 (6): 2.

Ontario Coalition of Abortion Clinics. 1987. "Art in the Struggle." Rebel Girls' Rag. 2 (1): 7. Retrieved January 20, 2020 (https://bit.ly/2G8tjfg).

Ontario Federation of Labour Women's Committee. 1988. "Women Against Mulroney's Trade Deal." Women's Rights Bulletin, January, (https://goo.gl/iHTgGK). 
Ontario Human Rights Commission. N.d. "Timeline of Racial Discrimination and Racial Profiling of Black Persons by the Toronto Policy Service, and OHRC Initiatives Related to Toronto Police." Retrieved November 11, 2019 (https://bit.ly/2X28zgY).

Our Lives. 1988. "Free Trade Agreement and the Garment Industry." Our Lives 2(4): 11. Retrieved October 30, 2018 (https://goo.gl/2xTFhE).

Palmer, Beth. 2012b. "Choices and Compromises: The Abortion Movement in Canada 1969-1988." Ph.D. York University.

Palmer, Bryan. 2012a. Canada's 1960s: The Ironies of Identity in a Rebellious Era. Toronto: Toronto University Press.

----. 2006. "Historical Materialism and the Writing of Canadian History: A Dialectic View." Journal of the Canadian Historical Association 17 (2): 33-60.

-----. 2005. "Maurice Spector, James P. Cannon, and the Origins of Canadian Trotskyism" in Labour / Le Travail 56 (Fall): 91 - 148.

----. 1992. Working Class Experience: Rethinking the History of Canadian Labour, 1800-1991. Toronto: McClelland and Steward Inc.

Parr, Joy. 1990. The Gender of Breadwinners: Women, Men, and Change in Two Industrial Towns 1880 - 1950. Toronto: Toronto University Press.

Patrias, Carmela and Larry Savage. 2012. Union Power: Solidarity and Struggle in Niagara. Edmonton: Athabasca University.

Pelletier, Jacqueline. 1983. "The Future is Now: Women and the Impact of Microtechnology. Women and Technology Committee. Retrieved October 29, 2018 (https://goo.gl/pvVDyA).

Peters, Pauline. 1987. “There's No Racism There.” Our Lives 2 (2-3): 12.

Petrone, Karen. 2004. "Soviet Women's Voices in the Stalin Era." Journal of Women's History 16 (2): 207.

Pierson, Ruth. 1995. "Global Issues" Pp. 360-400 in Canadian Women's Issues Volume 2 edited by M.Cohen and R. Pierson. Toronto: James Lorimer \& Company.

Pompei, Giuliana. 1972. Wages for Housework. Toronto: Canadian Women's Educational Press. 
Porter, Marilyn. 1995. “Call Yourself a Sociologist - And you've Never Even Been Arrested." The Canadian Review of Sociology and Anthropology. 32(4): 415 437.

----. 2013. "In or Against the State: Arts of Activism." Women: ACultural Review. 24 (2): 140-145.

Prentice, Susan. 1986. "Pay Equity: Misguided Strategy for Daycare?" Cayenne 2(4): 7-10. Retrieved October 31, 2018 (https://goo.gl/4adua8).

Rebel Girls' Rag. 1987a. "Rebel Girls Rag: A Forum of Women's Resistance." Rebel Girls' Rag 1(1): 2. Retrieved October 23, 2018 (https://goo.gl/3KcNs6).

----. 1988. “IWDC: Ten Year's of Women's Struggle.” Rebel Girls' Rag 2(3): 2.

----. 1989. "Editorial: The Last Word We Want to Say About the Federal Election." Rebel Girls' Rag 3(2): 2.

----. 1991. “A Forum of Women's Resistance." Rebel Girls Rag 6(1): 1-8.

Rebick, Judy. 2017. "An Oral History of International Women's Day in Toronto." Rabble. Retrieved October 17, 2018 (https://goo.gl/88MfHy).

Rebick, Judy. 2005. Ten Thousand Roses: The Making of a Feminist Revolution. Toronto, ON: Penguin Group.

Rise Up! Feminist Archive. 2018a. "Meet Our Organizing Group." Rise Up! Feminist Archive. Retrieved October 11, 2018 (https://goo.gl/9PmBpp).

----. 2018b. "Ontario Coalition for Abortion Clinics (OCAC)." Rise Up! Feminist Archive. Retrieved July 9, 2019 (https://bit.ly/2XVs3qm).

----. 2018c. “Action Daycare." Rise Up! Feminist Archive. Retrieved July 9, 2019 (https://bit.ly/2LLRhRu).

----. 2019. "Wages for Housework Campaign Bulletin." Rise Up! Feminist Archive. Retrieved July 15, 2019 (https://bit.ly/30BTN0Z).

Revolutionary Marxist Group. 1975. Women's Liberation. Retrieved November 2, 2018 (https://goo.gl/FKN3nF).

Revolutionary Workers' League. 1979. “RWL/LOR Pan Canadian Preconvention Discussion Bulletin." Retrieved September 22, 2019 (https://bit.ly/2m7dFde). 
Richmond, Alexander. 2000. “Stand by Your Man: An Examination of Women's Participation in the Ontario and British Columbia Cooperative Commonwealth Federation 1933 - 1950." M.A., Queen's University.

Robbins, Wendy, Meg Luxton and Margrit Eichler. 2008. Minds of Our Own: Inventing Feminist Scholarship and Women's Studies in Canada and Québec, 1966-76. Waterloo: Wilfred Laurier University Press.

Robert, Allen. 2003. Farm to Factory: A Reinterpretation of the Soviet Industrial Revolution. Princeton: Princeton University Press.

Rodgers, Selena. 2016. "Womanism and Afrocentricity: Understanding the Intersection." Journal of Human Behavior in the Social Environment 27(1-2): 36-47.

Rodimon, Sarah. 2018. "'We Have the Law, We Need the Access!'”: Activism, Access, \& The Social Organization of Abortion in New Brunswick." Ph.D., Carleton University.

Rousseau, Christina. 2016. "The Dividing Power of the Wage: Housework as Social Subversion." Atlantis 37(2): 238-252.

Rowbotham, Sheila, Lynne Segal, and Hilary Wainwright. 1981. Beyond the Fragments: Feminism and the Making of Socialism. London: Merlin Press.

----. 2013. Beyond the Fragments: Feminism and the Making of Socialism. London: Merlin Press.

Royal Canadian Mounted Police. 1934. “No. 711. Weekly Summary Report on Revolutionary Organizations and Agitators in Canada." Retrieve October 13, 2016 (https://goo.gl/LHOZuI).

----. 1934. "No. 718. Weekly Summary Report on Revolutionary Organizations and Agitators in Canada." Retrieve October 13, 2016 (https://goo.gl/LHOZuI).

----. 1934. "No. 761. Weekly Summary Report on Revolutionary Organizations and Agitators in Canada." Retrieve October 13, 2016 (https://goo.gl/G4P2FA).

Sangster, Joan. 2010a. Transforming Labour: Women and Work in Post-war Canada. Toronto: University of Toronto Press.

----. 2010b. "Radical Ruptures: Feminism, Labor, and the Left in the Long Sixties in Canada." American Review of Canadian Studies 40(1): 1-21.

----. 1989. Dreams of Equality: Women on the Canadian Left, 1920 - 1950.

Toronto: University of Toronto Press. 
-----. 2000. "Feminist and the Making of Canadian Working-Class History: Exploring Past, Present, and Future." Labour / Le Travail 46 (Fall): 127-165.

Sayers, Janet and Mary Evans and Nanneke Redcliff. 2009. Engels Revisited: Feminist Essays. New York: Routledge.

Segal, Lynne. 1990. Slow Motion: Changing Masculinities, Changing Men. London: Virago Press.

Sethna, Christabelle Laura and Steve Hewitt. 2018. Just Watch Us: RCMP Surveillance of the Women's Movement in Cold War Canada. London: McGill-Queen's University Press.

Siegelbaum, Lewis and Andrei Sokolov. 2004. Stalinism as a Way of Life. London: Yale University Press.

Sinclair, Niigaanwewidam James and Sharon Dainard. 2016. "Sixties Scoop." The Canadian Encyclopedia. Retrieved January 17, 2020 [https://bit.ly/30WZCWF].

Smith, Dorothy. 1985. "Socialist Network Growing." Cayenne 1(2): 3-5.

----. 1984. "Socialist Women and the Peace Movement." IWDC Newsletter 6(3): 3 -5. Retrieved October 26, 2018 (https://goo.gl/VZduAV).

Smith, Sharon. 1997. "Engels and the Origin of Women's Oppression." International Socialist Review 2 (Fall). Retrieved September 16, 2017 (https://goo.gl/H4XJez).

Spector, Maurice. 1928. "Statement to Canadian Party." Marxist Internet Archive. Retrieved November 12, 2019 (https://bit.ly/2KfTL9s).

Stalin, Joseph. 2008 [1926]. "Concerning Questions of Leninism: Dedicated to the Leningrad Organisation of the C.P.S.U. (B.)." Marxist Internet Archive. Retrieved March 23, 2019 (https://goo.gl/C2KbEs).

Statistics Canada. 2018. “Unionization Rates Falling." Retrieved November 3, 2019 (https://bit.ly/33mUUUd).

-----. 2019. "Employment by Industry, Monthly, Seasonally Adjusted (x1000)." Retrieved November 3, 2019 (https://bit.ly/2JN8o3L).

Steedman, Mercedes. 1994. "The Promise: Communist Organizing in the Needle Trades, the Dressmakers' Campaign. 1928-1937." Labour / Le Travail 34 (Fall): 37-73. 
Steffen, Robert. 1988. “A-V Reference Shelf." Labor Studies Journal 13(1): 68-69. Retrieved October 29, 2018 (https://goo.gl/4264N4).

Stettner, Shannon Lea. 2011. "Women and Abortion in English Canada: Public Debates and Political Participation, 1959-70.” Ph.D., York University.

Stephen, Jennifer and Miriam Jones. 1989. “The Big NAC Attack.” Rebel Girls' Rag $3(4): 2$.

Stephen, Jennifer. 1989. “What is a Rebel Girl?” Rebel Girls' Rag 3 (4): 3. Retrieved October 25, 2018 (https://goo.gl/FCwzZe).

----. 1988. “What is to Be Done With the NDP." Rebel Girls' Rag 2 (2): 4-5.

Steinecker, Sandy. 1985. "IWD: Alphabet Soup." Broadside 6 (1): 8-9. Retrieved October 18, 2018 (https://goo.gl/H8c71A).

----. 1984. “Talking to Socialist feminists.” IWDC Newsletter. 6(4): 14-15. Retrieved December 7, 2018 (https://bit.ly/32eRFxK).

Stote, Karen. 2012. "The Coercive Sterilization of Aboriginal Women in Canada." American Indian Culture and Research Journal 36 (3): 117-150.

Struthers, James. 2013. “The Great Depression in Canada." The Canadian Encyclopedia. Retrieved November 10, 2019 (https:bit.ly/2rvblzr).

Sugiman, Pam. 1994. Labour's Dilemma: The Gender Politics of Auto Workers in Canada 1937 - 1970. Toronto: University of Toronto Press.

The Canada Gazette. 1940. [Order in Council]. Library and Archives Canada. Retrieved November 11, 2019 (https://bit.ly/2qlw4zs).

Thompson, Tony. 1975. "'The Development of Class in Canada in the Twentieth Century:' A Critique." Retrieved October 30, 2019 (https://bit.ly/2NsKA5Z).

Toronto Black Women's Collective. 1986a. “Statement of the Black Women's Collective." Cayenne 2(3): 30-31. Retrieved October 26, 2018 (https://goo.gl/aH7DBV).

----. 1986b. “Sisterhood Must Be Struggled For.” Our Lives 1(1).

Toronto Wages for Housework Committee. 1977. "Editorial.” Wages for Housework Campaign Bulletin 2(1): 3. 
Trotsky, Leon. 1996 [1937]. The Revolution Betrayed: What is the Soviet Union and Where is it Going? Retrieved December 7, 2018 (https://bit.ly/32cBRvn).

----. 1938. "The USSR and Problems with the Transitional Epoch." Retrieved November 3, 2019 (https://bit.ly/2NCBJ1W).

United Nations Human Rights Committee. 2015. "Concluding Observations on the Sixth Periodic Report of Canada." Retrieved May 15, 2019 (https://bit.ly/2CgIEK5).

United Steelworkers. N.d. “A Brief History of 'Women in Steel.'” United Steelworkers. Retrieved November 3, 2019 (https://bit.ly/2qhLTw0).

Van Ree, Eric. 1998. “Socialism in One Country: A Reassessment.” Studies in East European Thought 50 (2): 77-117.

Veterans Affairs Canada. 2017. "Canada Remembers Women on the Home Front." Retrieved November 10, 2019 (https://bit.ly/2X26UIn).

Vickers, Jill, Pauline Rankin, and Christine Appelle. 1993. Politics As If Women Mattered: A Political Analysis of the National Action Committee on the Status of Women. Toronto: University of Toronto Press.

Vogel, Lisa. 1989. Marxism and the Oppression of Women Toward a Unitary Theory. New Brunswick: Rutgers University Press.

Wages for Housework Committee. 1977. Wages for Housework Bulletin 2 (1): 1-4.

----. 1977b. “International Campaign News.” Wages for Housework Bulletin 1 (3): 4.

Wainwright, Hilary. 2003. Reclaim the State: Experiments in Popular Democracy. London: Verso.

-----. 2015. "Why I Became a Socialist feminist." Jacobin. Retrieved May 15, 2019 (https://bit.ly/30kpHjj).

Wasserlein, Jane. 1980. “'An Arrow Aimed at the Heart' The Vancouver Women's Caucus and the Abortion Caravan 1969 - 1971." B.A. (Honours), University of British Columbia.

Watkins, Mel. 2018. "The New Language of Resource Exploitation: From Staples Theory to Extraction Empire." Retrieved September 11, 2019 (https://bit.ly/2lJLxNg). 
Weir, Lorna. 1987. "Women and the State: A Conference for Feminist Activists." Feminist Review 26(1): 93-105.

Weisleder, Barry. 2018. "Canadian Trotskyism and the Legacy of James P. Cannon." Left Voice. Retrieved November 11, 2019 (https://bit.ly/2Q5P05M).

Whetmore, Elizabeth Ann Wilson. 2014. "Empowering Women-A Series of Articles About the Surge in and Fragmentation of Mid-20th-Century American Feminist Theory: Article 1: Radical Notions." Sage 4(3): 1-12. Retrieved August 12, 2019 (https://bit.ly/2Ksr7lQ).

Whitaker, Reginald, Gregory Kealey, and Andrew Parnaby. 2012. Political Policing in Canada from the Fenians to Fortress America. Toronto: Toronto University Press.

Wilkinson, Bruce. 2006. "Free Trade." Canadian Encyclopedia. Retrieved October 30, 2018 (https://goo.gl/rd5ZcB).

Willis, Ellen. 1984. "Radical Feminism and Feminist Radicalism." Social Text 9(10): 91-118.

Windham, Lane. Knocking on Labour's Door: Union Organizing in the 1970s and the Roots of a New Economic Divide. Chapel Hill: The University of North Carolina Press.

Wirick, Ronald. 2006. "Keynesian Economics." The Canadian Encyclopedia. Retrieved October 20, 2018. (https://goo.gl/zFBkwE).

Wright, Cindy. 1982. “Coalition Politics: A Workshop.” IWDC 4 (4): 3.

Young, Iris. 1980. "Socialist Feminism and the Limits of Dual Systems Theory" Socialist Review 10(2): 169-88.

Young Worker. 1976. "Soviet Youth Barred from Canada." Young Worker (July -August). 